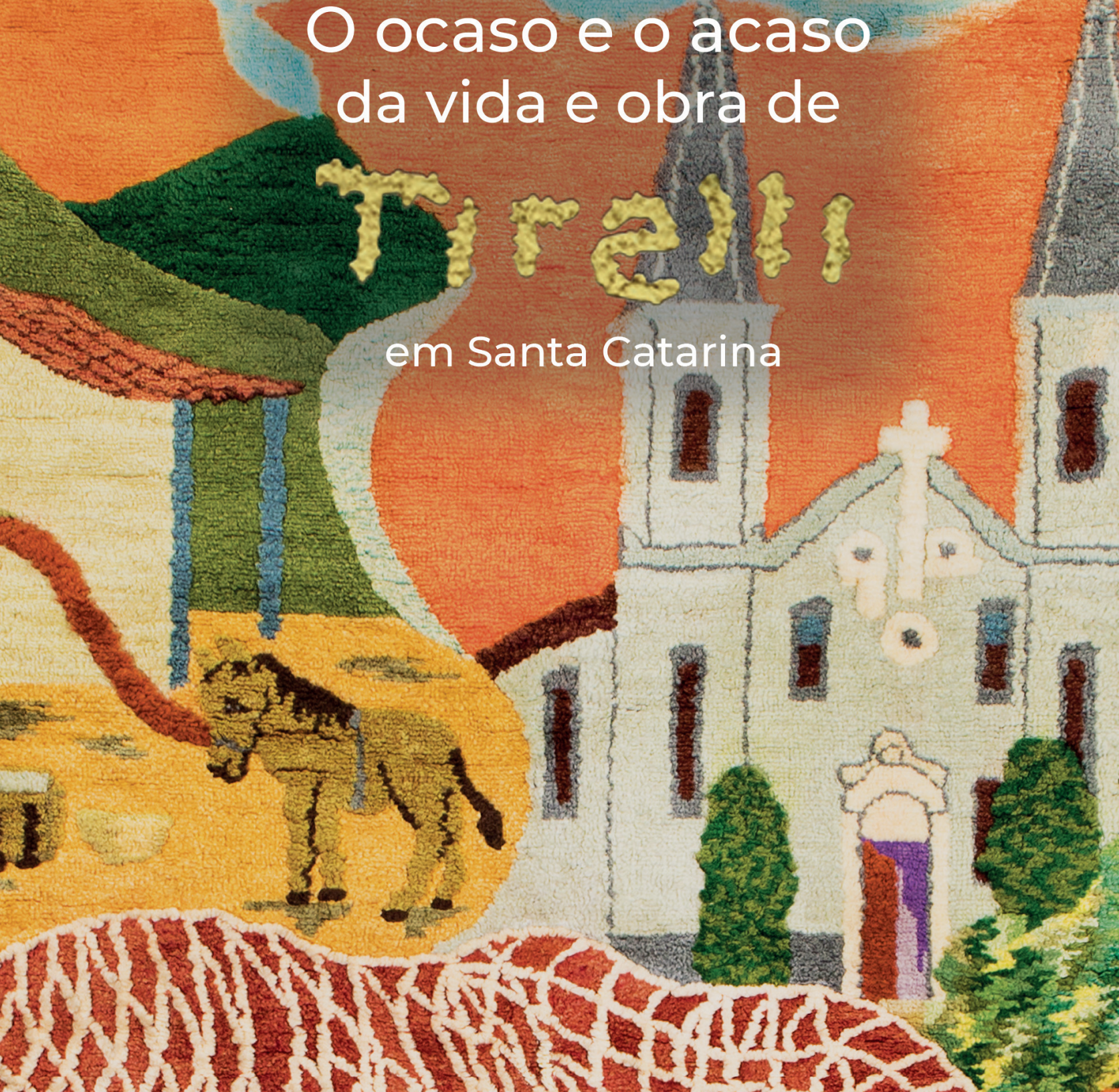

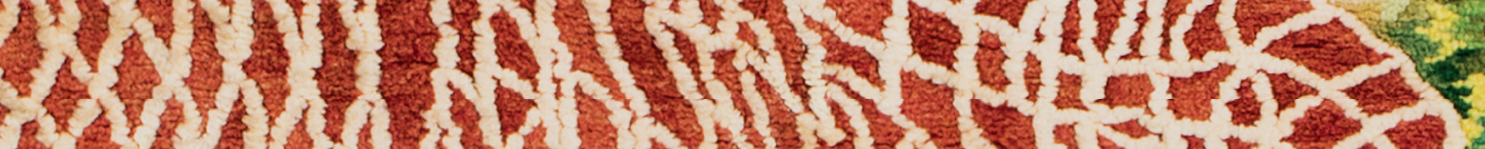

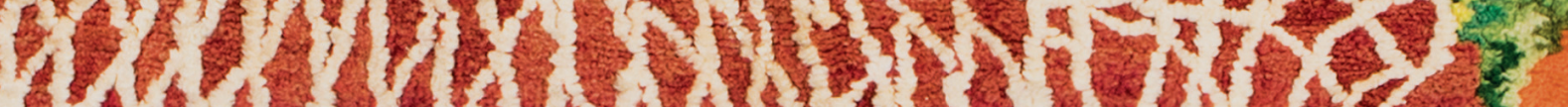

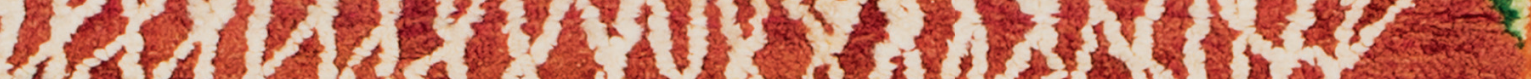

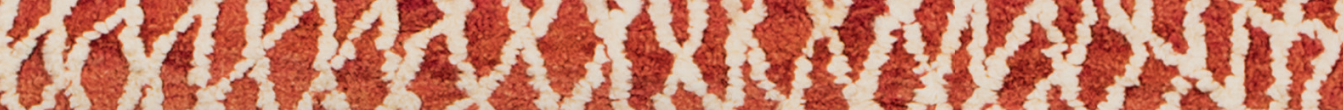

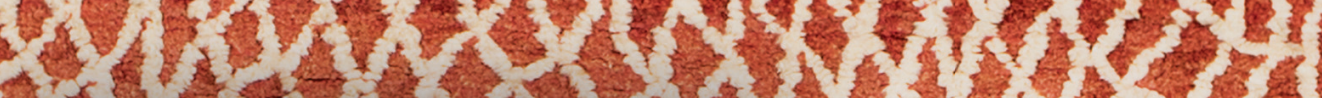

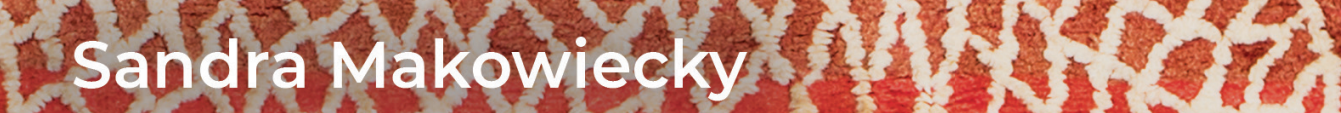
.

2O EDIORA

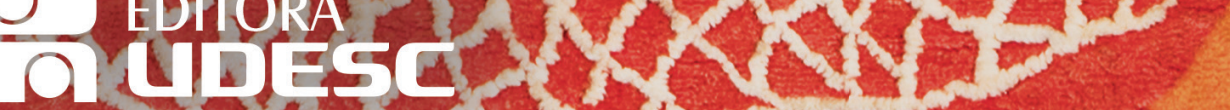







\section{O ocaso e o acaso da vida e obra de TH: El| em Santa Catarina}

Sandra Makowiecky OD EDITORA 


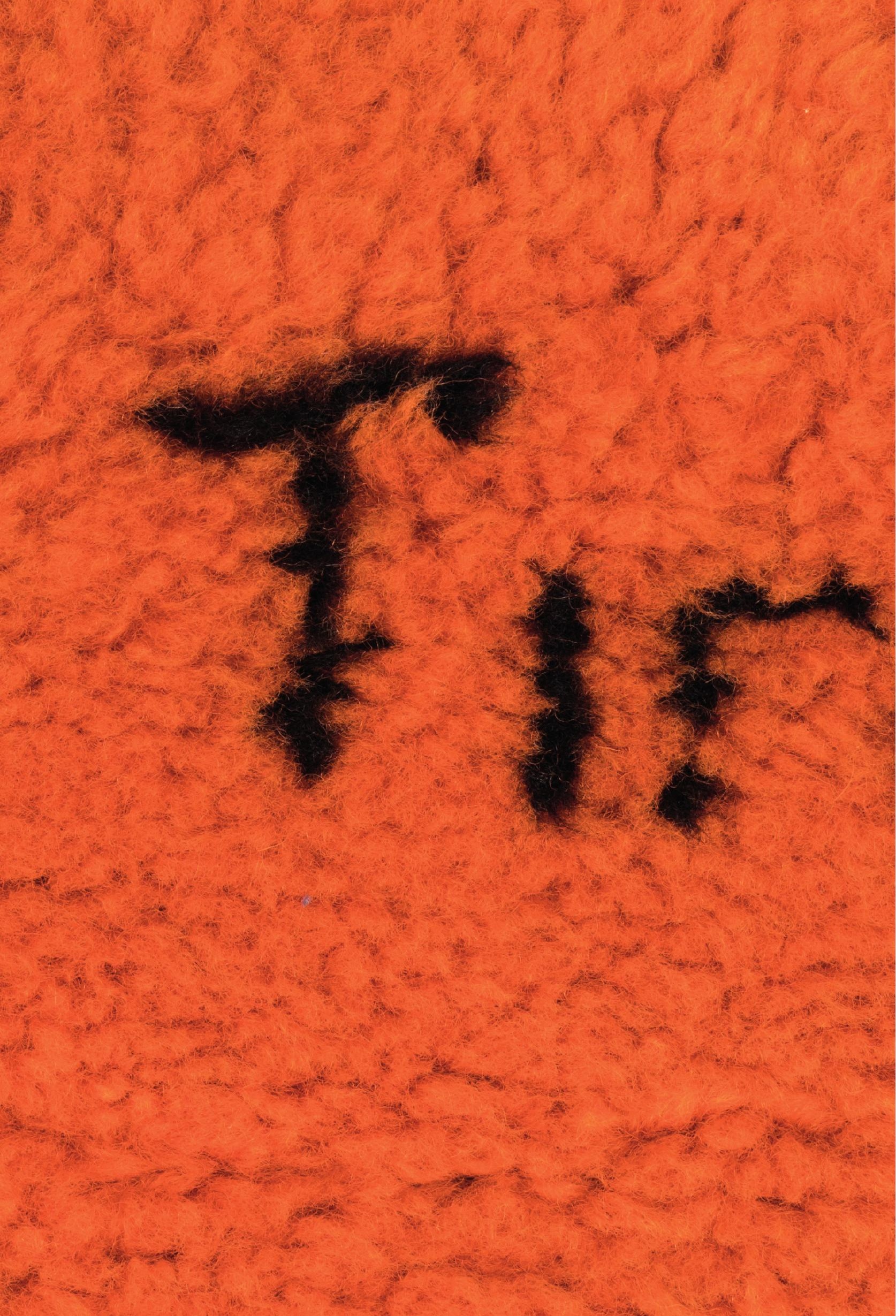




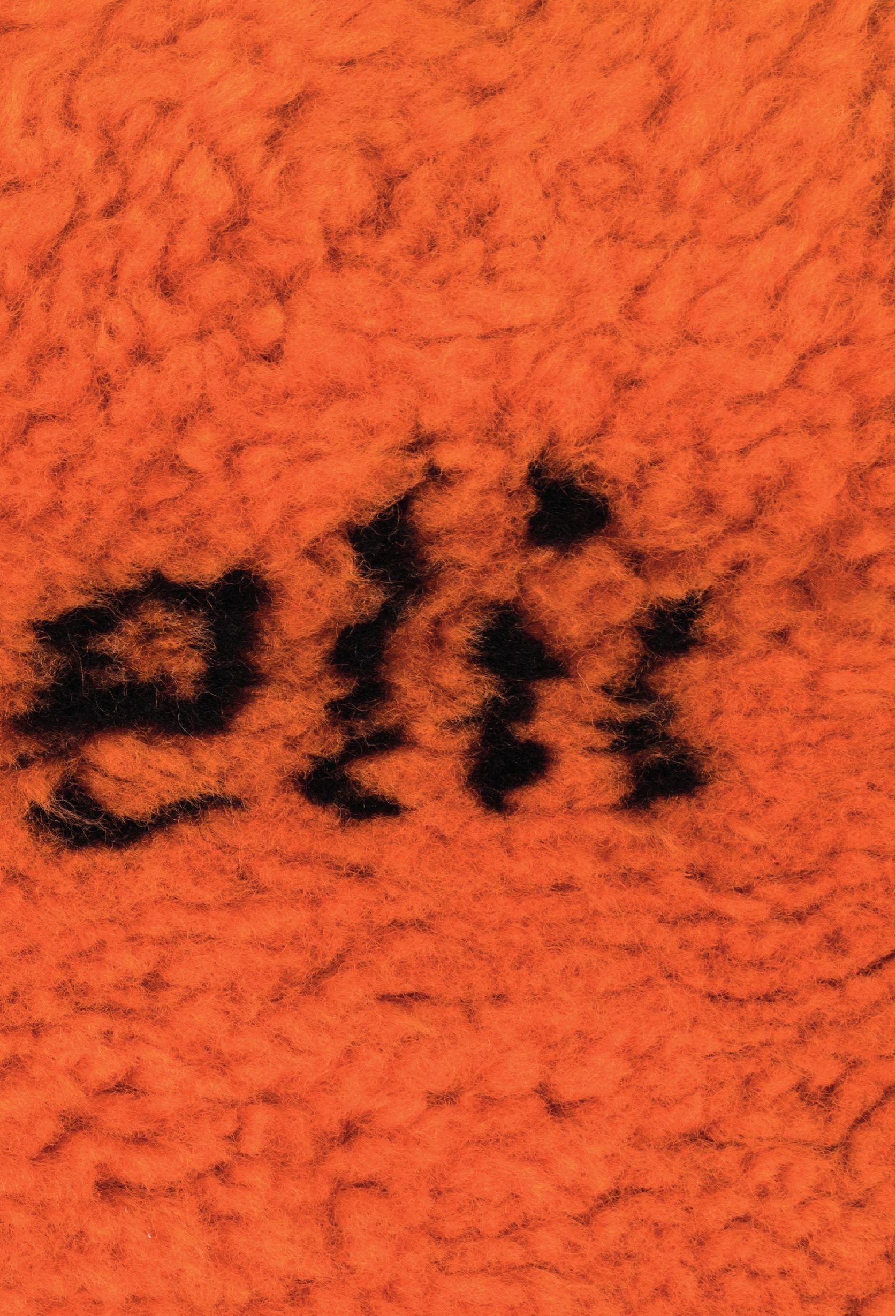




\section{Título}

O ocaso e o acaso da vida e obra de Almir Tirelli em Santa Catarina

\section{Autora}

Sandra Makowiecky

Revisão de texto

Zulma Neves de Amorim Borges

\section{Design Gráfico}

Andrey Parmigiani

\section{Dados Internacionais de Catalogação na Publicação (CIP) (Câmara Brasileira do Livro, SP, Brasil)}

015 O ocaso e o acaso da vida e obra de Almir Tirelli em Santa Catarina / Sandra Makowiecky; revisão de texto de Zulma Neves de Amorim Borges; design gráfico de Andrey Parmigiani - Florianópolis: UDESC, 2021.

96 p. : il.; $29 \mathrm{~cm}$

ISBN-e: 978-65-88565-24-7

ISBN: 978-65-88565-23-0

Referências: p. 80-82.

1. Arte - Santa Catarina. 2. Artistas - Santa Catarina. 3. Biografia. 4. Pintura - Santa Catarina. 5. Pintura - Apreciação. I. Borges, Zulma Neves de Amorim. II. Parmigiani, Andrey.

DOI:

Versão digital: 10.5965/978-65-88565-24-7.

CDD: 709.8164 - 20. ed.

Ficha catalográfica elaborada pela Bibliotecária Alice de A. B. Vazquez CRB 14/865

Biblioteca da UDESC

(C) das fotografias: fizeram-se todos os esforços possíveis para identificar e reconhecer os autores das reproduções. Qualquer erro ou omissão será revisto em reedição futura. (c) dos textos: seus autores. Os textos dos artigos refletem as opiniões dos seus autores e não são necessariamente compartilhadas pelos editores.

A reprodução de imagens de obras nesta publicação tem o caráter pedagógico e científico amparado pelos limites do direito de autor no art. 46 da Lei no 9610/1998, entre elas as previstas no inciso III (a citação em livros, jornais, revistas ou qualquer outro meio de comunicação, de passagens de qualquer obra, para fins de estudo, crítica ou polêmica, na medida justificada para o fim a atingir, indicando-se o nome do autor e a origem da obra), sendo toda reprodução realizada com amparo legal do regime geral de direito de autor no Brasil. 


\section{UNIVERSIDADE DO ESTADO DE SANTA CATARINA - UDESC \\ Reitor}

Dilmar Baretta

\section{Vice-Reitor}

Luiz Antonio Ferreira Coelho

\section{Pró-Reitora de Administração}

Marilha dos Santos

Pró-Reitor de Planejamento

Márcio Metzener

\section{Pró-Reitor de Ensino}

Nério Amboni

Pró-Reitor de Extensão, Cultura e Comunidade (Proex)

Mayco Morais Nunes

Pró-Reitora de Pesquisa e Pós-Graduação

Letícia Sequinatto

Coordenadora do Museu da Escola Catarinense (MESC)

Sandra Makowiecky

\section{EDITORA UDESC - CONSELHO EDITORIAL}

Marcia Silveira Kroeff - Presidente

Christiane Dalla Costa - Secretária

Avanilde Kemczinski (titular) e Ana Borges de Azevedo (suplente) - CCT

Delcio Pereira (titular) e Fernanda Hansch Beuren (suplente) - CEPLAN

Fabiano Maury Raupp (titular) e Leonardo Secchi (suplente) - ESAG

Fernando Coelho (titular) e Luciana Rossato (suplente) - FAED

Gilmar Moraes Santos (titular) e Alexandro Andrade (suplente) - CEFID

Giovanni Lemos de Mello (titular) e Micheli Cristina Thomas (suplente) - CERES

Jordan Paulesky Juliani (titular) e Cleia Demetrio Pereira (suplente) - CEAD

Marilei Kroetz (titular) e Paulo Roberto da Cunha (suplente) - CEAVI

Roseli Lopes da Costa Bortoluzzi (titular) e Veraldo Liesenberg (suplente) - CAV

Samira Kauchakje (titular) e Luis Fernando Lamas de Oliveira (suplente) - CESFI

Sandra Regina Rech (titular) e Guilherme Antonio Sauerbronn de Barros (suplente) - CEART

William Campo Meschial (titular) e Alexandre Tadeu Paulino (suplente) - CEO

Esta publicação recebeu apoio financeiro da UDESC.

Realização: Museu da Escola Catarinense (MESC)

REALIZAÇÃO

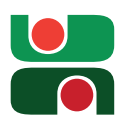

UDESC UNIVERSIDADE DO ESTADO DE SANTA CATARINA

\section{APOIO}

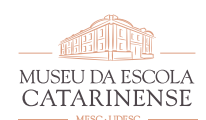

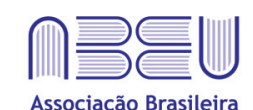

Associação Brasileira das Editoras Universitárias

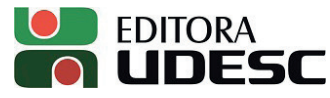




\section{SUMÁRIO}

Introdução

01

04

Vamos começar do começo

14

Exposição em Homenagem a Almir Tirelli

no MASC, em 1988

16

Sobre a técnica da tapeçaria

18

As tapeçarias de Tirelli no aeroporto de Florianópolis e seus episódios

19

Episódio Numero 1 - Ano de 2009, tapeçarias desaparecem

21

Os mecenas das tapeçarias

22

Episódio número 2 - As obras da construção do Floripa Airport

Episódio número 3 - Floripa Ganha novo aeroporto

25

Episódio número 4 - Fundação Catarinense de Cultura entra em cena

26

Episódio número 5 - Um convite

27

Os painéis: O tríptico de Almir Tirelli 
Painel número 2 do tríptico

32

A relação do painel número 2 de Tirelli com a história

38

Painel número 3 do tríptico

39

Outras obras do artista e relação com outros artistas e obras

60

Episódio número 6 - A montagem

da exposição em 2021

68

Para concluir e tentando pensar

em possíveis novos episódios

77

Por um legado

80

Referências bibliográficas

83

Anexos

ANEXO A - Material que pertence aos documentos do MASC referentes à exposição de 1988 denominada "Almir Tirelli, 20 anos de Florianópolis"

90

ANEXO B - Lei número 9.095, de 20 de maio de 1993, que concede Título de Cidadão Catarinense ao Senhor "Almir Tirelli Dias"

91

ANEXO C - Ficha diagnóstico do estado de conservação das tapeçarias de Almir Tirelli. Fonte: Marcelo do Amaral - FCC. Ano 2020 



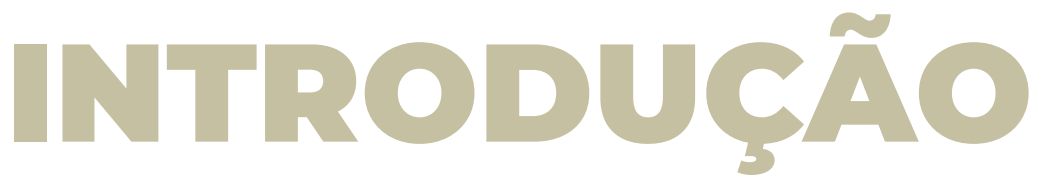

Para iniciar esta apresentação acerca de Almir Tirelli (1926-2012) (Figura1), lembremos as palavras célebres do prefácio de Marcel Schowb em Vidas imaginárias:

A ciência histórica nos deixa na incerteza sobre os indivíduos. Ela só nos revela os pontos pelos quais eles foram anexados às ações gerais. [...] A arte está no oposto das ideias gerais, só descreve o individual, só deseja o único. Ela não classifica, ela desclassifica. (SCHOWB, 2004, p. 53).

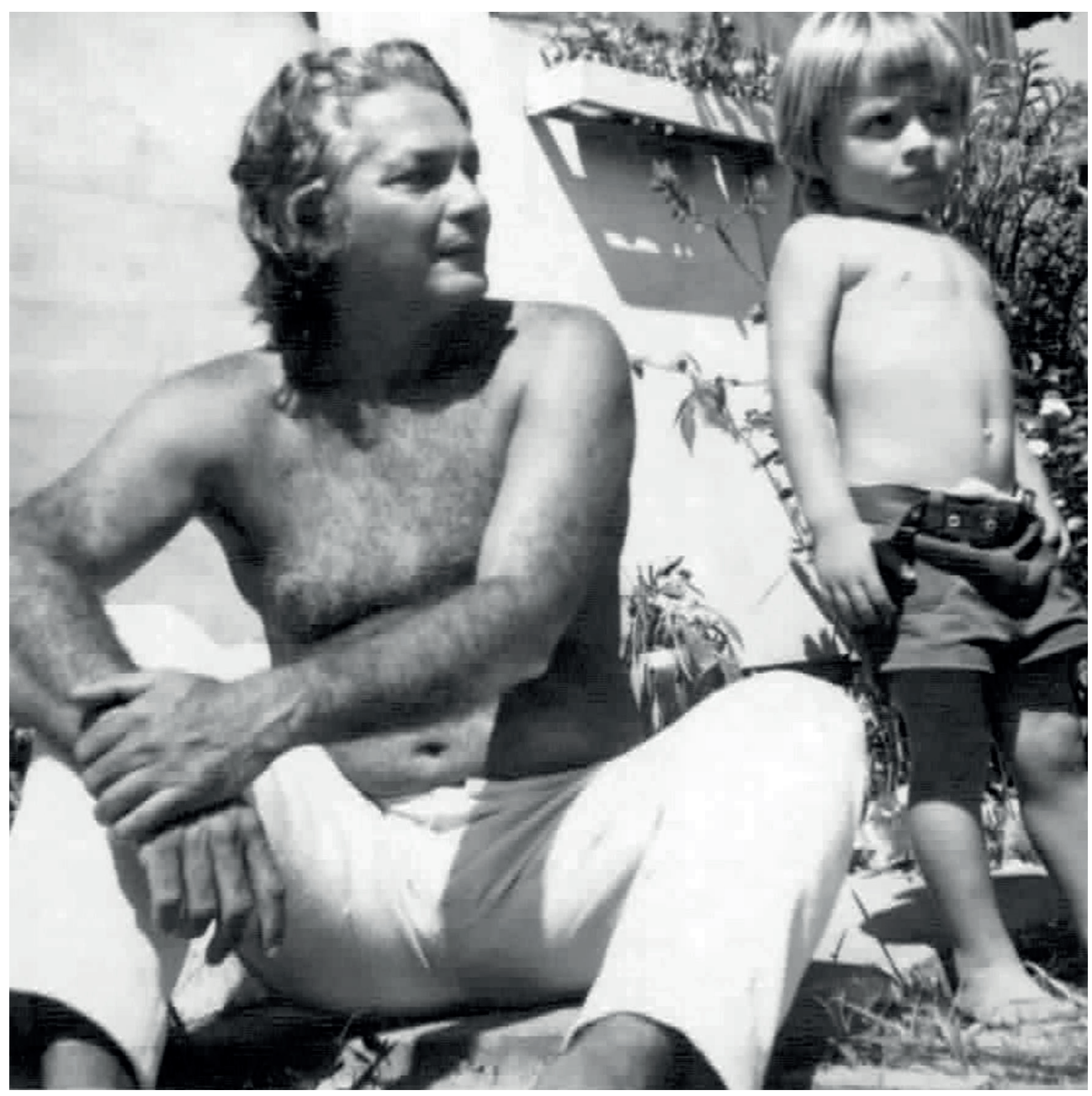

Figura 1 - O artista Almir Tirelli na casa 06 na Concasa da Ponte do Imaruim. Fonte: Projeto Memória Palhocense. 
Como então analisar um artista e sua obra, a partir de poucos fragmentos, fato inusitado para mim, através de uma pesquisa praticamente realizada por meio do Google e redes sociais? Quantas incertezas, apagamentos e reaparições desse artista ocorreram ao longo do tempo! Quanta dificuldade em reunir e tentar ter uma ideia de sua trajetória. Por esse motivo, tentou-se registraroquefoilocalizado, dando-se primazia afatosefalas documentadas.

Recorri a alguns teóricos para me expressar melhor, neste início do texto. Em Nos Mínimos Detalhes, Alain de Botton pergunta até quanto um biógrafo deve saber para poder bem realizar a tarefa a que se propõe. Evidente que não se trata de uma biografia, mas, na falta de dados, urge fazer uma certa reconstrução destes. O autor salienta que, "quando relembramos o passado, imagens muito menos tangíveis nos assaltam" (BOTTON, 2000, p. 95), e as partes que julgamos significativas só o são geralmente para nós. Eis o perigo. Vivemos hoje uma fase em que, mais do que nunca, a biografia encontra-se no centro das preocupações dos historiadores, mas ela assume claramente suas ambiguidades. Em alguns casos, recorre-se a ela a fim de sublinhar a irredutibilidade dos indivíduos e de seus comportamentos a sistemas normativos gerais, em nome da experiência vivida; em outros, em contrapartida, ela é percebida como - lugar ideal para experimentar a validade das hipóteses científicas concernentes às práticas e ao funcionamento efetivo das leis e das regras sociais (LEVI, 2006). Reafirmo que não se trata de uma biografia.

Todavia, gosto muito desta citação de Walter Benjamin:

Método deste trabalho: montagem literária. Não tenho nada a dizer. Somente a mostrar. Não surrupiarei coisas valiosas, nem me apropriarei de formulações espirituosas. Porém, os farrapos, os resíduos, não quero inventariá-los, e sim fazer-lhes justiça da única maneira possível: utilizando-os. (BENJAMIN, 2009, N, 1ª, p. 7).

Sabemos que é impossível uma reconstituição total da memória, pois ela opera selecionando aquilo que deseja. A impossibilidade do acesso cria barreiras para a perpetuação da memória, trabalhando para o extermínio desta. Optamos por abordar o passado e a memória como um fluxo que está sujeito a saltos e desvios em que o imponderável e o contingente não cessam de se cruzarem, mas aqui os riscos de apagamento precisam ser encarados e contornados, senão em todo, pelo menos no que nos cabe e até onde podemos. Nesses espaços, alguns detalhes da vida de obra de Almir Tirelli serão destacados, no pouco que foi encontrado.

Por mais rápida que se torne a comunicação entre as pessoas, graças 
ao mundo virtual, as cartas escritas desde tempos imemoriais bem como as obras de arte são testemunhos de descobertas científicas, de guerras, do cotidiano dos povos, dos laços de família, das ligações amorosas e da memória. Muitos desses documentos ficam guardados, longe de todos, escondidos, onde aqueles que sonham com o passado encerram seus segredos. Remexer nesses cantos adormecidos, seja uma parede de casa de família, seja uma pasta com desenhos, seja um armário caseiro, sejam arquivos de bibliotecas com suas pastas amareladas, significa, no desenlace da fita ou do cordão que os ata, tocar no universo íntimo, fazer tilintar lembranças e imagens. Não são poucos os arquivos que, adormecidos, estão prestes a serem acordados e revelarem o que guardam. Onde estão os arquivos de Almir Tirelli? Onde está seu famoso Livro de Tombo?

No universo da arte, obras recebedoras de muita importância e apreço contrastam com tantas outras ao nosso redor que recebem muito menos atenção. Onde se instala, na história, a obra de arte que não alcançou determinado brilho e destaque em seu tempo? Como continuar existindo sem esses cuidados e atenção? O que se sabe da história desses artistas que vivem à margem e que se expressaram em tinta nas muitas telas que se encontram hoje empoeiradas em algum salão, sujas e desbotadas, postas de lado em algum acervo ou apenas desviadas e esquecidas? O que se sabe daqueles artistas que mereceram uma parede de um gabinete importante, dos que conseguem, ainda hoje, participar de exposições, coleções, citações ou algum reconhecimento? Quantos são os que possuem hoje alguma preocupação na perpetuação de seu nome e legado para as gerações vindouras? A arte que segue em seu discreto existir em nossas paredes, murais, edifícios públicos, nos raros catálogos de acervos, em alguns poucos websites e nas mãos de colecionadores, particulares, artistas e famílias de artistas... é tudo o que temos. No confronto entre dois postulados - um completamente imerso no campo tradicional da História e das Belas Artes, outro claramente disseminado num âmbito de resistência - abre-se um debate crucial para nossa cultura: até quando e de que maneira é possível lembrar o passado imediato e quais seriam as estratégias efetivas da arte para manter viva e ativa a memória de nossa arte para gerações futuras?

O ocaso de Almir Tirelli, esse aparente declínio de um astro no horizonte, no lado em que o sol se põe e desaparece, e o acaso, a imprevisibilidade e as incertezas que rondaram as tapeçarias de Almir Tirelli que estavam no aeroporto serão aqui expostos. 


\section{VAMOS COMECAR DO COMEÇO}

No jornal Bom Dia, de agosto de 2018 (O ESPAÇO..., 2018), consta que Almir Tirelli era filho de um engenheiro mecânico italiano que imigrou para o Brasil no século passado. Quando o navio fez escala em São Luís, foi convidado a assumir a manutenção dos equipamentos fabris do parque industrial local, que começava a desenvolver-se. Aceitou, desembarcou e ficou. Ali o italiano Tirelli constituiu família, e foi onde Almir Tirelli nasceu. Artesão, tapeceiro, pintor e desenhista autodidata, escultor e ator de cinema, frequentou a Escola Preparatória de Cadetes, de Fortaleza, no Ceará, e, por dois anos, o curso de Química Industrial no Machenzie College, em São Paulo. Realizou cursos de Gerência e Administração e Relações Públicas no SENAC, Rio de Janeiro; Chefia e Liderança e Relações Humanas no Trabalho e Previdência Social na Fundação Getúlio Vargas.

O texto datado de 28 de novembro de 2018, do Projeto Memória Palhocense (O ARTISTA, 2018), menciona que o artista plástico Almir Tirelli Dias marcou época nas décadas de 60 e 70 em Palhoça, quando levou o nome do município para o País e a várias partes do mundo por meio de sua arte de tapeçaria e pintura. Mas, antes disso, exerceu cargos de chefia no Instituto Nacional de Assistência Médica da Previdência Social (Inamps), do Rio de Janeiro, São Paulo e Belo Horizonte/MG, pedindo exoneração em 1970, para dedicar-se inteiramente à arte. Sua primeira exposição foi em 1970, individual, na Universidade Federal de Santa Catarina, que deve ter uma tapeçaria de Almir Tirelli em seus acervos.

O artista plástico autodidata nasceu em São Luiz, no Maranhão, em 1926. Casado com Maria Stella Viana Tirelli Dias, com quem teve três filhos: Marcílio Dias (in memorian), Arlete e Luiz Alberto. Residiu em São Paulo, Rio de Janeiro, Belo Horizonte e Florianópolis, antes de chegar em Palhoça em 1966, quando morou na casa n. ${ }^{\circ} 06$ da Concasa, na Ponte do Imaruim. Ali teve intensa vida comunitária e deu início aos trabalhos de pintura, desenhos e tapeçaria (Figura 2). 


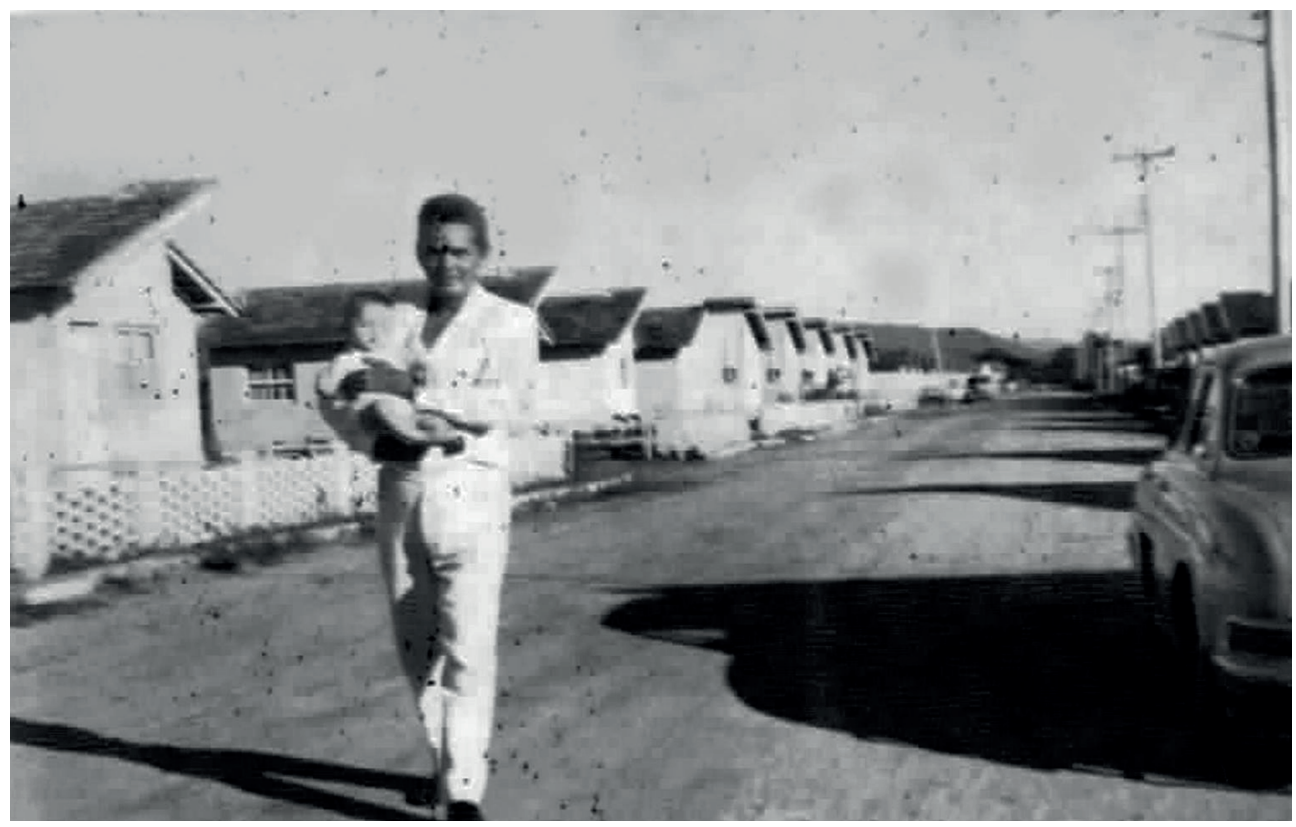

Figura 2 - Tirelli na Concasa - Ponte do Imaruim, onde veio morar em 1966. Fonte: Projeto Memória Palhocense.

Em 1973, adquiriu um terreno na Rua Caetano Silveira de Mattos, ao lado da loja Beth Bordados, no centro da cidade, onde construiu uma casa e seu ateliê e onde residiu até 1980 (Figura 3).

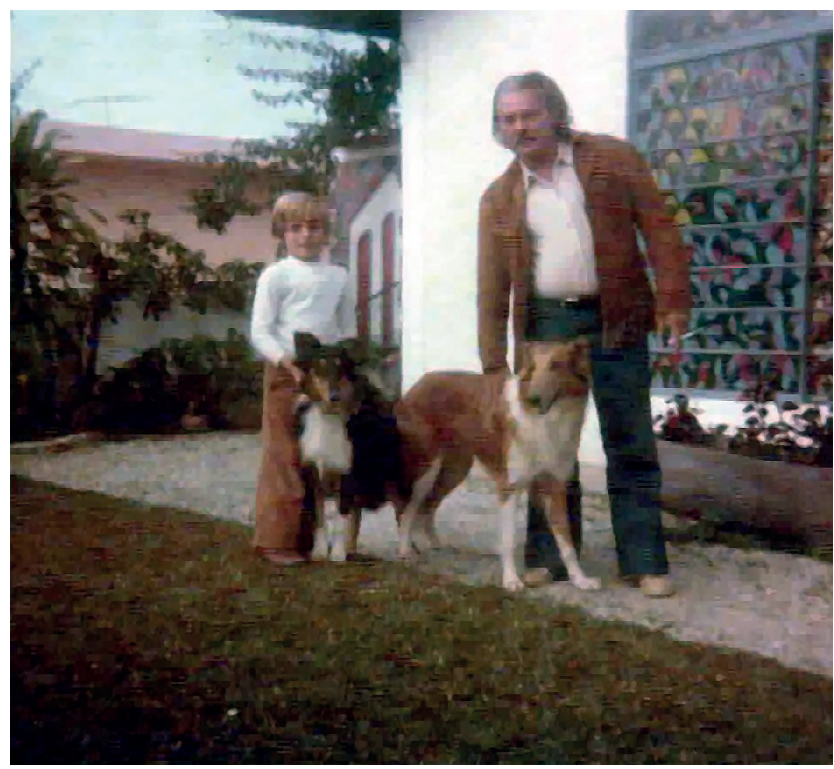

Figura 3 - Tirelli com o filho Carlos Alberto, na sua casa e ateliê na Rua Caetano Silveira de Mattos, onde residiu até 1980. Fonte: Projeto Memória Palhocense. 
Recebia ali incontáveis visitas oficiais do Brasil e do exterior, como também turistas de todos os estados do Brasil, da Argentina, Uruguai, Paraguai, Portugal, Alemanha, Israel, França, Grécia, entre outros locais. Suas obras correm o mundo e estão presentes em 2.707 acervos particulares do Brasil e em 17 países. Almir Tirelli deixou registradas no Livro de Tombo 4.628 obras (O ARTISTA..., 2018), que levaram o nome de Palhoça para todos os cantos do mundo. Realizou 32 exposições no Brasil e no exterior e é detentor de inúmeros prêmios e condecorações. Em 1991, realizou uma exposição e lançamento do Álbum Histórico das Fortalezas da Ilha, Fortaleza de Santa Cruz de Anhatomirim, (texto e gravura) (Figura 4).

O artista utilizava, em suas telas, que tinham como tema o Brasil colonial, suas edificações, costumes e folclore, tinta acrílica, e nas tapeçarias, o ponto smirna com lã (dados de 2018).

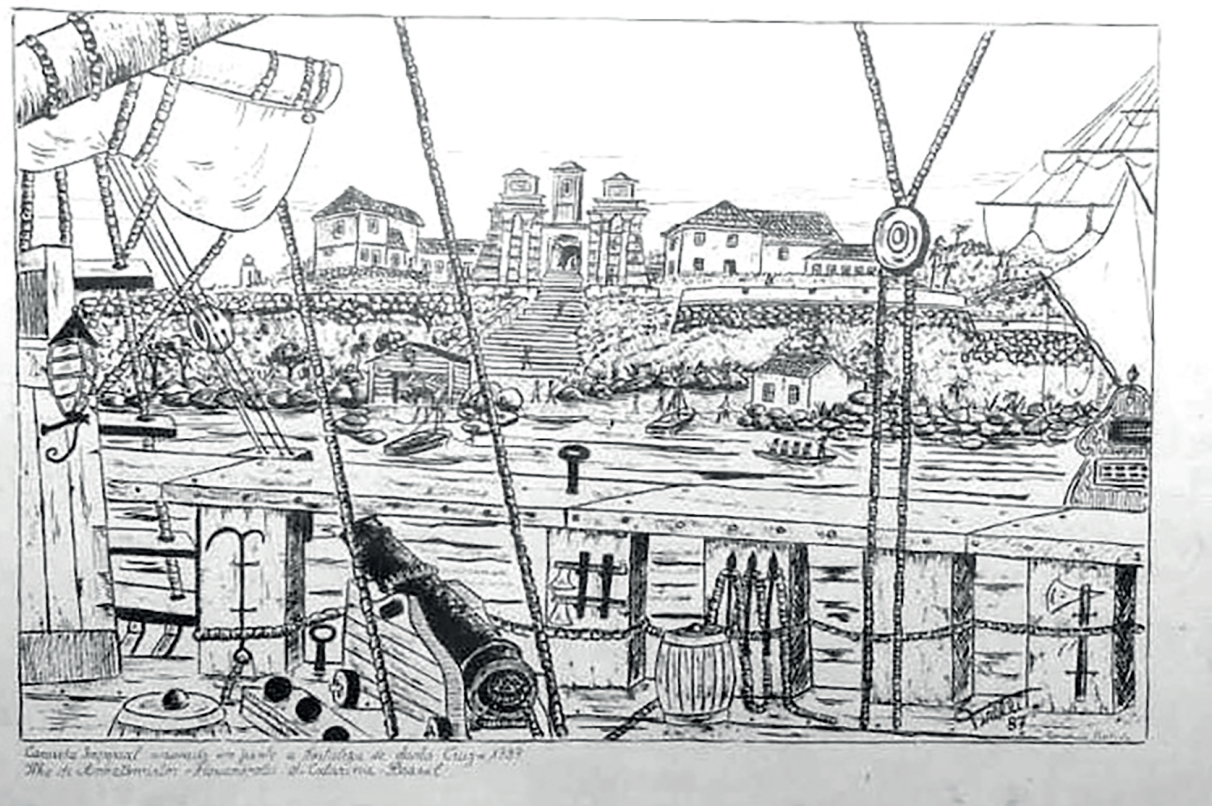

Figura 4 - Almir Tirelli. Gravura da série Album Histórico das Fortalezas da Ilha, Fortaleza de Santa Cruz de Anhatomirim. 1987. Dimensões totais, 44,5 x 33,5 cm. Alguns exemplares já foram arrematados em importantes leilões do País.

Fonte: Projeto Memória Palhocence

O primeiro cartão-postal de Palhoça (Figura 5), editado pela Prefeitura Municipal, em 1975, na administração do prefeito Odílio José de Souza, que teve como título: Palhoça: A rainha do litoral catarinense, homenageava 
o artista e trazia algumas de suas obras em tapeçaria, que retratavam aspectos arquitetônicos e culturais da cidade.

Em 1980, Tirelli mudou-se para a Lagoa da Conceição, onde construiu casa e ateliê (Figura 6)..

Lembro vagamente que mencionaram o fato do desgosto de Almir Tirelli e sua saída de Florianópolis. Almir Tirelli não conseguiu colocar a estátua de cimento de um surfista sobre as pedras do costão da praia da Joaquina. A esse respeito, saiu uma nota em jornal. Dizia o texto:

O que o artista Almir Tirelli não conseguiu em Florianópolis, levando-o, magoado, a deixar a cidade e asilar-se em Minas Gerais - colocar estátua de cimento de um surfista sobre as pedras do costão da praia da Joaquina - a também artista Rita Machado conseguiu, sem problemas, no costão das Pedras Brancas e Negras da praia de Itajubá, em Barra Velha. A estátua, instalada semana passada, com 1,90 metro de altura e moldada em pedra, ferro e concreto, homenageia o surfista Ivan Roberto Marquart, que morreu no local em maio de 1985.

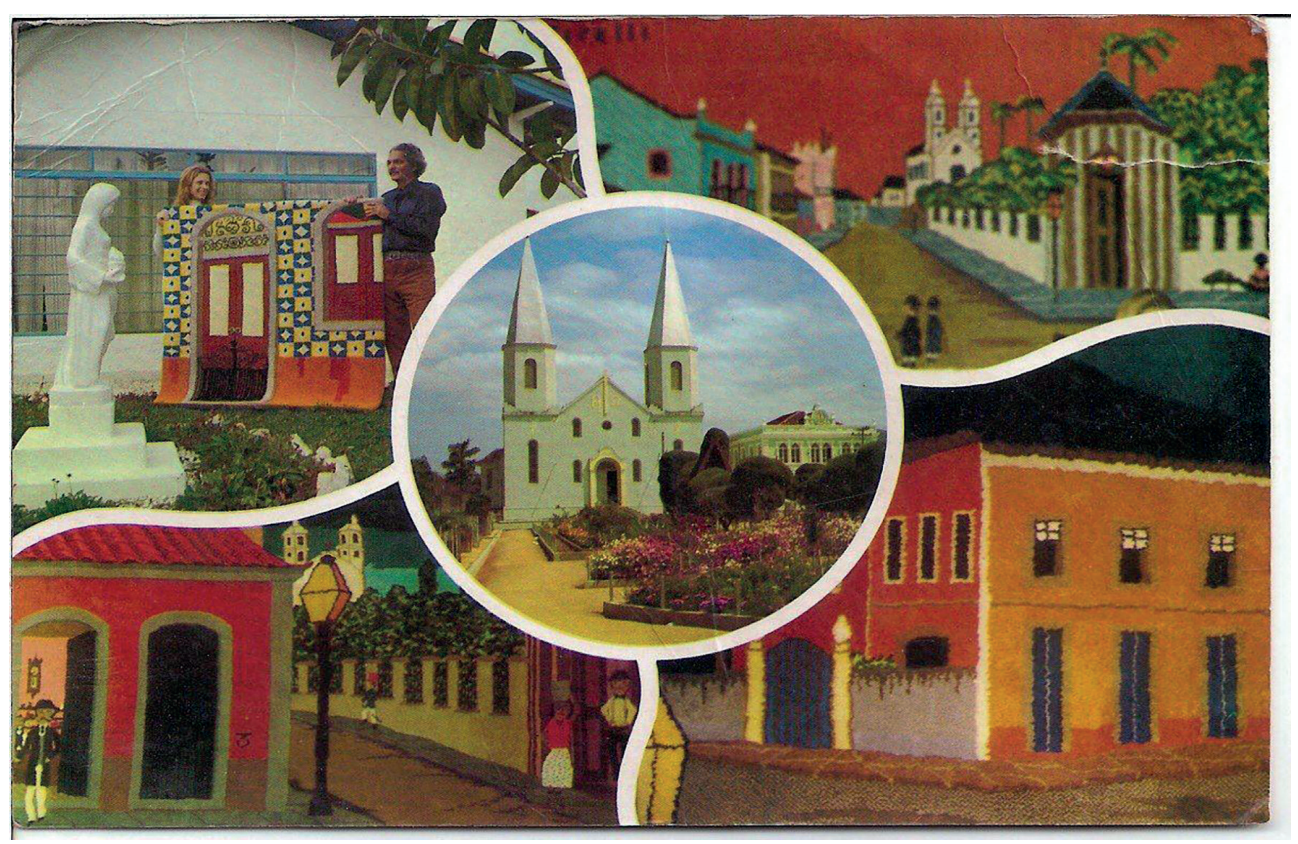

Figura 5 - Cartão postal de 1975 com obras do Tirelli e Maria Stella Tirelli. Fonte: Projeto Memória Palhocense. 


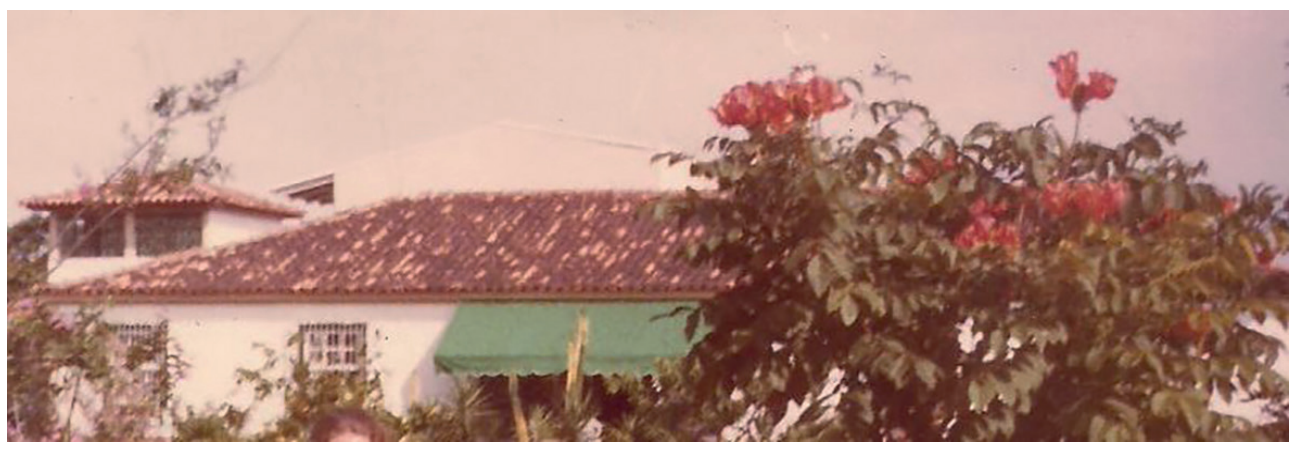

Figura 6 - Tirelli e casa da Lagoa da Conceição, onde construiu casa e ateliê. Fonte: Projeto Memória Memória Palhocence.

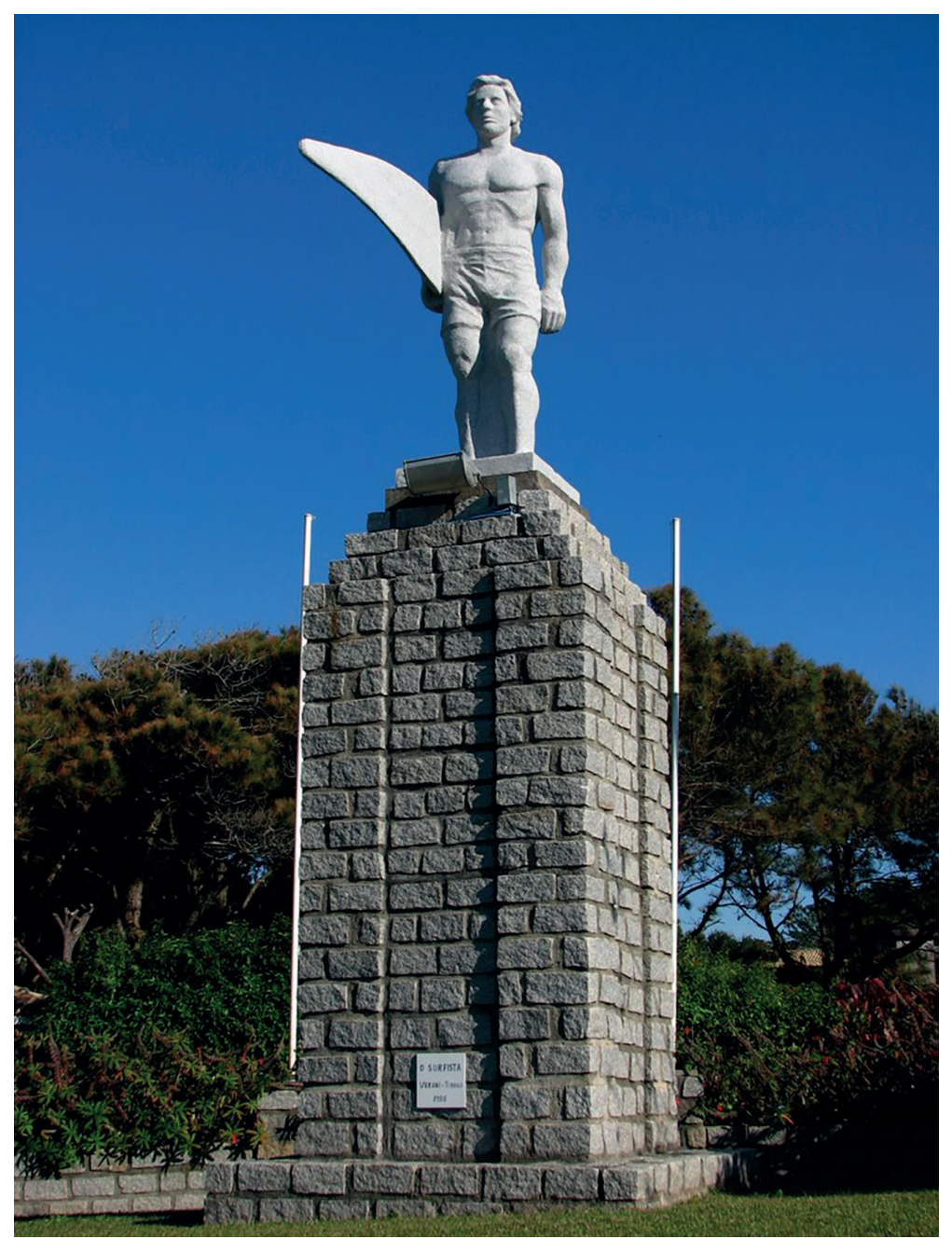

Figura 7 - Almir Tirelli e Plínio Verani. 1995. Estátua do Surfista - Praia Mole. Fonte: Hotel Praia Mole Cabanas. 
A estátua do surfista (Figura 7), feita por Almir Tirelli, foi construída para o costão da Praia da Joaquina em homenagem a todos os surfistas. No dia da sua colocação com helicóptero, o projeto foi proibido pela Prefeitura, e a estátua ficou na frente da casa do artista por quase 10 anos, até que foi comprada pelo hotel Praia Mole Cabanas.

O resto é história, não tenho como confirmar tal fato, mas a estátua tornou-se um importante cartão-postal da Praia Mole e de Florianópolis e saúda diariamente todos os surfistas que tornam nossa praia ainda mais bela e mais viva.

Dessa Forma, Tirelli viveu na Lagoa da Conceição até o ano 2000, quando resolveu mudar-se para a cidade histórica de Tiradentes (MG). Passado alguns anos, sentindo falta do mar, em 2008, mudou-se para Guarapari (Espírito Santo), aos 82 anos de idade. De vez em quando, visitava a Ilha. Nem os amigos maranhenses de Tirelli, em São Luís, entendiam seu afastamento voluntário de Florianópolis, terra onde ele "se sentia acolhido como filho". Faleceu em 2012, aos 86 anos de idade, em Guarapari, e onde sua esposa Maria Stella e o filho Luiz Alberto ainda residem (2021).

Almir Tirelli residiu em vários estados, mas ficou durante um longo período em Florianópolis, em Palhoça e depois na Lagoa da Conceição, com sua esposa Maria Stella. Desenvolveu uma profícua produção artística, pintando telas com temas da antiga Desterro e tecendo belíssimas tapeçarias em ponto smirna, diz a reportagem. Todavia, olhando um catálogo de sua exposição realizada no Museu de Arte de Santa Catarina, em 1988 (retornaremos a ela depois), constam técnicas como "Smirna", "Smirna com relevos", "mista em partes baixas" e "meio ponto". Não entendo essas especificidades, mas podem ser úteis para estudiosos da tapeçaria.

Com Almir Tirelli (1926 - 2012) e Pedro Paulo Vechietti (1933 - 1993), a tapeçaria assumiu um lugar de expressão artística no Estado. Sua pintura e sua tapeçaria identificaram-se tanto com Santa Catarina que, aqui, poucos sabiam da verdadeira naturalidade do artista. Era identificado como filho da terra. Em 1987, a Câmara Municipal de Florianópolis concedeu-Ihe o título de Cidadão Honorário. Em 1993, foi reconhecido com o Título de Cidadão Catarinense na Assembleia Legislativa de Santa Catarina (ALESC), pela Lei n. ${ }^{\circ}$ 9095, de 20 de maio de 1993, Procedência: Júlio Garcia, Natureza: PL 084/93; DO: 14.697, de 28 de maio de 1993 (ANEXO B). O governador do Estado era Vilson Pedro Kleinubing.

No seu livro de registros dos trabalhos que criou, até 1993 constavam 
1.419 obras, e as tapeçarias alcançavam a expressiva marca de 1.050, segundo relato de Eliézer Moreira Filho, do Portal Arte no Maranhão, que, naquele ano, visitou Tirelli em Florianópolis. Eliézer tem um grande acervo de obras de artistas maranhenses (O ESPAÇO..., 2018).

Almir Tirelli deixou um legado de obras de arte em vários prédios públicos da cidade. Em seu ateliê, havia muitas pinturas a óleo de grandes dimensões, que reproduziam paisagens urbanas de Florianópolis na época colonial. O artista tem obras espalhadas em vários países e ganhou inúmeros prêmios e condecorações. 


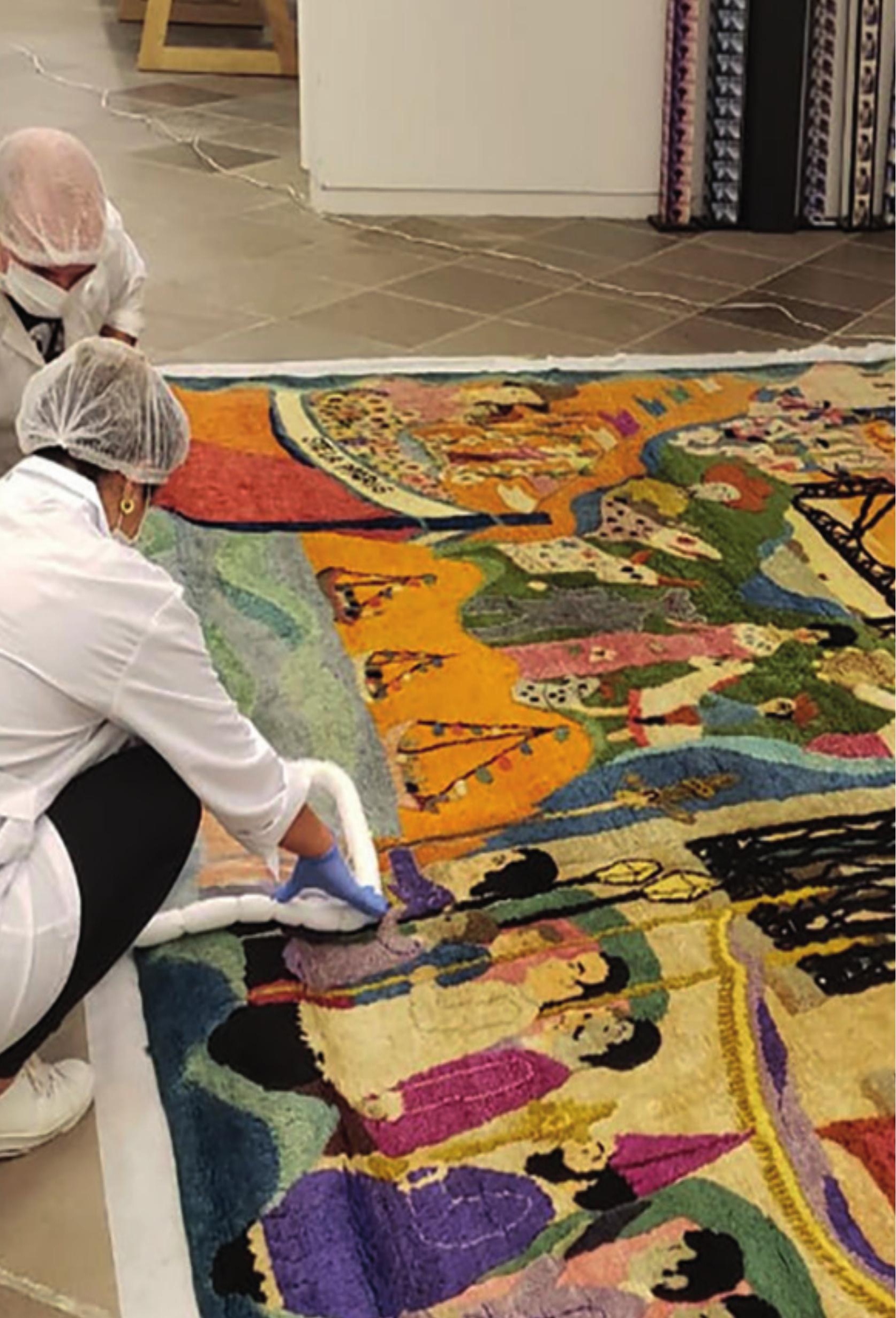


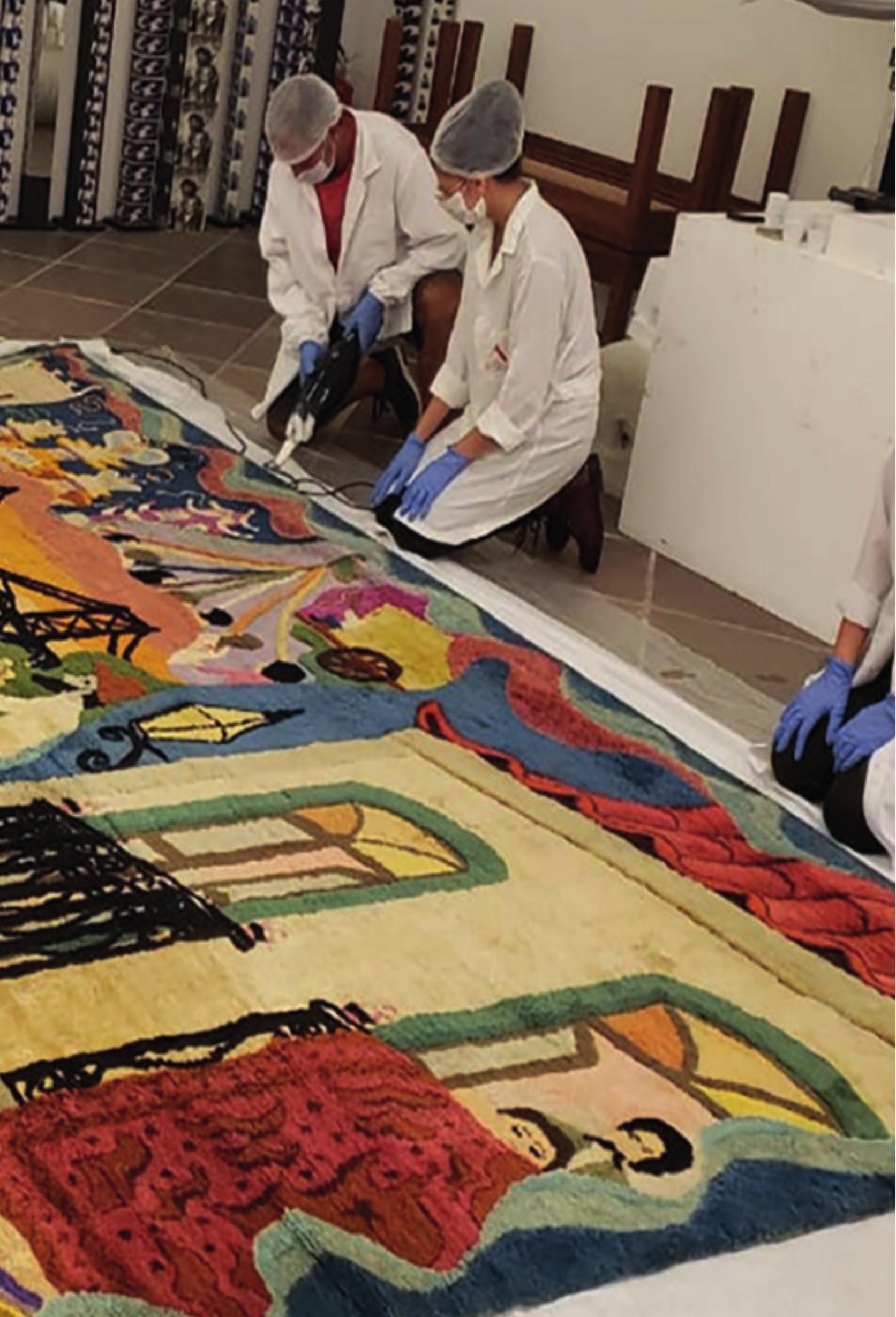




\section{EXPOSICC̃̃O EM HOMENAGEM A ALMIR TIRELLLI NO MASC, EM

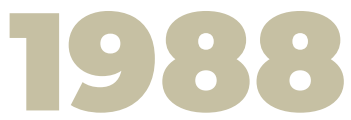

Em 3 de março de 1988, no Museu de Arte de Santa Catarina (MASC), no ciclo de março, aconteceu a abertura da exposição do artista - "Almir Tirelli, 20 anos de Florianópolis" - individual de tapeçarias, em homenagem ao artista maranhense, que adotou a ilha em 1966, quando se transferiu para Santa Catarina. Foram expostas 40 tapeçarias, todas em posse de colecionadores que cederam as obras para a exposição. As obras mostravam a marca do Brasil Colônia que ele conheceu no Norte, tanto quanto as imagens da Florianópolis antiga - aquela cidade que Tirelli conheceu quando chegou em Florianópolis e retratou com perfeição nas telas de grandes dimensões que elaborou. Consta ainda que o público poderia apreciar uma obra em homenagem às artes catarinenses, em um trabalho que teve como motivação uma obra de Victor Meirelles. A exposição foi preparada em uma montagem-surpresa, feita ao artista, por sua esposa Maria Stella Viana Tirelli Dias e funcionários do MASC (ANEXO A).

Também ocorreu uma coletiva de trabalhos de 10 artistas catarinenses, que incluiu quadros de Martinho de Haro, Sílvio Pléticos, Meyer Filho, Rodrigo de Haro, Loly Hosterno, Janga, Vera Sabino, Max Moura, Vecchietti e Antonio Mir, emprestados da coleção do Banco do Estado de Santa Catarina (BESC).

Na temporada do ciclo de março, também festejou-se a doação de uma escultura de Helena Montenegro ao Museu, pela própria artista, que foi instalada no jardim interno na entrada do MASC, em concreto, onde se encontra até hoje. Com essa informação, fui olhar o acervo virtual do MASC e, salvo melhor juízo, não encontrei obra de Tirelli no acervo. 
Ao rever as anotações, temos que seu livro tombo, em 1993, mencionava 1.419 obras (O ESPAÇO..., 2018), e as tapeçarias alcançavam a expressiva marca de 1.050. No ano de 2018, foram registradas 4.628 obras (O ARTISTA..., 2018). Nosso principal Museu, que acolheu uma homenagem/retrospectiva, não possui nenhuma obra? Não à toa esses apagamentos ocorrem. Qual o melhor lugar para manter-se uma obra viva? Onde foram parar ou estão essas tapeçarias? Por que nunca mais as vimos?

Todavia, em material que recebi do Museu de Arte de Santa Catarina, percebemos dados impressionantes da difusão de obras de Almir Tirelli, que constam nos anexos deste trabalho. Os anexos mostram dados sobre 597 obras produzidas até julho de 1980, apontando alguns locais onde essas obras encontravam-se, tanto em acervos nacionais como no exterior (nomes como Pelé e Roberto Carlos aparecem na listagem). Impressionam a dispersão, o volume e distribuição desses tapetes mundo afora. A última notícia sobre o Livro de Tombo de Almir Tirelli menciona 4.628 obras, como já exposto. De 597 para 4.628 obras, existe um intervalo de 4.000 obras. Se apenas os dados sobre as 597 já são expressivos, fico a imaginar o restante. Mas em se tratando de Almir Tirelli, sempre a imaginar, pois são os tais ocasos. 


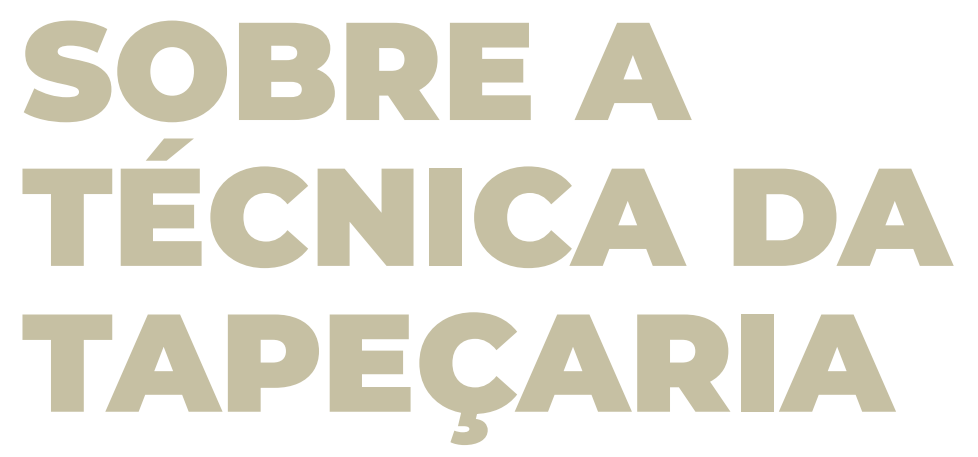

Vamos discorrer brevemente sobre tapeçarias, por ser a técnica mais desenvolvida por Almir Tirelli. Tapeçaria é uma técnica manual de tecelagem que produz o tecido por meio do entrelaçamento de fios obtidos de fibras flexíveis, como lã ou algodão. O uso de fios coloridos e várias técnicas de entrelaçamento permite a criação de figuras e imagens.

Nos últimos anos, a tapeçaria voltou a ser objeto de desejo e está presente em muitos projetos contemporâneos de decoração. Além da tapeçaria clássica, é possível utilizar peças que utilizam outras técnicas, como o macramê, o looping, smirna (ou esmirna), crochê, tufado, franjas, entre outras.

Na recente onda de valorização do trabalho manual, jovens entusiastas mundo afora exploram diferentes técnicas e acabamentos para enfeitar paredes com verdadeiras obras de arte.

A origem da tapeçaria não é definida com exatidão, pois a técnica surgiu em vários locais do mundo aproximadamente no mesmo período. Seus registros mais evidentes na Antiguidade vêm do Egito, mas sabe-se que povos que habitaram a Mesopotâmia, Grécia, Roma, Pérsia, Índia e China também praticavam a tapeçaria.

Durante a Idade Média, a tapeçaria assumiu grande importância como elemento decorativo de igrejas e castelos medievais e também ajudava no conforto térmico desses locais. Outra função da tapeçaria na Idade Média era, por meio dos desenhos, "narrar" cenas históricas ou bíblicas.

A partir do século XIV, a tapeçaria bordada cede lugar para a tecida. Já no final do século $X V$, com as mudanças estéticas promovidas pelo Renascimento, a pintura começa a exercer mais influência sobre a tapeçaria. Foram criadas manufaturas de tapeçaria, dedicadas à produção exclusiva para a nobreza. Nesse período, a tapeçaria francesa ganha destaque no mundo, principalmente por causa da famosa manufatura dos Gobelins. 
No século XX, os ateliês tradicionais de tapeçaria começaram a produzir peças criadas por artistas, como Raoul Dufy (1877-1953), Georges Braque (1882-1963), Pablo Picasso (1881-1973), Joán Miró (1893-1983) e Henri Matisse (1869-1954). A escola de arte Bauhaus foi outra grande difusora.

É possível notar como a tapeçaria é uma arte que evoluiu ao longo do tempo, sempre se renovando de acordo com os estilos e técnicas vigentes em cada período da história.

Almir Tirelli trabalhava com a técnica chamada smirna. Os tapetes cuja técnica de confecção levam esse nome são feitos com fios de lã nos quais tramam-se nós em uma tela especial chamada talagarça. Podem ter relevos ou não. Almir Tirelli desenvolveu a smirna com relevos. Também executou o que chamava de "mista em pontos baixos". Existem muitos pontos, no entanto, o mais utilizado é o meio ponto, também conhecido como petit point. É um ponto simples e rápido de executar, que consiste numa diagonal. Pode-se bordar na vertical, de cima para baixo, ou na horizontal, da direita para a esquerda, técnica que Almir Tirelli também executou (Figura 8).

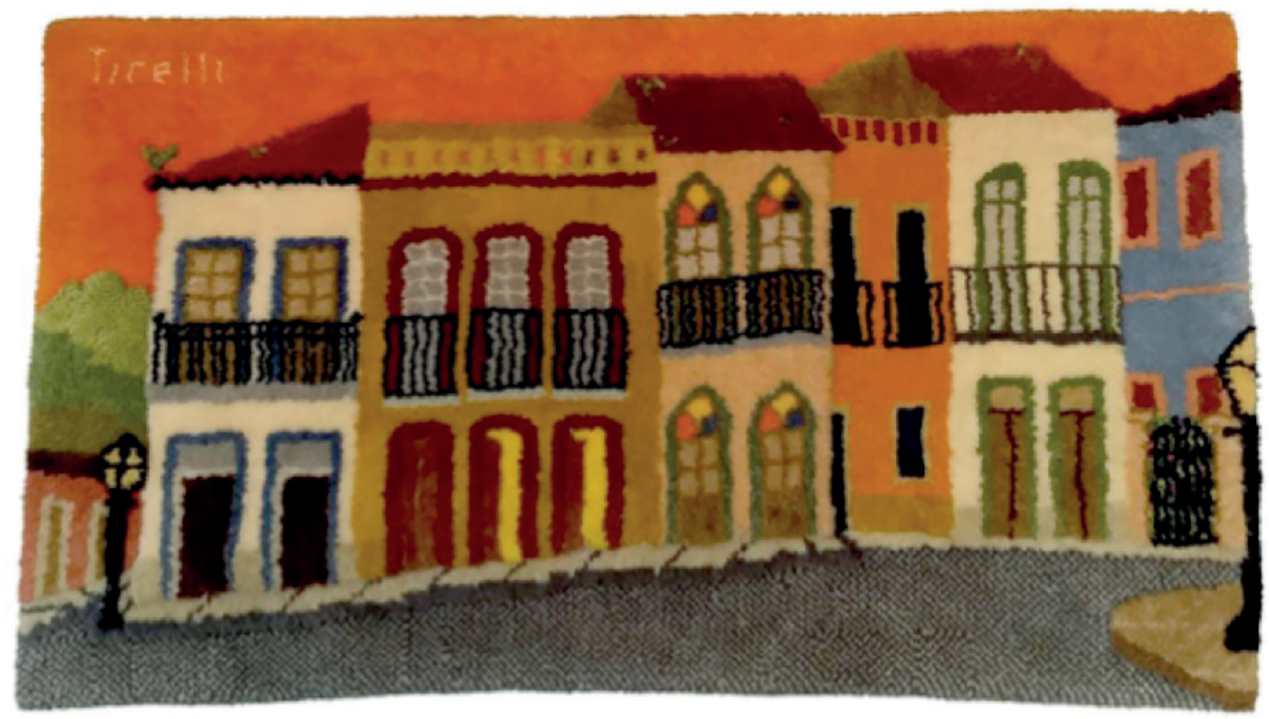

Figura 8 - Almir Tirelli. Rua Fernando Machado com a Praça XV de Novembro.

Dimensões: 1,30 x 0,75 m. Sem notas.

Fonte: Disponível em: http://www.bomdiafloripa.com.br/Edi\%20050.pdf Acesso em: 23 mar.2021. 

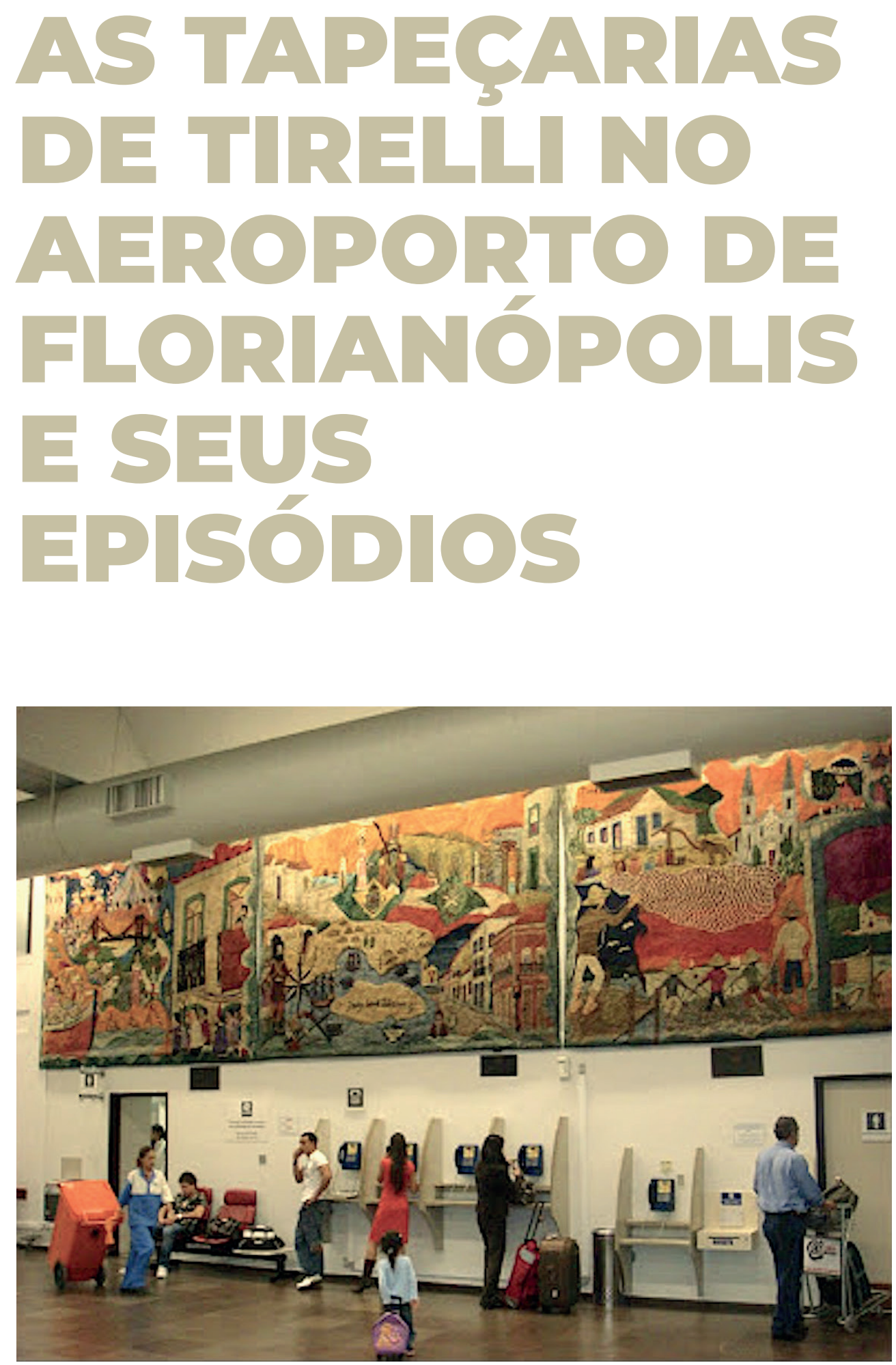

Figura 9 - Aeroporto de Florianópolis

Fonte: Disponível em: http://allehgorie.blogspot.com/2010/03/. Acesso em: 10 mar. 2021. 


\section{EPISÓDIO NUMERO 1 - \\ ANO DE 2009, TAPEÇARIAS \\ DESAPARECEM}

"Tapeçaria de Tirelli desapareceu do saguão do aeroporto, no ano de 2009". Com essa chamada, a matéria do Jornal Bom Dia, de agosto de 2018 (TAPEÇARIA..., 2018), noticia que o conjunto de três painéis vale mais de $R$ \$ 200 mil. É patrimônio de Florianópolis e considerada a maior tapeçaria já feita à mão (Figura 9). Faltam-me dados para confirmar essa afirmação em termos mundiais, mas, em Santa Catarina, não resta dúvida de que procede.

A tapeçaria de Tirelli foi colocada, na década de 70, no saguão do Aeroporto Hercílio Luz (Floripa Airport), criada exclusivamente para recepcionar os viajantes que chegavam ao aeroporto da cidade, inaugurado em 1976. As peças apresentam elementos do cotidiano ilhéu.

Segue a matéria dizendo que a tapeçaria multicolorida do artista Almir Tirelli, dividida em três painéis, que durante anos ficou exposta na parede do saguão do Aeroporto Internacional Hercílio Luz (hoje Floripa Airport), desapareceu. Os painéis abordam flagrantes da vida catarinense e aspectos da história de Florianópolis - o palácio Cruz e Sousa, os rituais religiosos, os pescadores, a ponte Hercílio Luz, as brincadeiras. Almir Tirelli conseguiu tecer, com delicadeza e precisão, registros históricos, lendas e o folclore da Ilha de Santa Catarina, de forma tão equilibrada, que o painel pode ser comparado a um grande livro aberto.

A obra de arte que estava no aeroporto é uma verdadeira relíquia do artista maranhense. É considerada uma das maiores tapeçarias já confeccionadas artesanalmente, com seus três painéis feitos à mão. Verdadeiro patrimônio cultural de Florianópolis, os painéis representam, também, uma época em que o mecenato era comportamento usual entre os grandes empresários catarinenses, que estimulavam a produção cultural com o financiamento de artistas e de suas obras. Sobre esse último comentário, não posso afirmar que o mecenato era comportamento usual entre os grandes empresários catarinenses, pois desconheço.

Os painéis de Almir Tirelli foram doados à cidade para ficarem expostos em sua porta de entrada mais sofisticada, o hall do aeroporto, na área de desembarque, para que os visitantes pudessem apreciar a arte, os costumes, a arquitetura da época colonial de Florianópolis. 


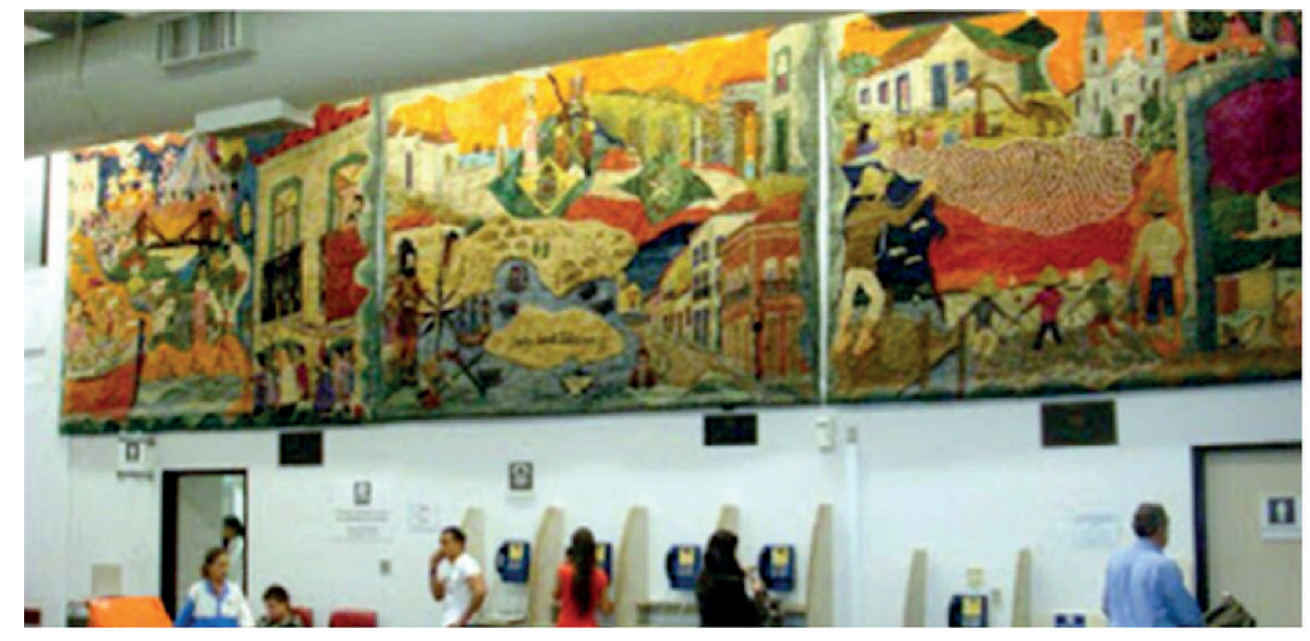

Figura 10 - Aeroporto de Florianópolis

Fonte: Disponível em: http://desastresaereosnews.blogspot.com/2010/03/tapecaria-dealmir-tirelli-e-recolocada.html. Acesso em: 15 mar. 2021. 


\section{OS MECENAS DAS

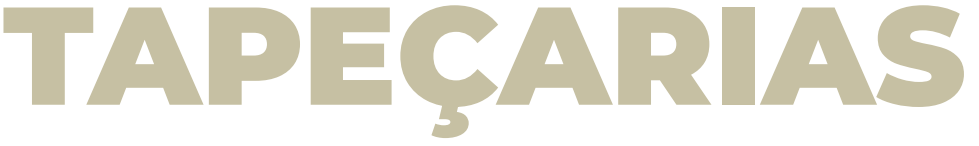

Abaixo de cada tapeçaria, uma placa de bronze indicava o mecenas, como forma de reconhecimento à doação. Um dos painéis foi financiado pelo empresário Diomício Freitas, dono de minas de carvão no Sul do Estado. Outro mecenas foi Omar Fontana, da TransBrasil, filho do fundador da Sadia, Atílio Fontana. O terceiro mecenas foi a Emedaux, que, até o início dos anos 1980, era uma das maiores construtoras de Florianópolis, comandada por Luiz Elias Daux.

Em julho de 2009, a tapeçaria desapareceu e foi recolocada 10 meses depois. Ao longo desse tempo, as peças ficaram sob os cuidados do mestre tapeceiro iraniano Soheil Manshadi, que usou todos os recursos - do olhar apurado ao microscópico - para decifrar as cores de Tirelli. Os painéis estavam colocados no saguão há mais de 30 anos, estavam úmidos, sujos e desbotados.

A restauração da tapeçaria foi demorada. A parte de trás da obra teve de ser lavada a seco e com injeção de gás carbônico, nó por nó. Mas o maior desafio não foi esse. Com a tapeçaria limpa, o restaurador teve de preparar a tinta na mesma tonalidade da obra original. No caso dos painéis do aeroporto, Tirelli usou muitas tonalidades do azul para retratar o mar. A lã também teve de ser recardada (o técnico vai à raiz da lã, para desenredar), segundo relato à época do Allehgorie, site dos alunos do curso superior de Tecnologia em Conservação e Restauro de Bens Culturais do Centro Universitário Unieuro (TAPEÇARIA..., 2010a).

Usando fotografias como guias, o restaurador, em determinadas áreas da peça, avaliou cada nó com microscópio para ter a informação precisa da tonalidade para repigmentação. No caso do painel de Tirelli, foram quase seis meses de trabalho. Em 2010, em "Notícias sobre aviação" (TAPEÇARIA..., 2010b), consta a matéria que diz que a tapeçaria de Almir Tirelli é recolocada na parede do Aeroporto Hercílio Luz (SC). O grande painel criado pelo artista plástico Almir Tirelli estava de volta ao saguão do Aeroporto Hercílio Luz, em Florianópolis. A obra foi recolocada depois de 10 
meses de completa restauração.

Dividido em três peças, o painel com 36 metros quadrados destaca-se na parede cinza pela profusão de cores e de imagens. Um olhar apenas não basta para compreender a grandiosidade do trabalho do artista em que as cenas parecem brincar de esconde-esconde com quem contempla a obra.

O primeiro passo em uma restauração dessa natureza é munir-se de toda a informação possível para chegar mais próximo da imagem original. As fotografias servem de grandes guias do restaurador. Só para ter-se uma ideia das minúcias do trabalho, em determinadas áreas da peça, ele avalia cada nó com microscópio para ter a informação precisa da tonalidade. Começa então a fase de repigmentação. No caso do painel de Tirelli, foram quase seis meses de trabalho do tapeceiro. A Infraero investiu $R \$ 13$ mil reais na restauração da obra, no ano de 2010.

\section{EPISÓDIO NUMERO 2 - AS OBRAS DA CONSTRUÇÃO DO FLORIPA AIRPORT}

Na página do novo aeroporto de Florianópolis (FLORIPA AIRPORT, 2021), consta a seguinte informação: "Quando assumiu a administração do Aeroporto Internacional de Florianópolis, a Floripa Airport realizou uma série de melhorias no terminal antigo, operado entre janeiro de 2018 até 30 de setembro de 2019". Assim, as obras do novo aeroporto ocorreram nesse período de tempo. Em página da Prefeitura, consta que o início das obras ocorreu em 15 de janeiro de 2018 (AEROPORTO..., 2021). Menciona a capacidade para 8 milhões de passageiros por ano e complementa que "Ao estilo preciso de um relógio suíço, o futuro está logo ali, em $1^{\circ}$ outubro de 2019, quando estes atributos e outros de última geração irão se materializar no novo Aeroporto Internacional de Florianópolis - Hercílio Luz". O material diz ainda que o Aeroporto Internacional de Florianópolis -- Hercílio Luz -- é o 14. ${ }^{\circ}$ mais movimentado do País e está na lista dos que mais recebem voos charter na temporada de verão. A cultura e os belíssimos pontos turísticos da capital catarinense inspiraram o artista plástico maranhense, Almir Tirelli, que, para o Aeroporto de Florianópolis, as maiores tapeçarias já feitas artesanalmente no Brasil. As três peças que compõem a obra estão expostas no saguão do aeroporto e estampam o 
ilhéu e seu artesanato elaborado pelos imigrantes açorianos, em cenas em que a confecção da rede de pesca, as rendas e outras atividades manuais ganharam cores vivas e movimento.

Estão expostas também três placas comemorativas referentes à

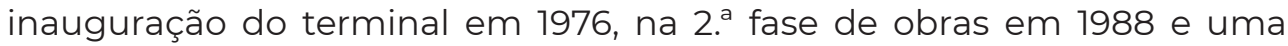
homenagem ao poeta catarinense, Cruz e Sousa. No desembarque internacional, encontra-se um belíssimo vitrô com paisagens que refletem as cidades de Blumenau e a Praia de Balneário Camboriú, e no embarque doméstico, um painel do artista Djalma Urban.

\section{EPISÓDIO NUMERO 3 - FLORIPA GANHA NOVO AEROPORTO}

Floripa ganha novo aeroporto, mas tapeçarias de Tirelli continuam desaparecidas - hora de devolver à cidade as tapeçarias de Tirelli. Com a construção do novo aeroporto, as tapeçarias desapareceram. Diz a matéria que a empresa Floripa Airport, subsidiária do grupo Zurich Airport, que mostrou extrema competência na construção do novo aeroporto internacional da Capital, poderia ajudar a restituir ao patrimônio cultural de Florianópolis as três tapeçarias de Tirelli que sumiram do saguão do velho aeroporto na troca de gestores. O conjunto de painéis com três peças é valioso e considerado a maior tapeçaria já feita à mão. Mas desde que saiu a Infraero para a entrada da Floripa Airport, as tapeçarias foram retiradas e ninguém sabe onde esse patrimônio da cidade foi parar (FLORIPA..., 2019).

Nesse período (2019), após a inauguração e sem as tapeçarias, começaram os questionamentos. Em seu facebook, Paulo Arenhart publica, em 12 de novembro de 2019 (RESENDE apud ARENHART, 2019), uma resposta da Infraero ao seu questionamento sobre as obras do Tirelli, retiradas do antigo terminal do Aeroporto Hercílio Luz. Diz a mensagem, em texto de Angélica Aguiar Nunes Resende, da gerência de Patrimônio:

Informamos que as obras foram transferidas para o Aeroporto de Curitiba, está sob guarda e responsabilidade de empregado da Infraero. Quanto ao direcionamento das obras de arte, estamos em contato com o Instituto Brasileiro de Museus - Ibram, para nos apoiar quanto ao assunto [...] Acho que a FCC - Fundação Catarinense de Cultura ou o Masc - Museu de Arte de Santa Catarina, deveriam ir atrás para recuperar este acervo do Estado de SC. (RESENDE apud ARENHART, 2019). 
Dessa resposta, Paulo deduziu que cabia ao MASC e à FCC solicitar a guarda da obra ou a doação, para que ficasse no Estado de Santa Catarina, pois os atuais gestores do aeroporto não têm mais nada a ver com as obras. Lélia Nunes (apud ARENHARD, 2019) comentou que, do período que presidiu a FCC, (1997/2004), não tinha esse registro da obra na Coordenadoria de Patrimônio. Um Termo de Doação ou de Comodato dessa natureza, se existiu, devia estar na PG do município, acrescentou. Por fim, Lélia Nunes escreve:

Últimas notícias que recebi, via grupo Floripa Sustentável. Zena Becker está empenhadíssima na recuperação das tapeçarias. Acredito que seja da FCC: 'Hoje à tarde o Superintendente da Infraero me ligou. Aguarda correspondência da FCC/MASC para pronunciamento da Infraero. A correspondência também deverá ser enviada à Angélica. Existe o interesse da doação e não comodato. Vamos preparar a correspondência e enviar. (NUNES apud ARENHART, 2019).

Com esse episódio relatado no Facebook, ao que parece, iniciou-se um movimento para trazer as obras para Santa Catarina ou mesmo para divulgar o fato. Alguns nomes destacam-se, como Paulo Arenhardt, Zena Becker, do Movimento FloripAmanhã, Jurandir Pires Camargo, do Jornal Bom Dia Floripa, Lélia Nunes, Rodolfo Pinto da Luz, senador Esperidião Amin, Ana Lúcia Coutinho. Em 8 de julho de 2020, uma postagem no Facebook de Lélia Nunes:

Viva, afinal alguém prestou atenção ao nosso questionamento: Onde está e quem se responsabiliza pelo retorno das belas tapeçarias do Tirelli que contam a história de Florianópolis? Localizada em Curitiba no final de 2019. Está no aeroporto de Curitiba sob a guarda da Infraero. Desde 16 de junho um documento da Infraero informa que aguarda a posição oficial do órgão competente. Também nós, do Floripa Sustentável aguardamos e queremos que venha para Florianópolis. Amém! (NUNES, 2020).

Em foto de reportagem estampada nesse post do Facebook de Lélia Nunes, aparece uma nota de Moacir Pereira, em que diz que a Infraero, consultada, libera as tapeçarias, se houver manifestação oficial das autoridades catarinenses. 


\section{EPISODIO NÚMERO 4 - \\ FUNDAÇÃO CATARINENSE DE CULTURA ENTRA EM CENA}

Ana Lúcia Coutinho assumiu a empreitada pela FCC. Tapeçaria de Almir Tirelli volta a Santa Catarina após assinatura de termo de doação entre Fundação Catarinense de Cultura e Infraero, diz a chamada da reportagem de 23 de outubro de 2020 (TAPEÇARIA ..., 2020). Diz a matéria que a tapeçaria criada por Almir Tirelli para o antigo saguão do Aeroporto Hercílio Luz, em Florianópolis, está voltando para Santa Catarina. O retorno deve-se a um termo de doação assinado entre a Fundação Catarinense de Cultura (FCC) e a Empresa Brasileira de Infraestrutura Aeroportuária (Infraero) nesta sexta-feira (23), em Curitiba (PR), onde a obra estava salvaguardada. $\bigcirc$ transporte das obras foi feito em parceria com a Polícia Militar de Santa Catarina (PMSC), que cedeu um caminhão para o traslado.

Os três painéis que compõem a obra voltarão à Capital e ficarão sob guarda da Fundação Catarinense de Cultura (FCC). A assinatura da doação foi acompanhada pelo técnico Marcelo do Amaral, do Ateliê de Conservação e Restauração de Bens Culturais Móveis (Atecor) da FCC, que fez um diagnóstico do estado de conservação das peças. As tapeçarias passaram por um processo de higienização.

Especialistas em conservação e restauração realizaram a última etapa de higienização da tapeçaria de Almir Tirelli. A tapeçaria passou por um processo de fumigação com produtos especiais. Depois, recebeu higienização mecânica por aspersão. Após essas etapas, as tapeçarias estão prontas para serem exibidas ao público.

A respeito de todo esse episódio, restam especulações não esclarecidas. Entrei em contato com Cris Vieira, coordenadora de comunicação do Floripa Airport, em 18 de março de 2021, para que me respondesse ao seguinte questionamento: "Procede a informação apenas ventilada que a nova administração abriu mão de acolher as tapeçarias, alegando não ter espaço adequado e/ou que as tapeçarias não se adequavam ao conceito do novo aeroporto?" Ela gentilmente respondeu-me por e-mail informando o posicionamento do Floripa Airport com relação às tapeçarias e o motivo pelo qual a concessionária solicitou a retirada das tapeçarias, ainda na época do antigo terminal. 
A tapeçaria do artista Tirelli é um patrimônio da Infraero. Considerando que o aeroporto passaria por uma série de reformas e entendendo que o conhecimento sobre a origem e o valor material e imaterial da peça é da Infraero, a Floripa Airport pediu para que o órgão retirasse a obra de arte do aeroporto para assegurar sua integridade. (VIEIRA, 2021a).

Agradeci a resposta e acentuei que esse fato já era de meu conhecimento e que minha questão era outra, ou seja, não era a retirada, mas se havia ocorrido ou não alguma intenção por arte da Infraero e da administração do Floripa Airport em abrigar novamente as tapeçarias de Almir Tirelli. Em 22 de março, recebo nova resposta:

A Tapeçaria Tirelli nunca fez parte da relação de bens concessionados à Floripa Airport. Levando em conta a importância da obra e o fato de não ser um patrimônio da concessionária, entendemos que o mais correto era o proprietário, no caso a Infraero, providenciar o destino adequado. (VIEIRA, 2021b).

\section{EPISÓDIO NUMERO 5 - UM CONVITE}

Recebo um convite para fazer um texto de apresentação da exposição que abrirá ao público, exibindo as tapeçarias que retornaram para Santa Catarina, por parte de Lena Peixer, diretora do Museu Histórico de Santa Catarina (MHSC).

A pandemia atrasou uma vez mais a exposição, que abriria em fevereiro ou março de 2021 (confesso que não recordo mais).

Assim, vamos às obras, destacadas no corpo do texto, deixando claro que as fichas técnicas das obras, que constam anexas, foram enviadas a mim, com auxílio de Rodrigo Rosa, por Marcelo do Amaral (ambos da FCC), que me atenderam prontamente. Ana Lúcia Coutinho também prontamente respondeu-me sobre os fatos que Ihe diziam respeito e sobre os quais tinha conhecimento. 


\section{OS PAINÉIS: O TRÍPTICO DE ALMIR TIRELLI}

Segue uma única foto existente desses painéis em redes sociais, fato que, por si só, ilustra uma vez mais esse ocaso ao qual me refiro (Figuras 11-12).

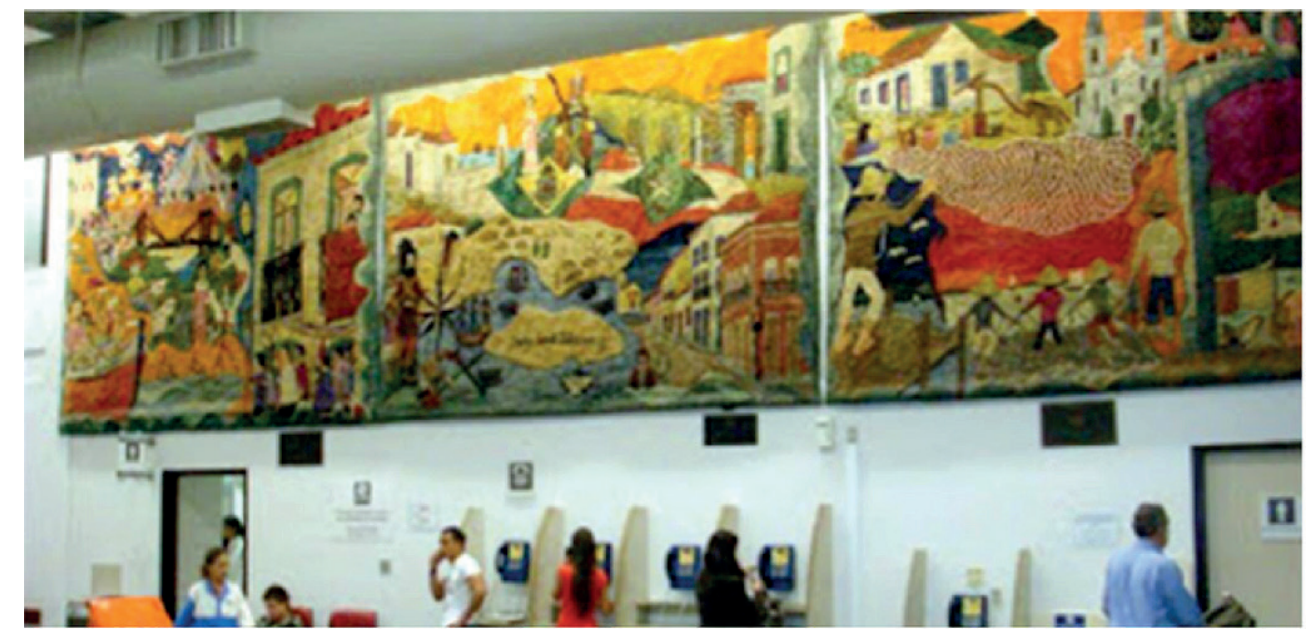

Figura 11 - Aeroporto de Florianópolis

Fonte: Disponível em: http://desastresaereosnews.blogspot.com/2010/03/tapecaria-dealmir-tirelli-e-recolocada.html. Acesso em: 15 mar. 2021. 


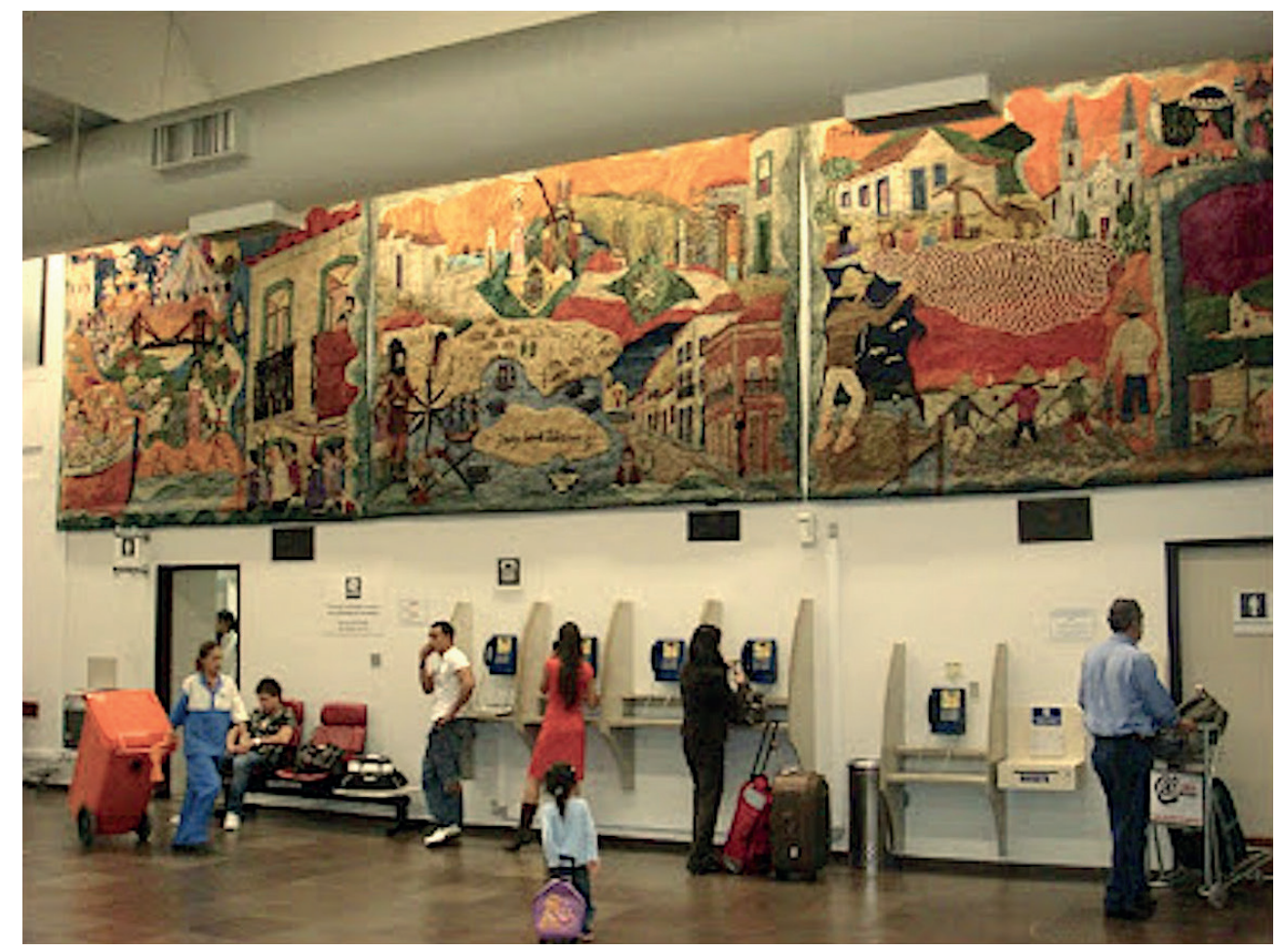

Figura 12 - Aeroporto de Florianópolis

Fonte: Disponível em: http://desastresaereosnews.blogspot.com/2010/03/tapecaria-dealmir-tirelli-e-recolocada.html. Acesso em: 15 mar. 2021.

Os painéis constituem um tríptico que, geralmente, é um conjunto de três obras unidas por uma moldura tríplice (dando o aspecto de serem uma obra), ou somente três obras juntas formando uma única imagem (Figuras 13 a 17).

Apesar da conexão com o formato artístico, o termo pode, às vezes, ser usado mais comumente como conotação para qualquer composição de três partes, particularmente se for uma integração para uma única unidade. 


\section{PAINEL NÚMERO 1 DO TRÍPTICO}

\section{(da esquerda para a direita, considerando a foto do saguão do aeroporto)}

Título (ou descrição da imagem): arquitetura, celebrações e tradições relacionadas à cultura da Ilha de Santa Catarina: ponte Hercílio Luz, carnaval de rua, carro alegórico da sociedade carnavalesca Tenentes do Diabo, procissão de Nossa Senhora dos Navegantes na embarcação "Stela Maris", procissão Nosso Senhor dos Passos, Boi de Mamão e Pau de Fita. Nesse painel, Almir Tirelli realça algo a que ele se dedicava bastante folclore e costumes da ilha.

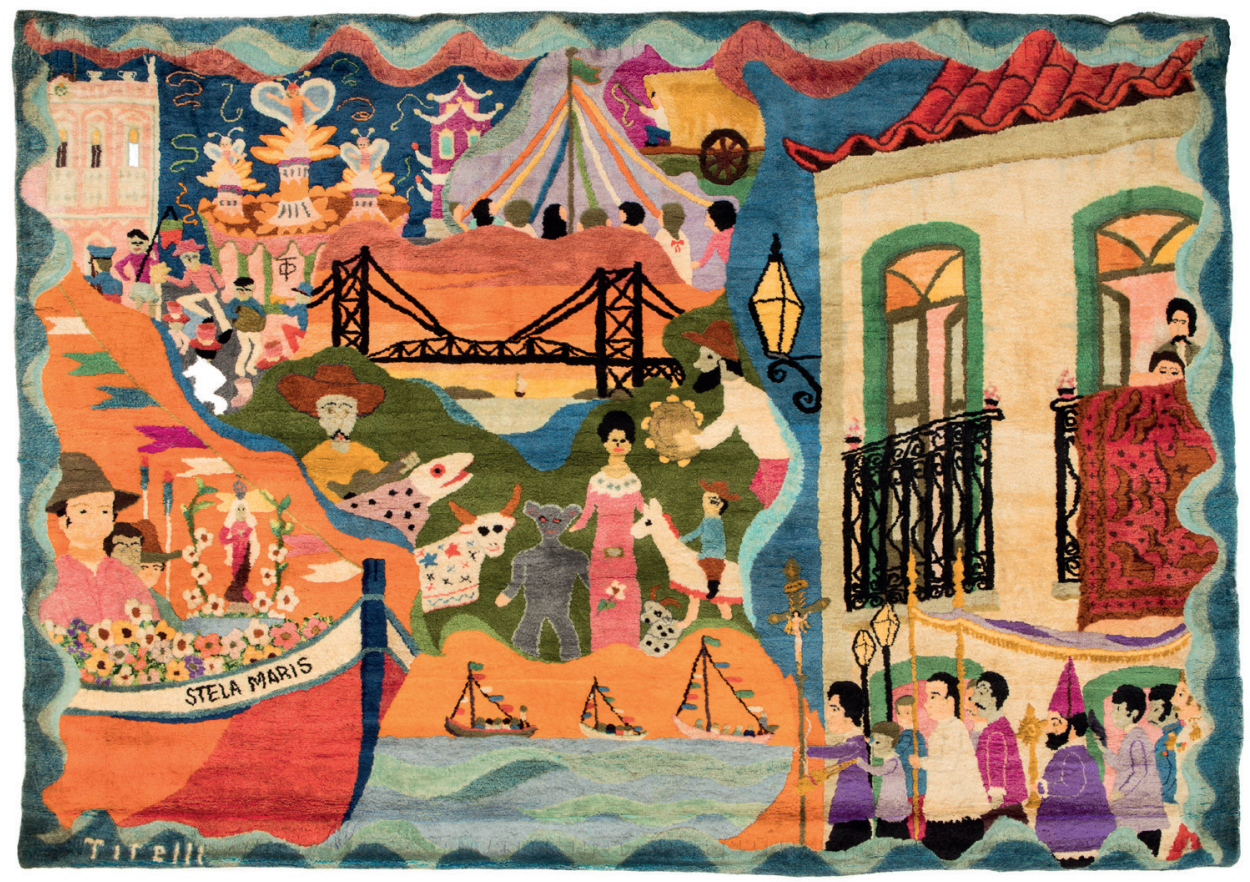

Figura 13 - Almir Tirelli Dias. 1974. Tapeçaria em lã. Dimensões: 2,95 m x 4, 05 m. Proprietário: Fundação Catarinense de Cultura. Número de Tombo: 1-0064.7.62 (Patrimônio INFRAERO. Termo de doação em andamento). Fonte: Fotografia de Carlos Pontalti. 


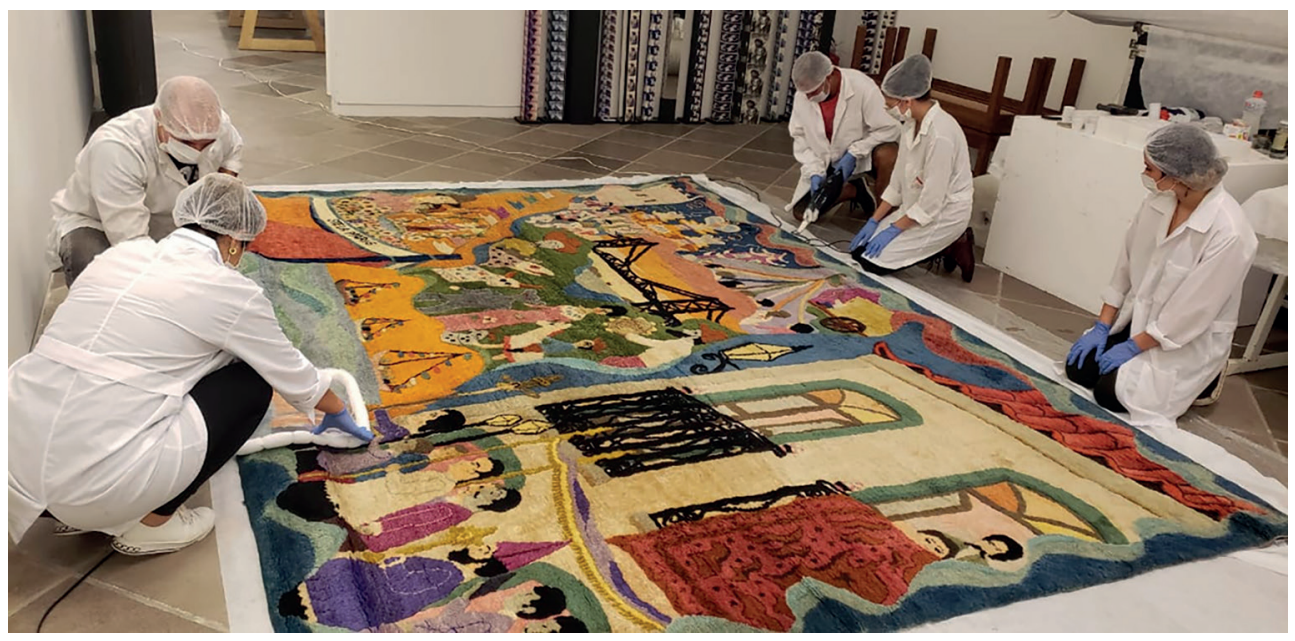

Figura 14 - Tapeçaria sendo tratada pelos técnicos da FCC. Outubro de 2020. Foto: Carolina Rios (divulgação/FCC)

Fonte: Disponível em: http://floripamanha.org/2020/12/tapecaria-de-tirelli-passa-porultima-etapa-de-higienizacao-em-florianopolis/. Acesso em: 14 mar. 2021. 


\section{PAINEL NÚMERO 2 DO TRÍPTICO}

(da esquerda para a direita, considerando a foto do saguão do aeroporto)

Título (ou descrição da imagem): elementos históricose arquitetônicos da Ilha de Santa Catarina: Fortaleza de São José da Ponta Grossa, representação do mapa da Injulce Sancte Katerinia - 1549, com embarcações dos primeiros habitantes e incursões de navegantes colonizadores, Francisco Dias Velho; Bandeiras do Brasil Imperial e de Santa Catarina, Imperatriz Leopoldina, D. Pedro, casarios luso-brasileiros, aqueduto de São Miguel e Casa do Açores. Nesse painel, Almir Tirelli realça algo a que ele se dedicava bastante, qual seja, a arquitetura do Brasil Colonial e Imperial.

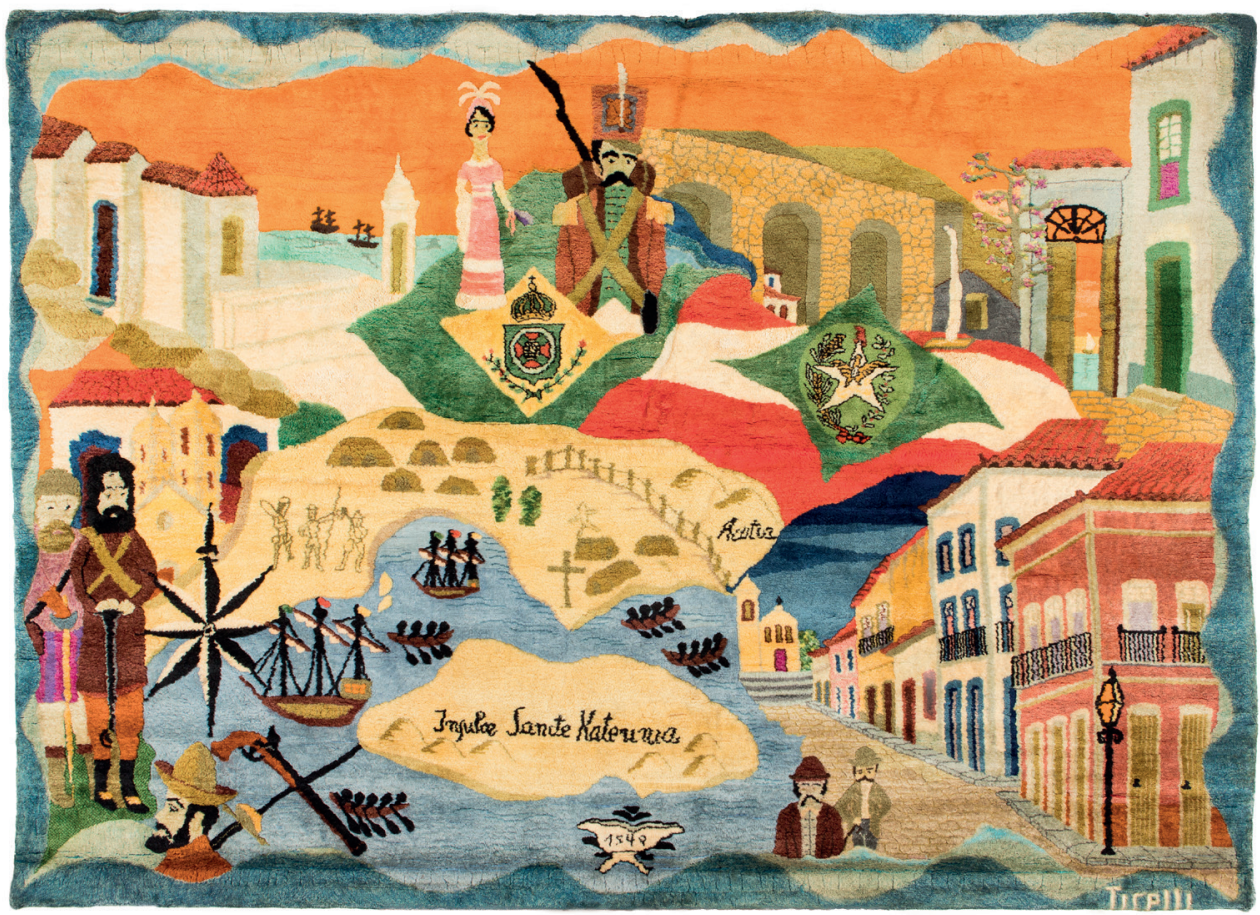

Figura 15A - Almir Tirelli Dias. 1974. Tapeçaria em lã. Dimensões: 2,855 m x 3,85 m. Proprietário: Fundação Catarinense de Cultura. Número de Tombo: 1-0064.7.60 (Patrimônio INFRAERO). Termo de doação em andamento.

Fonte: Fotografia de Carlos Pontalti 


\section{A RELAÇÃO DO PAINEL NÚMERO 2 DE TIRELLI COM A HISTÓRIA}

No livro Theodore de Bry - America - The Complete Plates 1590-1602, de Michael Van Groesen e Larry E. Tise, editora Taschen, Plate 6. Cap. IX, 2020, vemos uma imagem do primeiro mapa da ilha de Santa Catarina (Figura 15B). Théodore de Bry, nascido em 1528, na Bélgica, foi um gravurista, ourives e editor famoso por suas representações das primeiras expedições europeias às Américas. Viveu em Londres entre os anos de 1585 e 1588, onde expôs seus trabalhos sobre a exploração do Novo Mundo. Theodore de Bry inspirou-se em alguns dos maiores exploradores da história para registrar suas maravilhas. Sua obra cativou a imaginação europeia com visões de paisagens, costumes e povos recém-descobertos. O livro reúne reproduções de suas melhores gravuras de relatos de viagens de aventureiros. A gravura abaixo refere-se à viagem de Hans Staden ao Brasil e Santa Catarina.

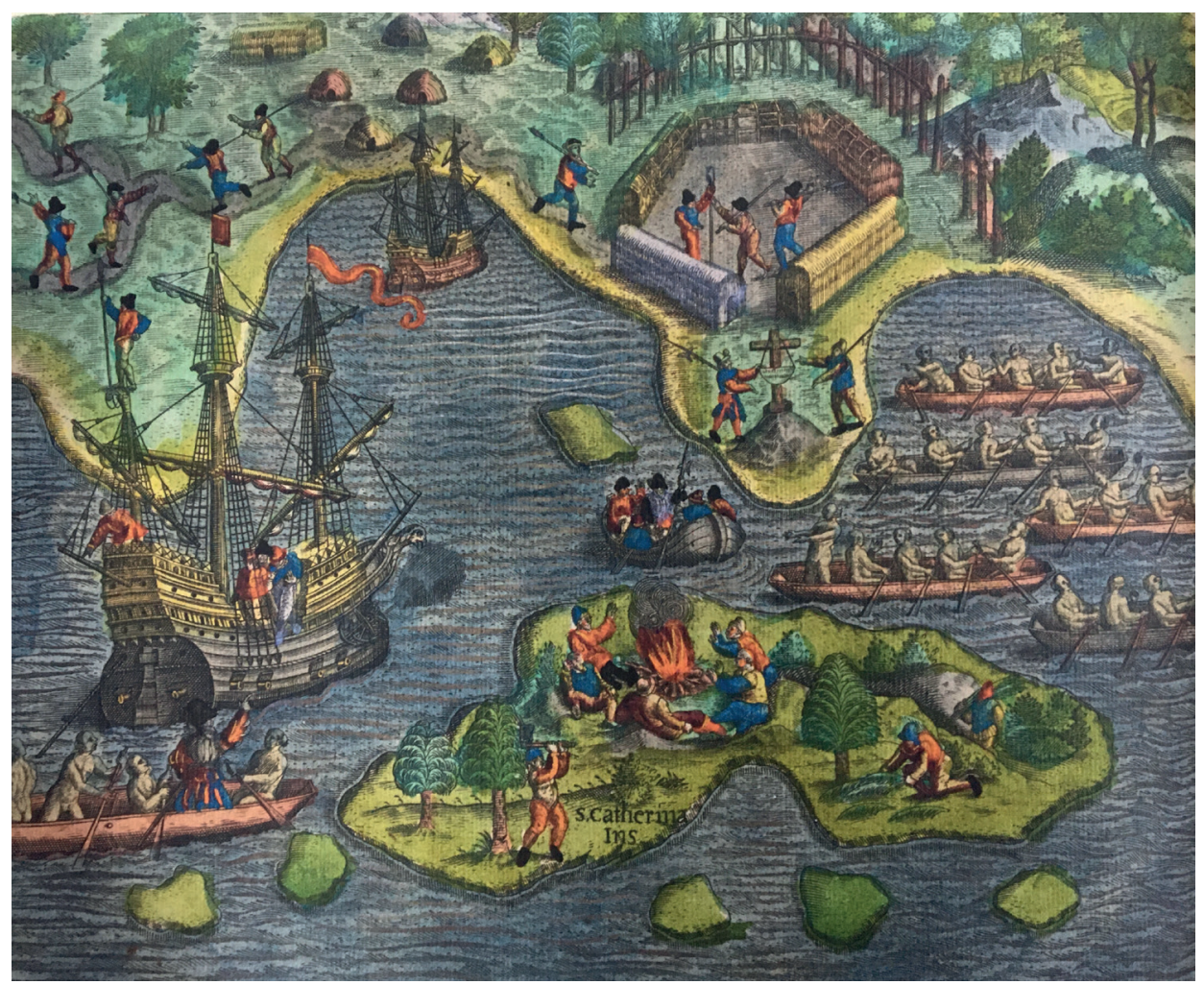

Figura 15B - Theodor de Bry - (1593) Hans Staden chega na Ilha de Santa Catarina. Fonte: GROESEN, Michael Van e TISE, Larry E. Theodore de Bry - America - The Complete Plates 1590-1602, editora Taschen, Plate 6, 2020, p.158. 
Sobre essa reprodução, consta o seguinte texto, abaixo do título: "Como alguns de nós saímos para inspecionar o porto e nos deparamos com um crucifixo em uma pedra".

Ancoramos no dia de Santa Catarina de 1549, armamos-nos e saímos para inspecionar o porto em um barco. Rastejamos até avistar algumas cabanas diante de uma densa floresta e fomos em direção a elas. Eram cabanas velhas e não encontramos ninguém morando nelas. Encontramos uma pequena ilha, quando já era noite, para descansar durante a noite. De manhã nos aventuramos mais fundo na ilha para ver se havia gente ali, porque nos convencemos de que devia haver gente morando na área. Enquanto caminhávamos ao redor, vimos à distância um pedaço de madeira preso entre algumas pedras. Nós nos aproximamos e encontramos uma cruz de madeira sustentada por pedras. Tinha um pequeno pedestal anexado, que tinha uma inscrição ilegível. Ficamos imaginando o que as pessoas decidiram erguer aqui. Não sabíamos se aquele era mesmo o porto onde deveríamos estar. Continuamos, deixando a cruz para trás, mas assumindo o pedestal. Um de nós sentou-se com ele e disse, em espanhol: Se um dos navios de sua majestade encontrar esta aventura, dispare um canhão para aprender mais. Voltamos para a cruz, disparamos um canhão de falconete e retomamos nossa exploração. Nesse ponto, cinco barcos se aproximaram de nós rapidamente. Preparamos nosso canhão. Assim que chegaram perto, porém, vimos que um deles usava roupas e tinha barba. Vimos que ele era cristão e perguntamos onde estávamos. Disse que estávamos no porto de Schimerein, como é chamado na língua dos selvagens, batizado de Santa Catarina por seus descobridores. Ficamos contentes de saber disso, pois era este o porto que procurávamos e ali havíamos chegado no dia de Santa Catarina. Saiba então que DEUS ajuda quem o pede com sinceridade em momentos de necessidade. (STADEN apud GROESEN e TISE, 2020, Plate 6, p.158). 


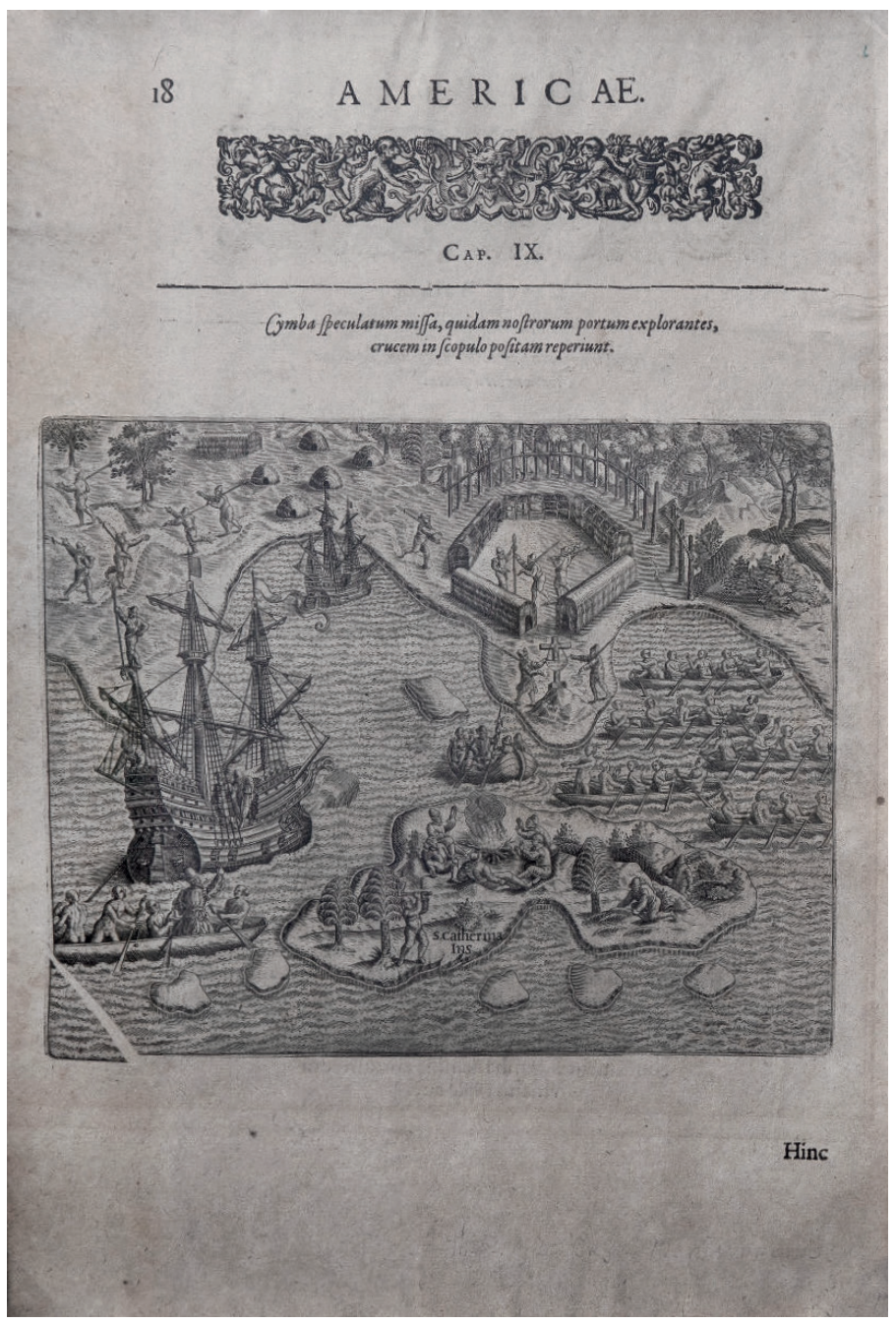

Figura 15C - Ilha de Santa Catarina | 1549. Theodor de Bry [1528-1598], segundo Hans Staden [circa 1525-circa 1576]. Gravura em metal. Gravado por Theodor de Bry.In: Theodor de Bry; Americae Tertia pars memorabilem provinciae Brasiliae Historam Continens. Frankfurt: Mathew Becker, 1592. Dimensões: 34x $23 \mathrm{~cm}$.

Fonte: Coleção Catarina de Ylmar Corrêa Neto.

Hans Staden (c.1525 - c.1576) nasceu na cidade de Homberg, na Alemanha. Foi um viajante e mercenário alemão que ficou conhecido por ter feito duas viagens ao Brasil no século XVI. No ano de 1548, resolveu fazer uma viagem para a América. Seu relato ficou particularmente famoso por ter sido prisioneiro dos tupinambás, durante nove meses, e, após ser libertado, escreveu um relato que ficou famoso na Europa da Idade Moderna.

O livro escrito por Hans Staden foi lançado na Alemanha em 1557 e, atualmente, é conhecido no Brasil como Duas Viagens ao Brasil (STADEN, 
2020). No livro, ele narra as suas aventuras em duas viagens que fez à Terra do Brasil. A primeira viagem foi rápida e sem grandes imprevistos, mas a segunda vinda ao Brasil mudaria a vida do aventureiro. A primeira, passando por Pernambuco e pela Paraíba, e a segunda, quando chegou na ilha de Santa Catarina. Na segunda viagem foi preso pelo governadorgeral e em seguida capturado pelos índios tamoios. O jovem Staden conta o que viu: paisagens virgens, riquezas inexploradas e a prática ritual do canibalismo, do qual por muito pouco não foi vítima. O livro com o seu relato foi publicado em 1557, em Marburgo, Alemanha, ilustrado por xilogravuras anônimas baseadas nas suas descrições.

Ao chegar à ilha de Santa Catarina, em 1549, Staden é feito prisioneiro pelos índios Tamoios. Tendo de conviver vários meses com os indígenas, o alemão passa a observar os costumes dos povos nativos (considerados selvagens e estranhos pelos europeus), a relação de guerra e paz entre as diversas tribos do Brasil e a interação desses povos com os homens brancos vindos da Europa. Em sua narrativa, Staden descreve com detalhes a importância da prática do canibalismo para os indígenas. Realizou uma descrição valiosa dos costumes dos povos que habitavam o sul da América no tempo da colonização, bem como, na segunda parte do livro, descreveu com riqueza de detalhes a topografia, a fauna e a flora da Terra do Brasil. As xilografias que ilustram o livro ajudam a contar essa história tão peculiar e importante para o entendimento da História do Brasil

Depois desse período, os membros da expedição decidiram abandonar a ilha de Santa Catarina em direção a Assunção, no Paraguai, em dois grupos.

O grupo do qual Hans Staden fazia parte alcançaria Assunção com o navio restante. Como o navio era pequeno, resolveram ir para São Vicente fretar um navio maior para levá-los a Assunção. Durante o trajeto para São Vicente, uma tempestade naufragou o navio em que Hans Staden estava. Os sobreviventes avistaram uma pequena vila de cristãos chamada Itanhaém, que ficava nas proximidades de São Vicente.

Certo dia, enquanto caçava, Hans Staden foi surpreendido por vários indígenas que o capturaram eo levaram como prisioneiro. Oaprisionamento de Hans Staden ocorreu a fim de que ele fosse morto e devorado pelos tupinambás. Isso acontecia porque os tupinambás eram antropófagos. Os tupinambás acreditavam que ao devorar a carne humana adquiririam as qualidades de seu adversário.

O cativeiro de Hans Staden durou nove meses e, nesse período, ele 
foi espancado diversas vezes, além de ter sido ameaçado outras tantas. Também presenciou (e participou) de guerras indígenas e deixou um relato com detalhes da cultura e do estilo de vida dos tupinambás.

Depois desses nove meses, foi libertado por franceses que negociaram a libertação de Hans Staden. Hans Staden desembarcou na Europa, na cidade de Honfleur, na França, em 20 de fevereiro de 1555.

O que importa também em todo esse relato é destacar que, segundo Ylmar Corrêa Neto, em depoimento no dia 26 de maio de 2021, Almir Tirelli, ao elaborar o painel número 2 do tríptico, utilizou a gravura como referência, reportando-se ao mapa Injulce Sancte Katerinia - 1549, como consta no painel, em detalhes mais aproximados para estabelecermos a comparação (Figuras 15D e 15E).

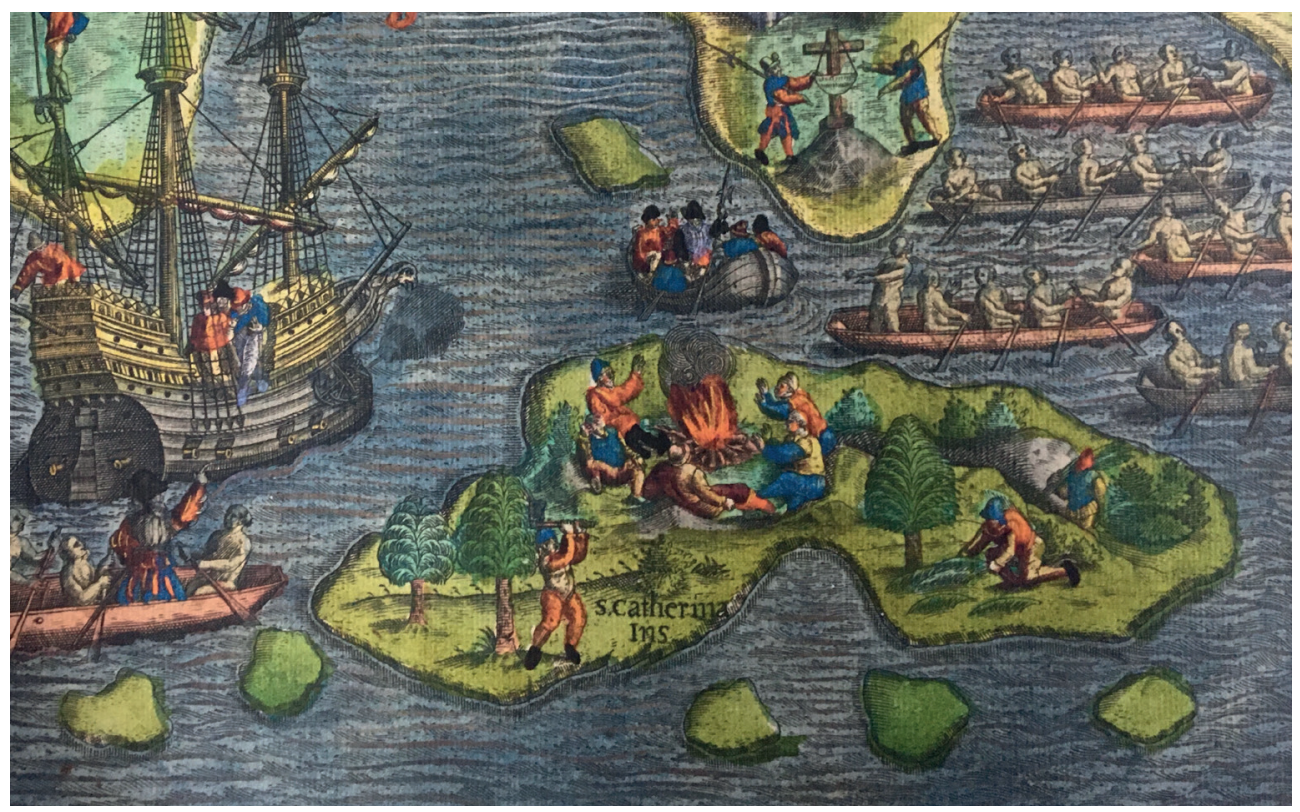

Figura 15D - Detalhe da Figura 15B. Theodor de Bry - (1593) Hans Staden chega na Ilha de Santa Catarina. Fonte: GROESEN, Michael Van e TISE, Larry E. Theodore de Bry America - The Complete Plates 1590-1602, editora Taschen, Plate 6, 2020, p.158. 


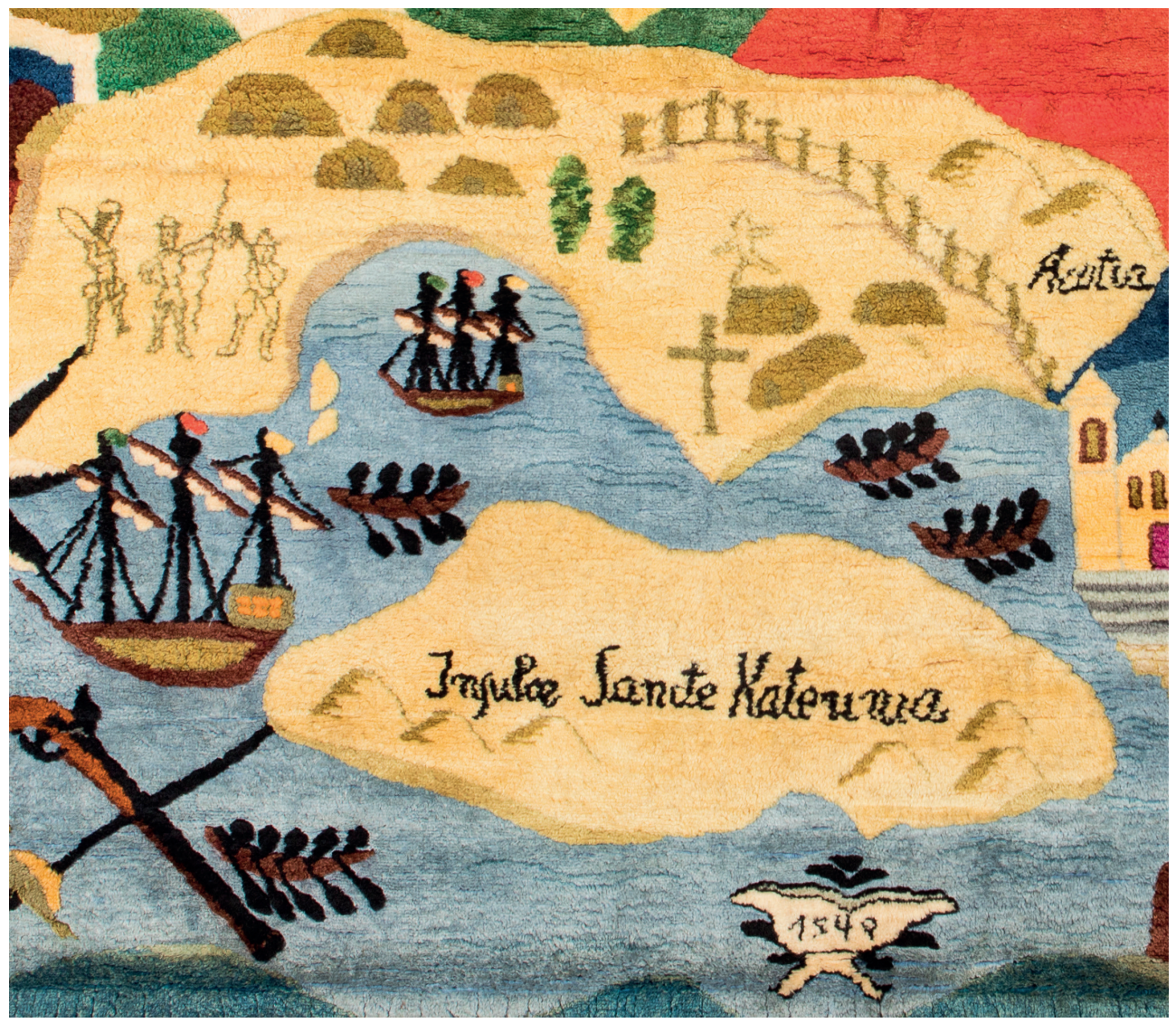

Figura 15E - Detalhe da figura 15A. Almir Tirelli Dias. 1974. Tapeçaria em lã. Dimensões: $2,855 \mathrm{~m} \times 3,85 \mathrm{~m}$.

Proprietário: Fundação Catarinense de Cultura. Número de Tombo: 1-0064.7.60 (Patrimônio INFRAERO). Termo de doação em andamento. Fonte: Fotografia de Carlos Pontalti. 


\section{PAINEL NÚMERO 3 DO TRÍPTICO}

(da esquerda para a direita, considerando a foto do saguão do aeroporto)

Título (ou descrição da imagem): arquitetura, elementos do cotidiano e do saber fazer: casa "Louça de Barro" com potes de cerâmica para pegar água no poço-cacimba, pescador jogando tarrafa do trapiche, arrastão da rede na pesca da tainha, Igreja na praça Sete de Setembro - centro de Palhoça, cortejo Imperial da festa do Divino, Igreja de Nossa Senhora da Imaculada Conceição com a vista da rendeira para a Lagoa da Conceição, com suas rendas de bilro.

O artista nesse painel faz uma junção de variados elementos deslocados no espaço, mas que ilustram cenas e hábitos culturais da grande Florianópolis e que vivenciou. Vemos as igrejas da Palhoça e Igreja da Lagoa da Conceição, locais onde morou. Elementos conhecidos nossos, como pescador, tarrafa, arrastão de rede de pesca, potes de cerâmica para pegar água no poço - cacimba (cacimba, poço raso, também chamado de artesiano, jorrante ou não). Não poderiam faltar as rendas de bilro. Novamente em foco, a arquitetura do Brasil Colonial e Imperial, folclore e costumes brasileiros.

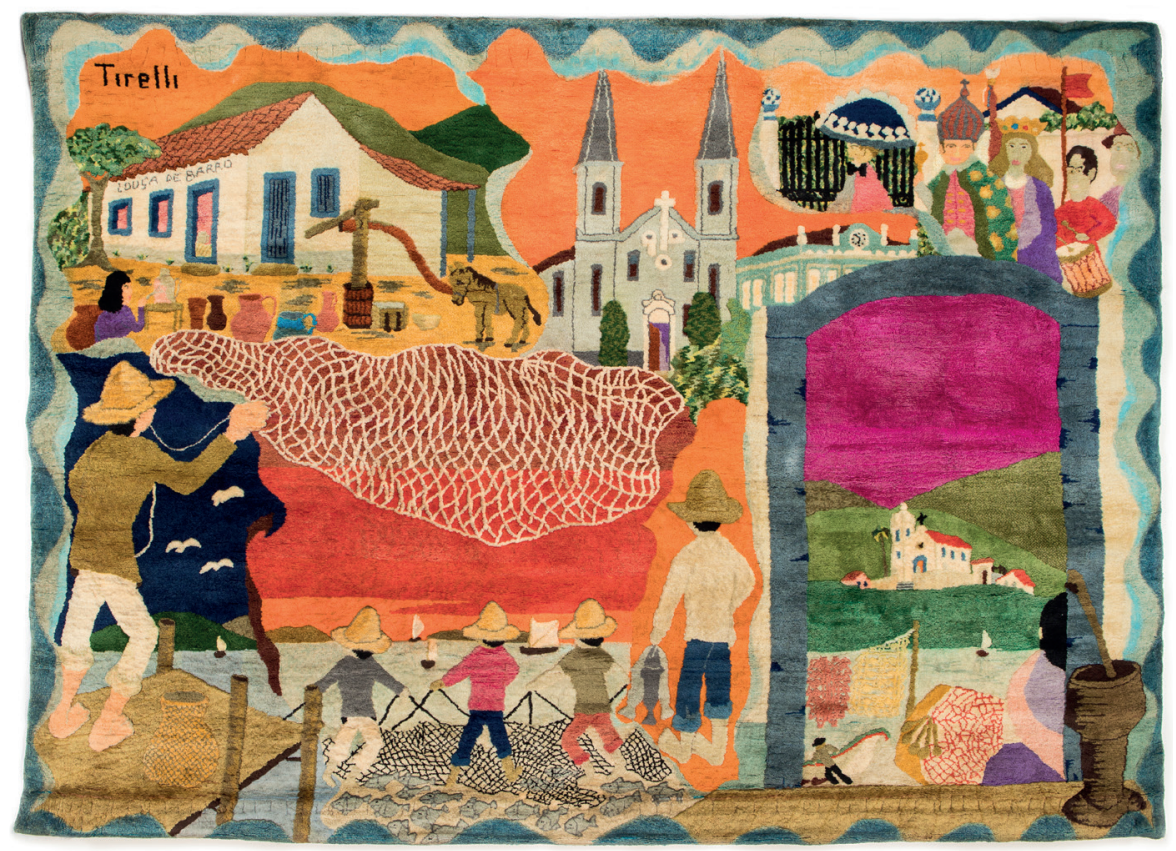

Figura 16 - Almir Tirelli Dias. 1974. Tapeçaria em lã. Dimensões: 2,85 m × 3, 85 m. Proprietário: Fundação Catarinense de Cultura. Número de Tombo: 1-0064.7.61 (Patrimônio INFRAERO). Termo de doação em andamento. Fonte: Fotografia de Carlos Pontalti. 


\section{OUTRAS OBRAS DO ARTISTA E RELAÇÃO COM OUTROS ARTISTAS E OBRAS}

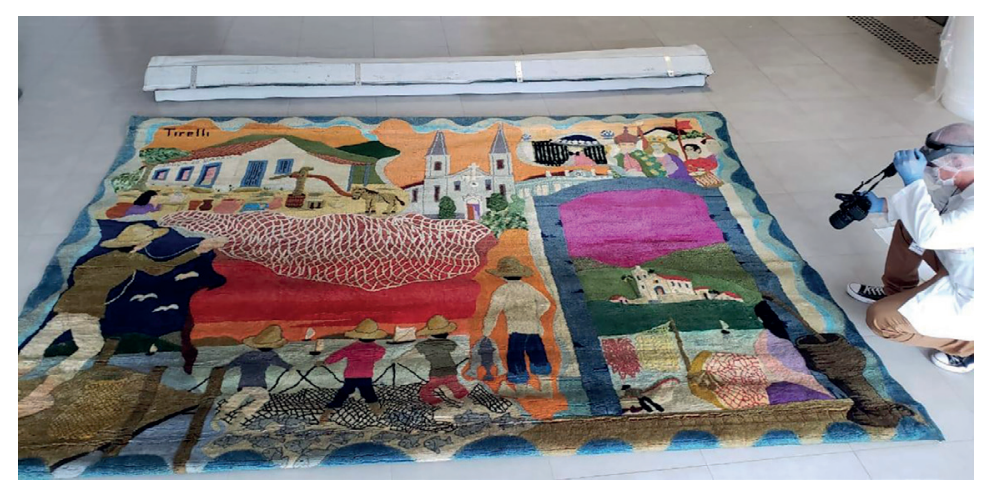

Figura 17 - Almir Tirelli Dias. 1974. Tapeçaria em lã. Dimensões: 2,85 m × 3, 85 m. Proprietário: Fundação Catarinense de Cultura. Número de Tombo: 1-0064.7.61 (Patrimônio INFRAERO). Termo de doação em andamento. Foto: Carolina Rios (divulgação/FCC).

Fonte: Disponível em: https://www.cultura.sc.gov.br/noticias/22798-tapecaria-de-tirellivolta-a-santa-catarina. Acesso em: 14 mar. 2021.

Além dos painéis do tríptico, foram doadas para a Fundação Catarinense de Cultura as obras que seguem (Figuras 18, 19, 20).

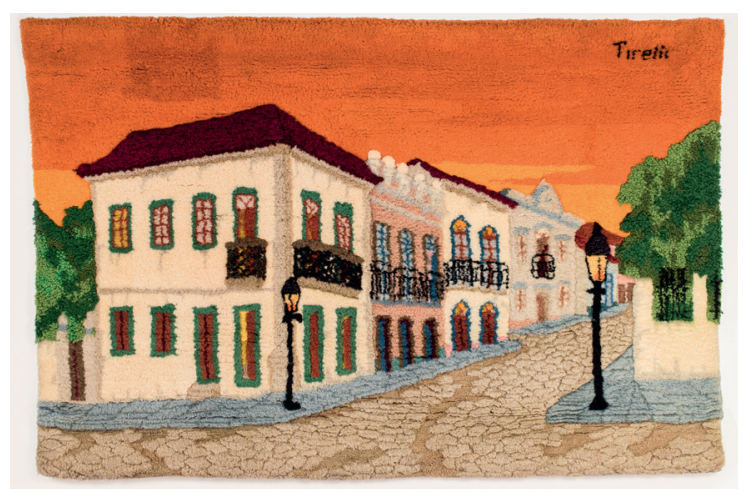

Figura 18 - Almir Tirelli Dias. 1975. Tapeçaria em lã. Dimensões: 1,37 m x 1,95 m. Proprietário: Fundação Catarinense de Cultura. Número de Tombo: 1-0064.0.69 (Patrimônio INFRAERO). Termo de doação em andamento. Fonte: Fotografia de Carlos Pontalti. 
1. Título (ou descrição da imagem): Casarios e ruas transversais da Praça XV de novembro (cercada), Florianópolis

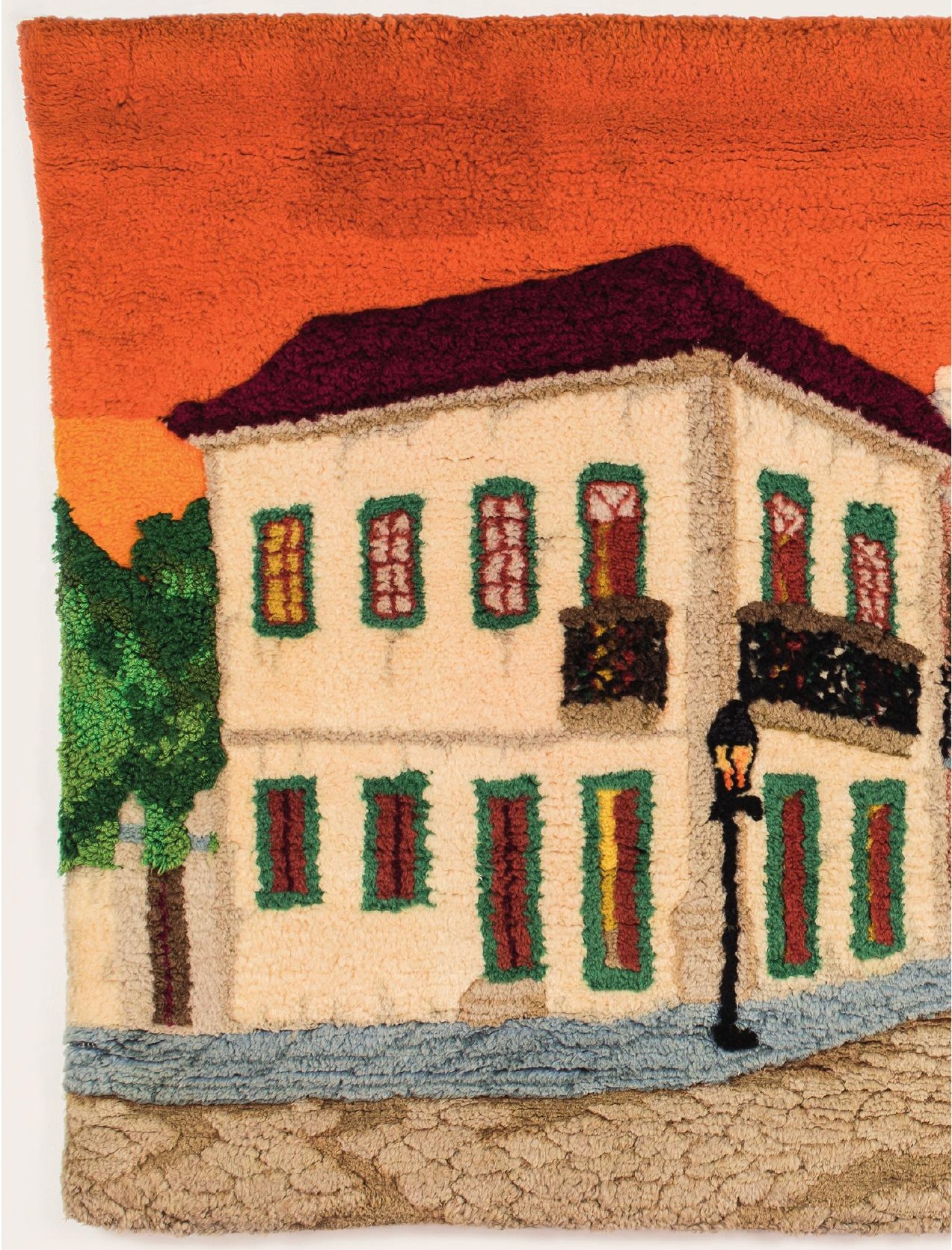




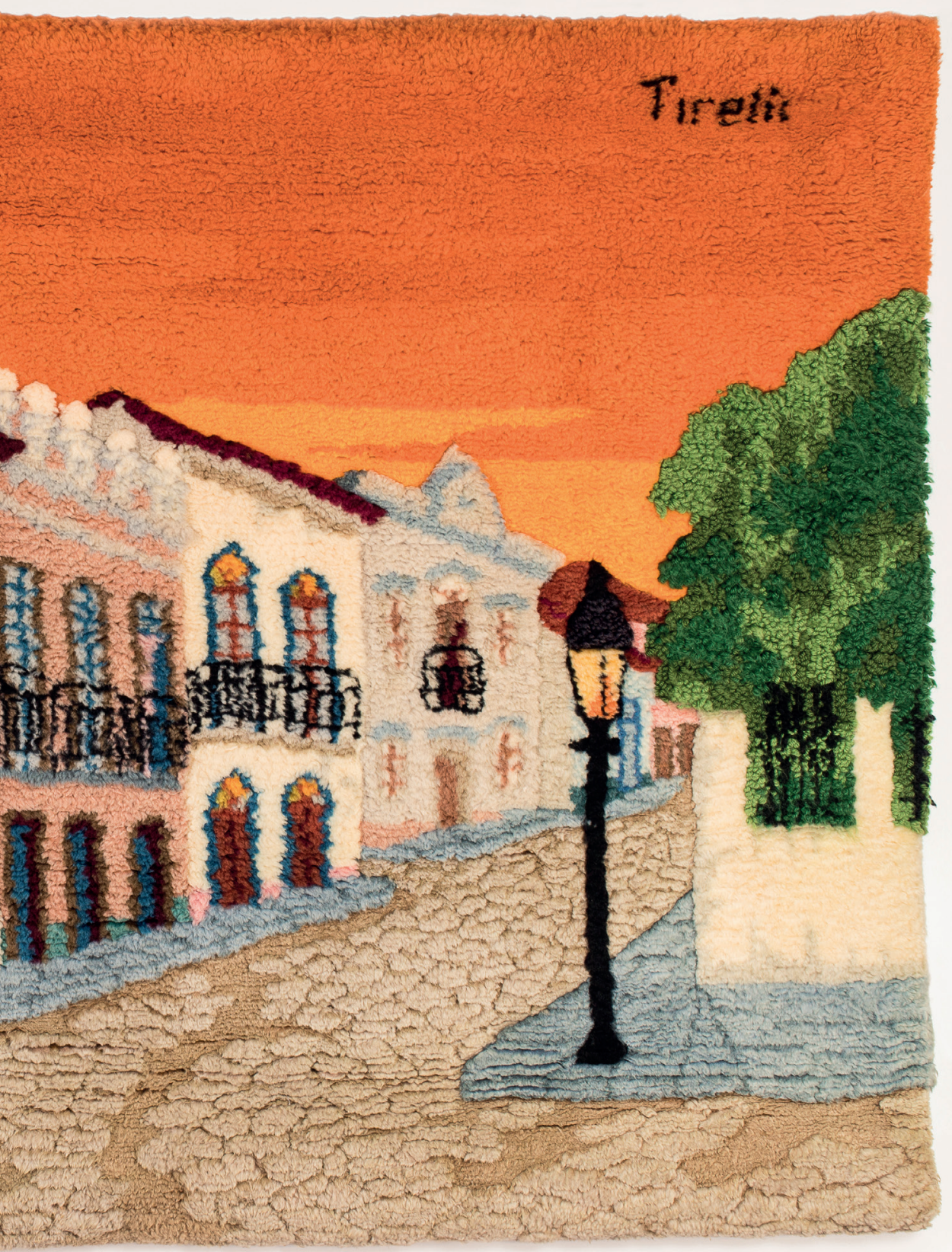

Figura 19 - Almir Tirelli Dias. 1975. Tapeçaria em lã. Dimensões: 1,37 m x 1,95 m. Proprietário: Fundação Catarinense de Cultura. Número de Tombo: 1-0064.0.69 (Patrimônio INFRAERO). Termo de doação em andamento. Fonte: Fotografia de Carlos Poltalti. 
2. Título (ou descrição da imagem): Praça XV- Rio de Janeiro - séc. XVIII

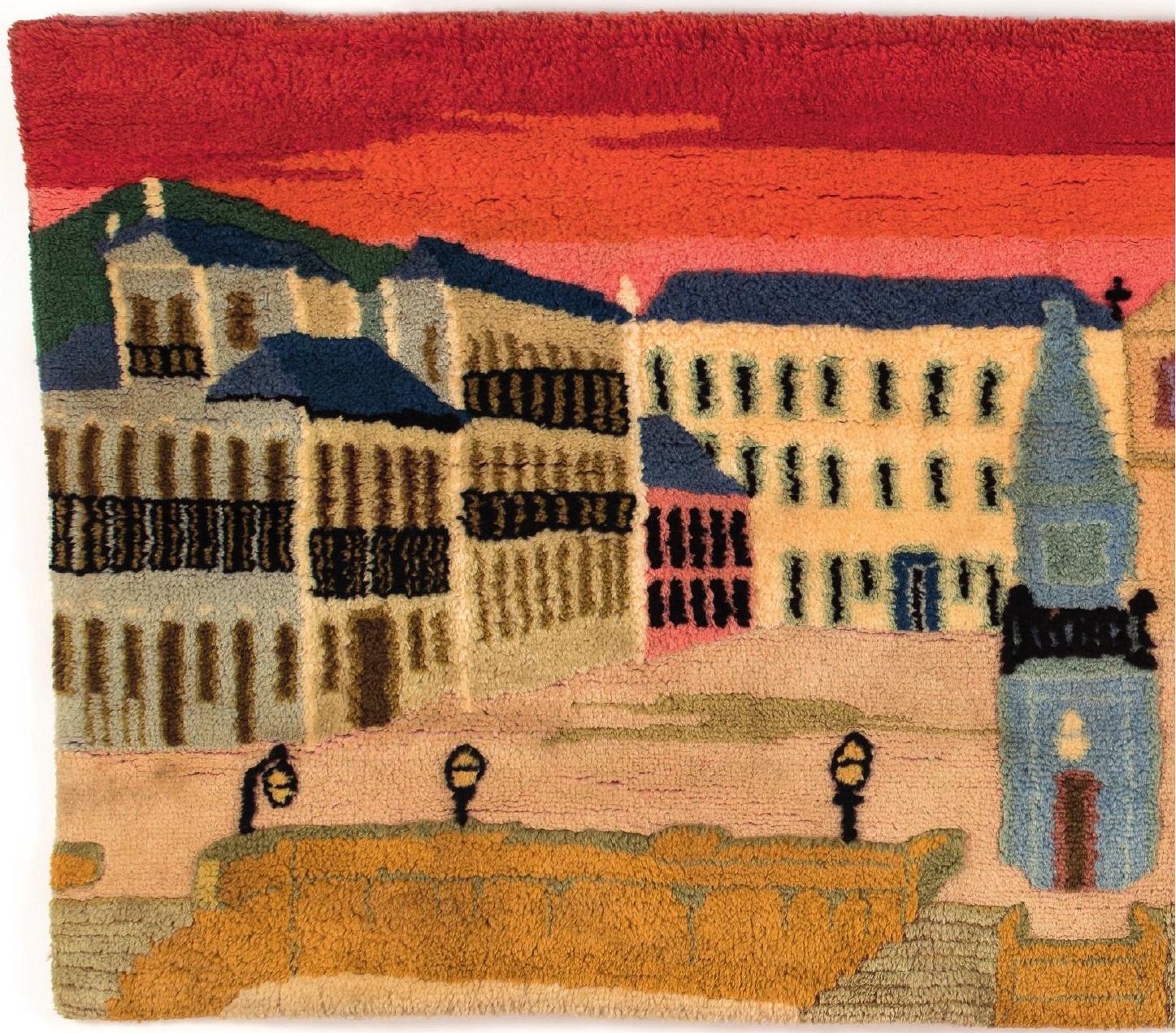




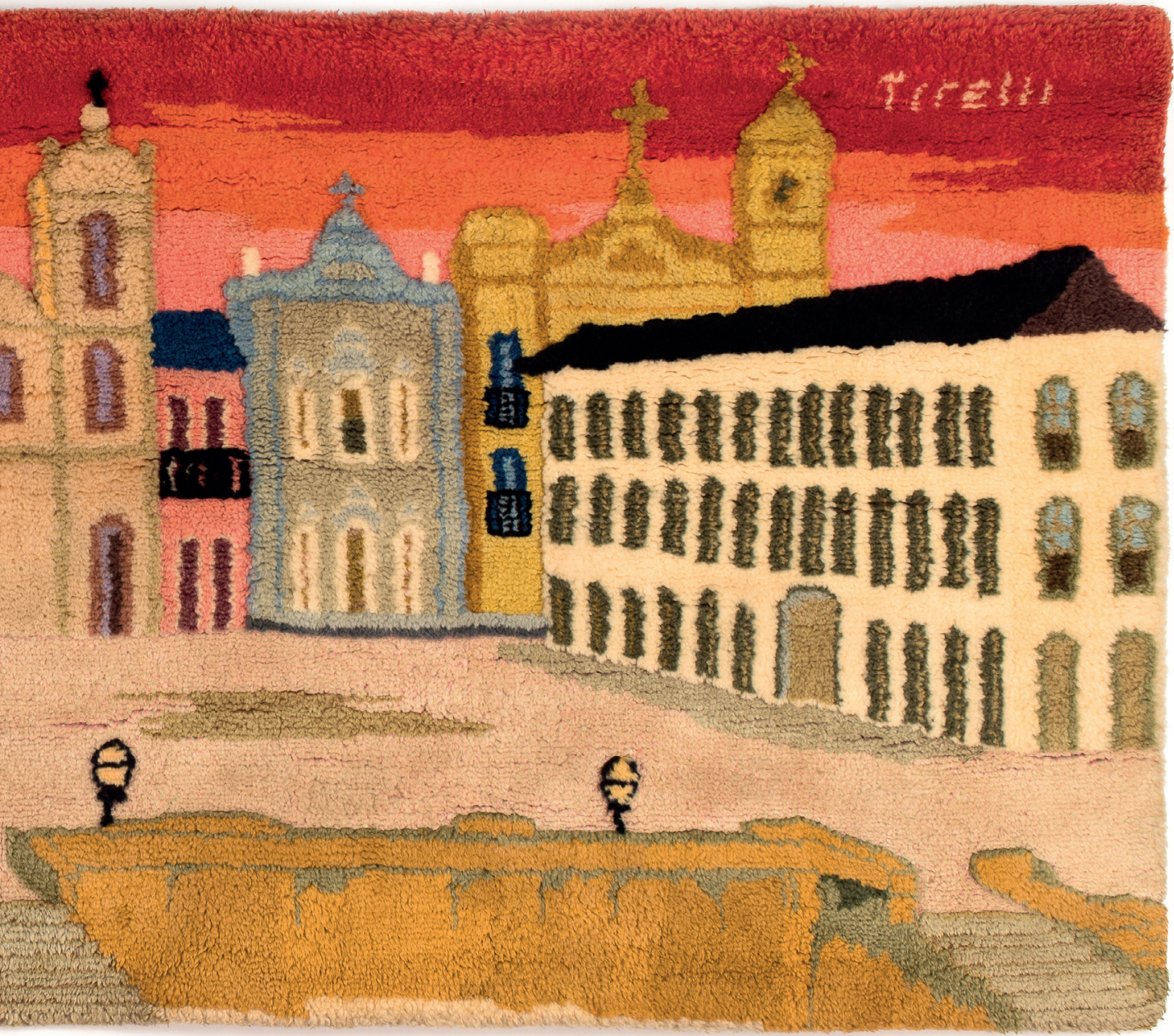

Figura 20 - Almir Tirelli Dias. 1975. Tapeçaria em lã. Dimensões: 1,37 m x 1,95 m. Proprietário: Fundação Catarinense de Cultura. Número de Tombo: 1-0064.0.71 (Patrimônio INFRAERO). Termo de doação em andamento. Foto: Carolina Rios (divulgação/FCCD). Fonte: Ficha Diagnóstico (ANEXO C). 
Concordo com o fato de que precisamos olhar para essas obras com muita atenção, olhar seus detalhes, pois um olhar rápido e desavisado não basta para compreender a grandiosidade do trabalho do artista. O que vemos nas tapeçarias remetem às nossas coisas e refletem nossas paixões. O palácio Cruz e Sousa, os rituais religiosos, os pescadores, a ponte Hercílio Luz, os manezinhos e suas brincadeiras, a renda de bilro, a Praça XV, a louça de barro, o pescador e sua tarrafa, nossas igrejas, o cortejo Imperial da Festa do Divino, o lampião de gás, tudo aparece e vai revelando-se à medida que os olhos percorrem a tela e podemos, com um olhar atento e desejoso, ver tudo isso que ali se anuncia. Tirelli conseguiu tecer, com delicadeza e precisão, registros históricos, lendas e o folclore da llha de Santa Catarina, seu casario colonial, sua alma.

Essas obras documentadas acima são as que retornaram para Santa Catarina e agora fazem parte do patrimônio do Estado. Todavia, fazendo pesquisa na internet (fonte maior dessa documentação), encontro mais um trabalho do tapeceiro, sem maiores dados, no Facebook de Nelson Silveira (2021). Constam as observações dos amigos: "O artista tinha uma casa linda aqui na Lagoa que não faz mais parte da história, uma pena. Cheguei a conhecê-lo". Outra:

Lá pela década de 90 fui com meus pais no Restaurante Oliveira com meus hidrocores e papéis. Uma hora chega um senhor e pergunta o que eu estava desenhando e desenha pra mim uma imagem de uma casa açoriana e me dá de presente. O senhor era o Tirelli.

A obra seguinte coloca em destaque um cenário muito apreciado pelos artistas e pelos ilhéus de Santo Antônio de Lisboa (Figura 21). 


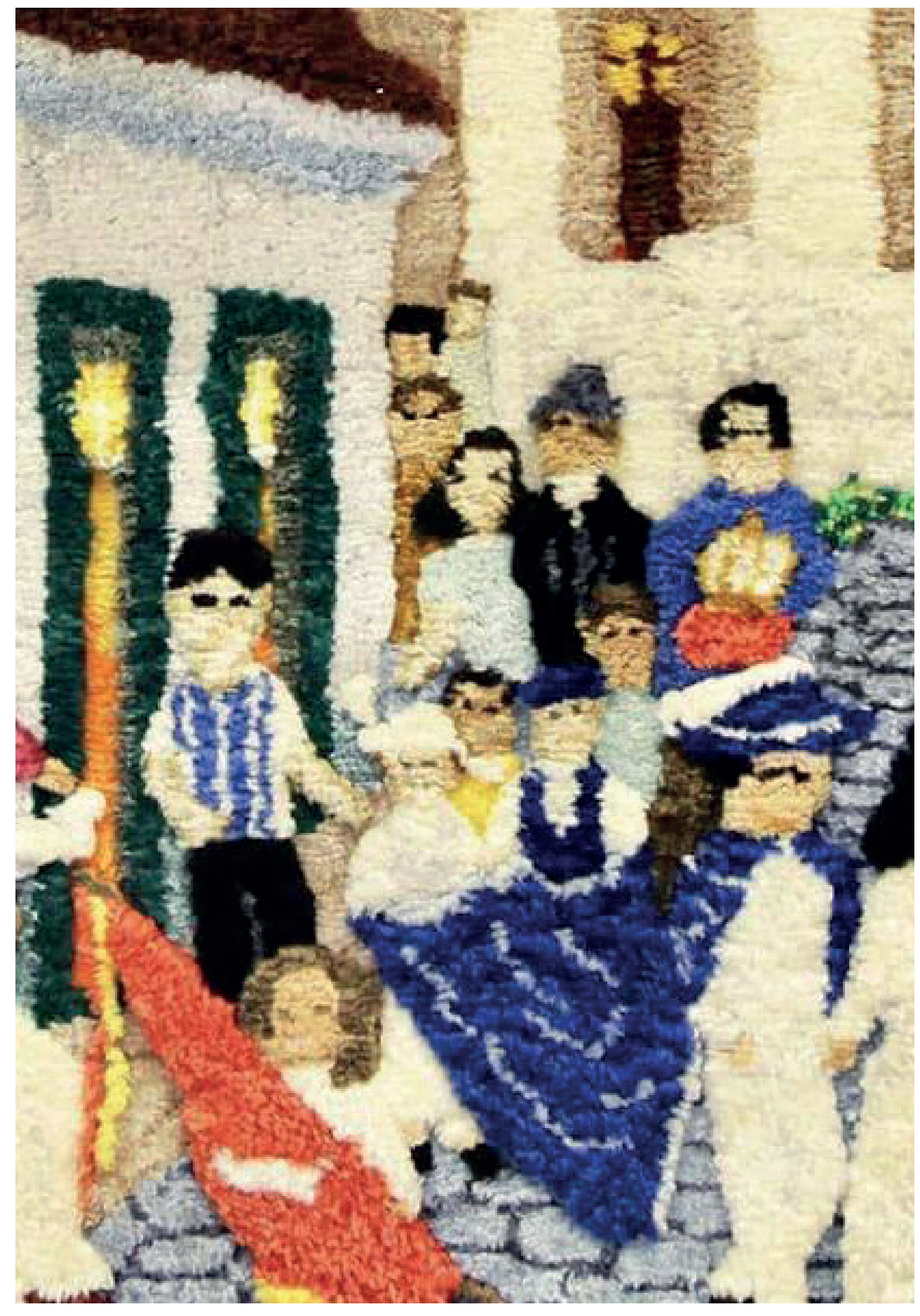

Detalha da obra, figura completa em página dupla nas páginas seguintes. Figura 21 - Almir Tirelli. Cortejo do Divino em Santo Antonio de Lisboa Fonte: Disponivel em: https://www.facebook.com/ photo?fbid=3636006366481244\&set=gm.2206192449524445. Acesso em: 20 mar. 2021. 

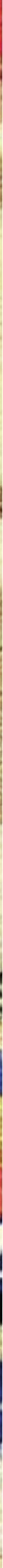

हf?
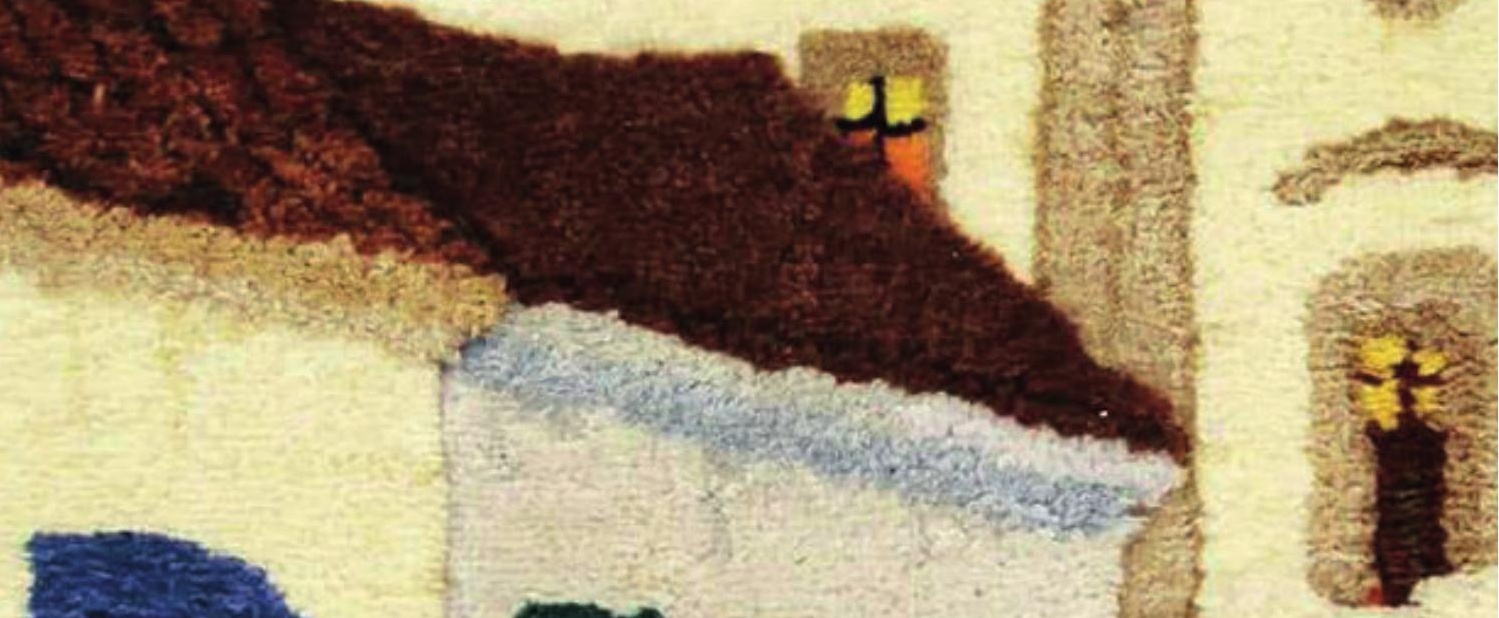
Por fim, no Google, anúncio de obras já vendidas em leilões. Interessanos o registro, na falta de outras obras (Figuras 22-23).

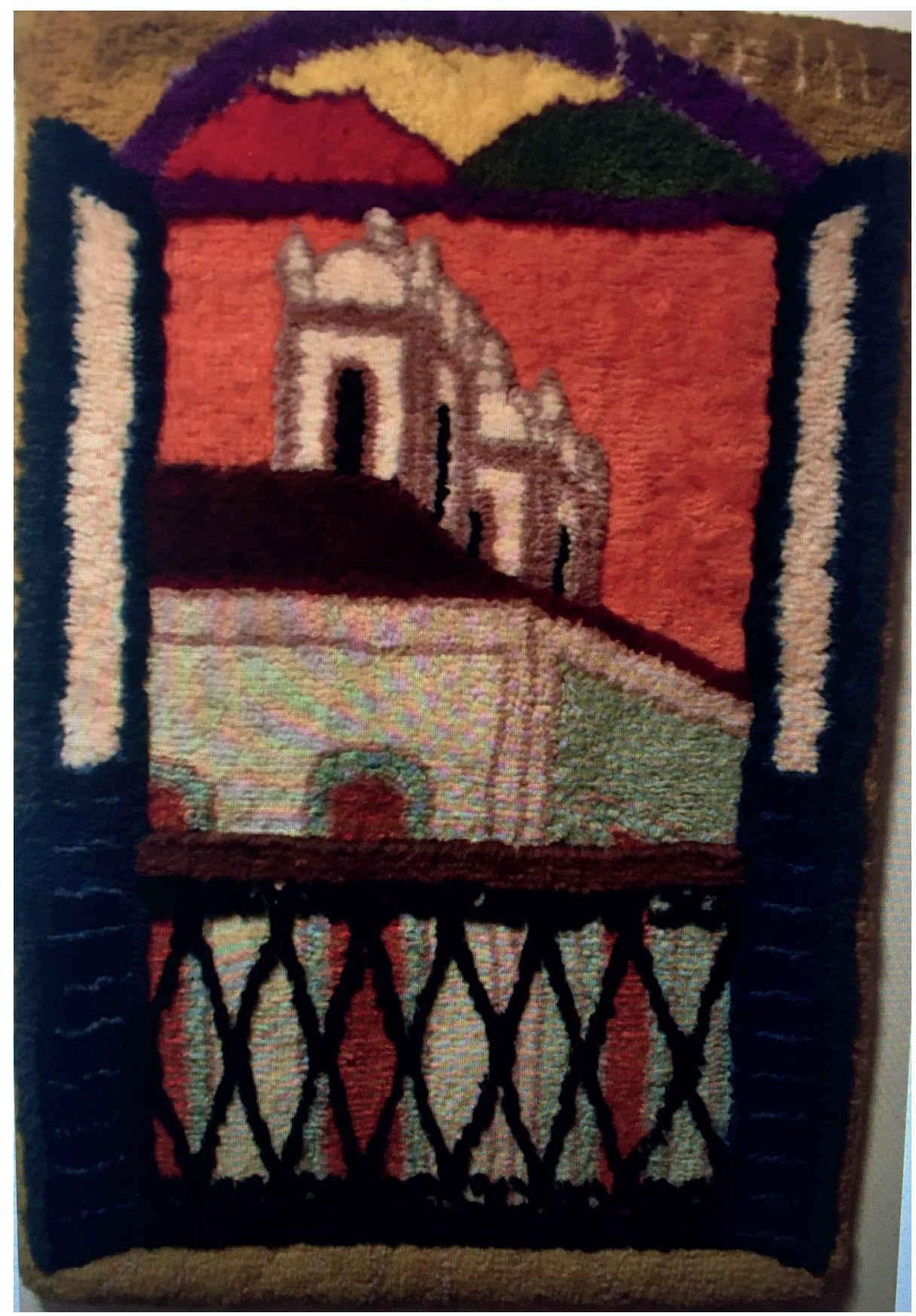

Figura 22 - Almir Tirelli. Palhoça, SC. 1982. 82 × 54 cm. Leilão realizado em 24/09/2020. Porto Alegre. Fonte: Disponível em: https://www.danielchaiebleiloeiro.com.br/peca. asp?ID=7528397. Acesso em: 10 mar. 2021. 


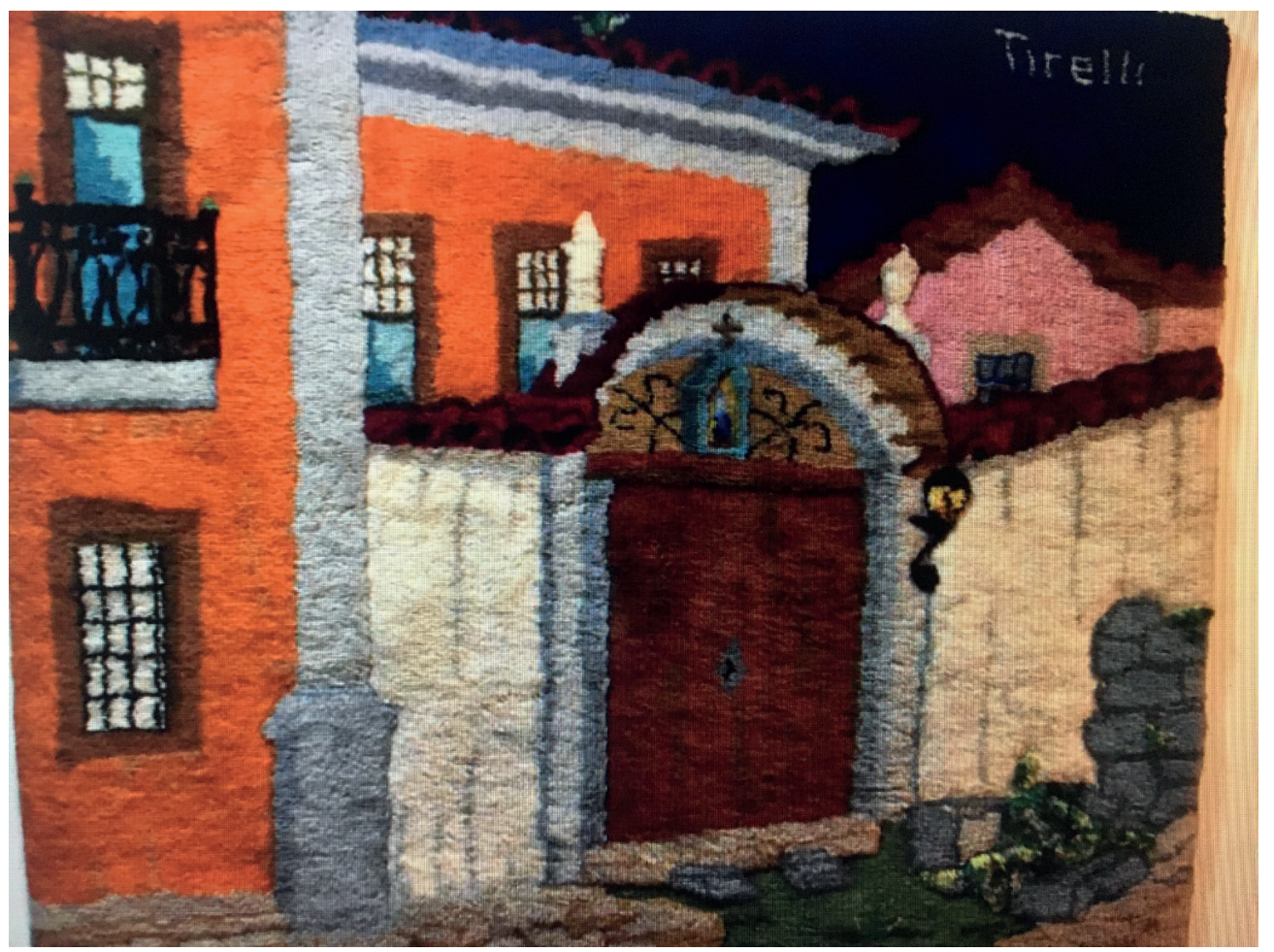

Figura 23 - Almir Tirelli. Tapeçaria. Lagoa da Conceição. 1980. 1,28 x 1,39 m. Leilão realizado em 24/09/2020, Porto Alegre.

Fonte: Disponivel em: https://www.danielchaiebleiloeiro.com.br/peca.asp?ID=7528397. Acesso em: 10 mar. 2021.

Outra obra à qual desejo dar destaque é um óleo sobre tela, que pertence ao acervo do colecionador Marcelo Collaço Paulo. Trata-se de uma tela que retrata a Rua Felipe Schmidt, tão cara aos florianopolitanos, em seus hábitos e costumes cotidianos (Figura 24).

Na tela, chamam a atenção os detalhes da figura 24, agora expostos na sequência das imagens (Figuras 24A a 24K). 
4
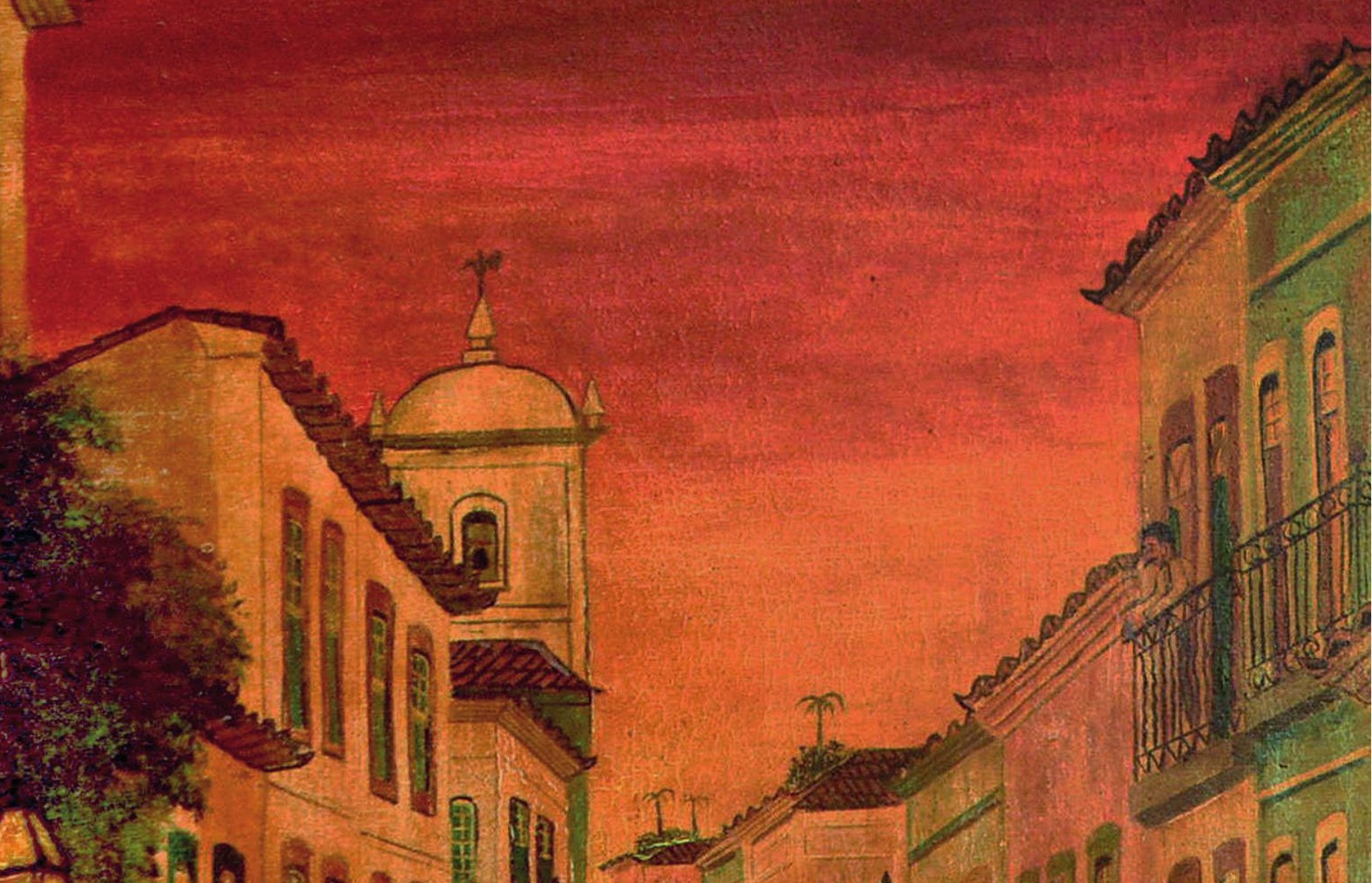
A) aur $x=4$

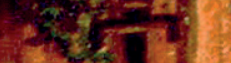

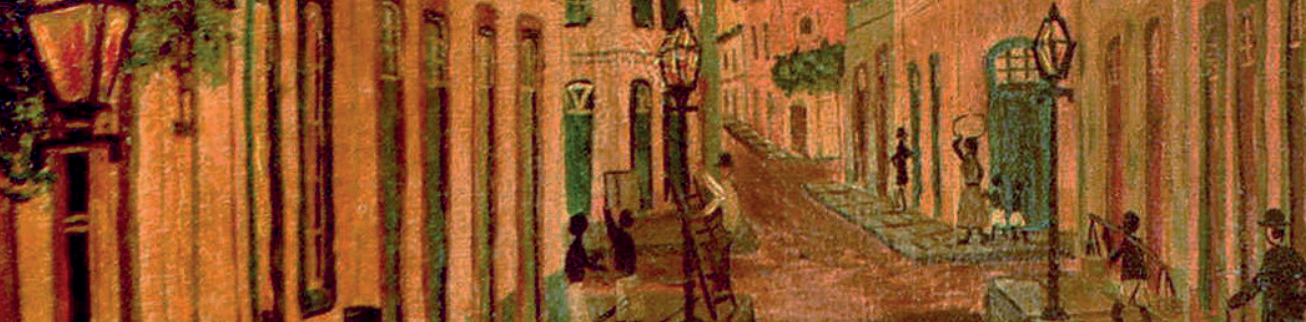

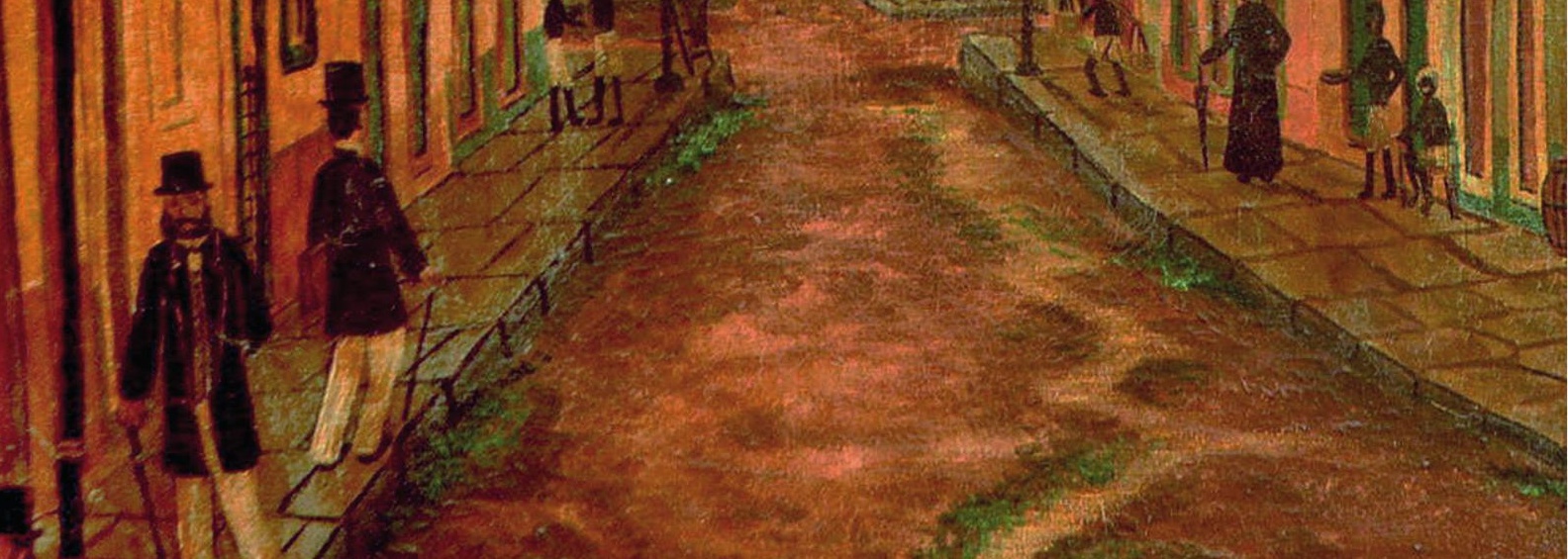




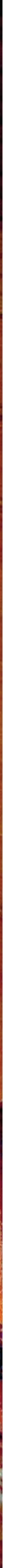




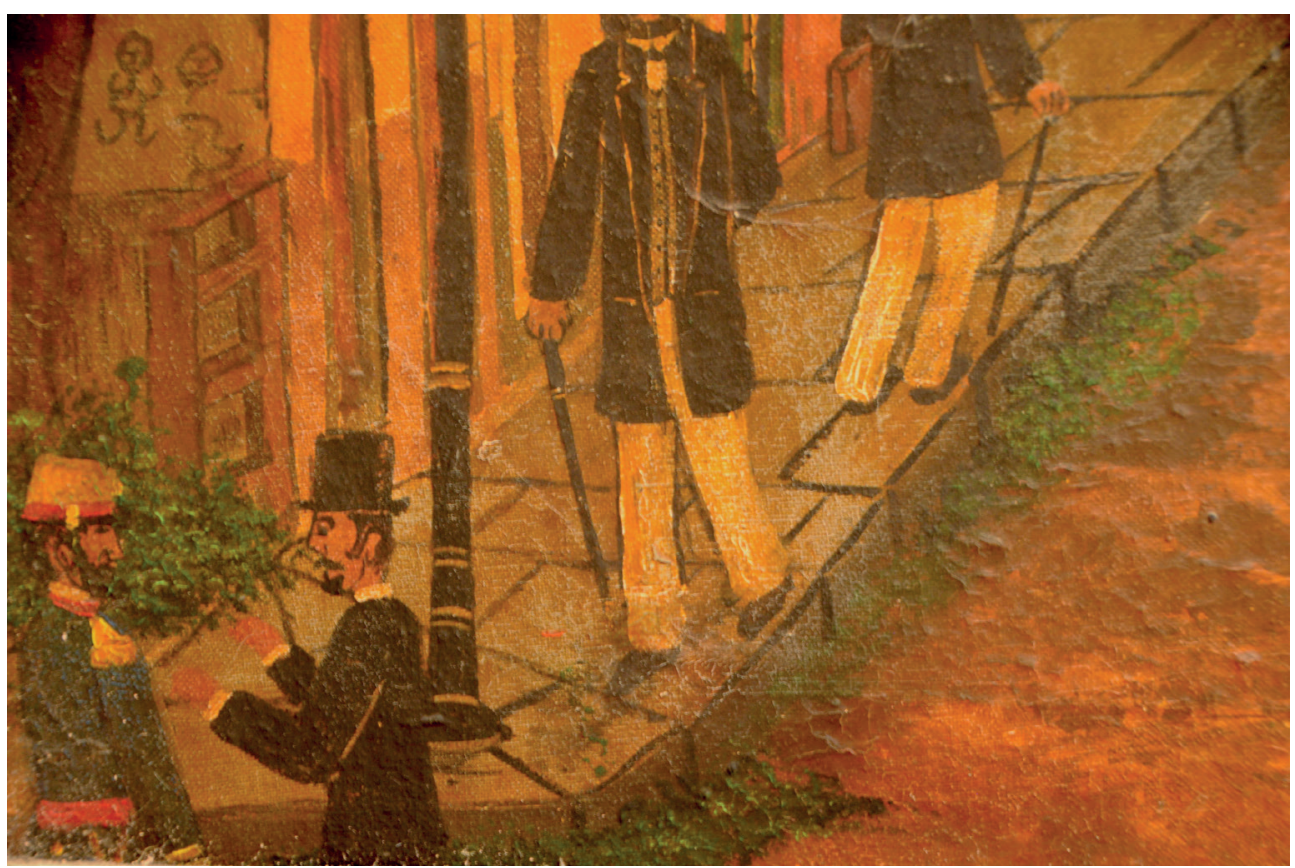

Figura 24 A - Almir Tireli. Rua Felipe Schmidt. Detalhe do canto inferior esquerdo. Óleo sobre tela. Dimensões: 1,33 m x 0,93 m. s.d. Coleção Marcello Collaço Paulo Fonte: Fotografia da autora.

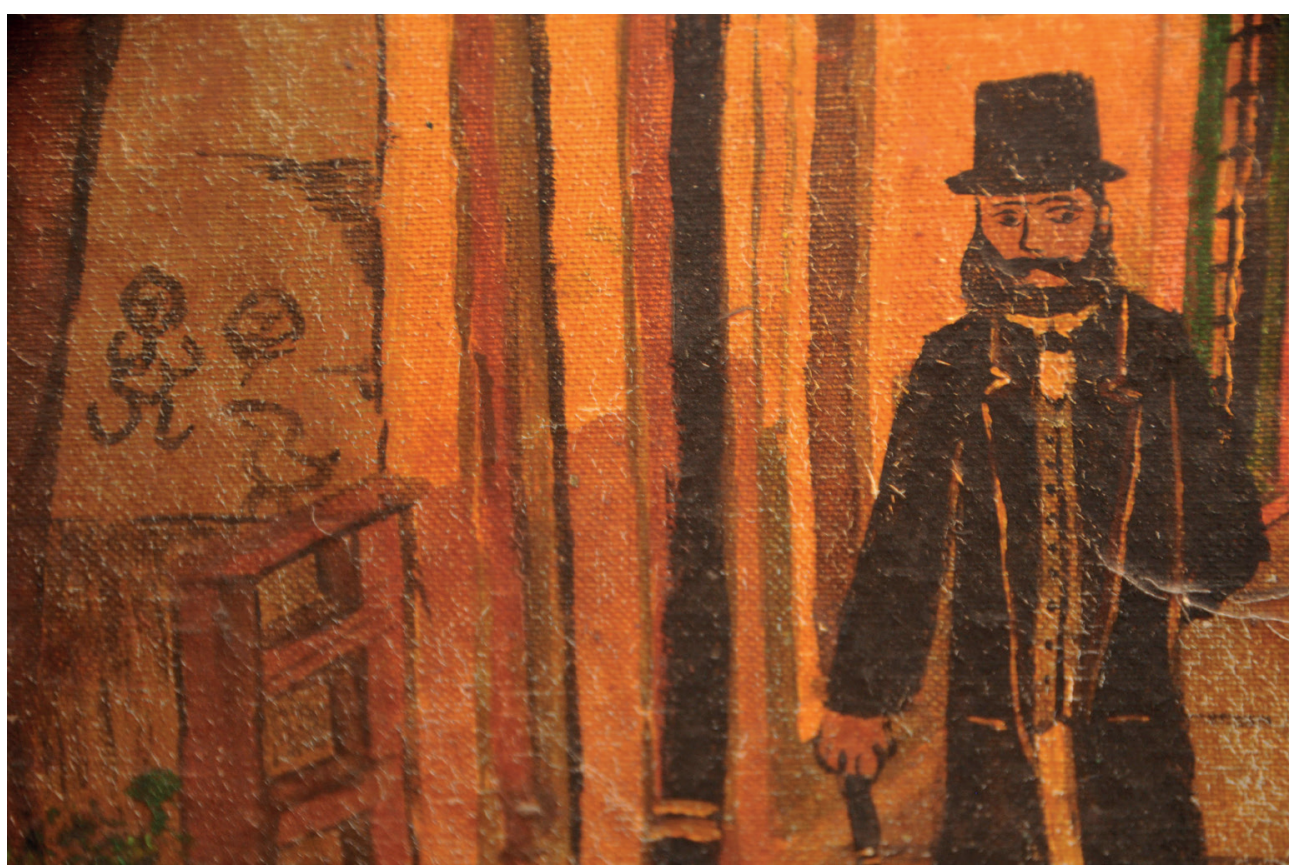

Figura 24B - Almir Tireli. Rua Felipe Schmidt. Detalhe do canto inferior esquerdo. Garatujas na parede. Óleo sobre tela. Dimensões: 1,33 m x 0,93 m. s.d. Coleção Marcello Collaço Paulo Fonte: Fotografia da autora. 


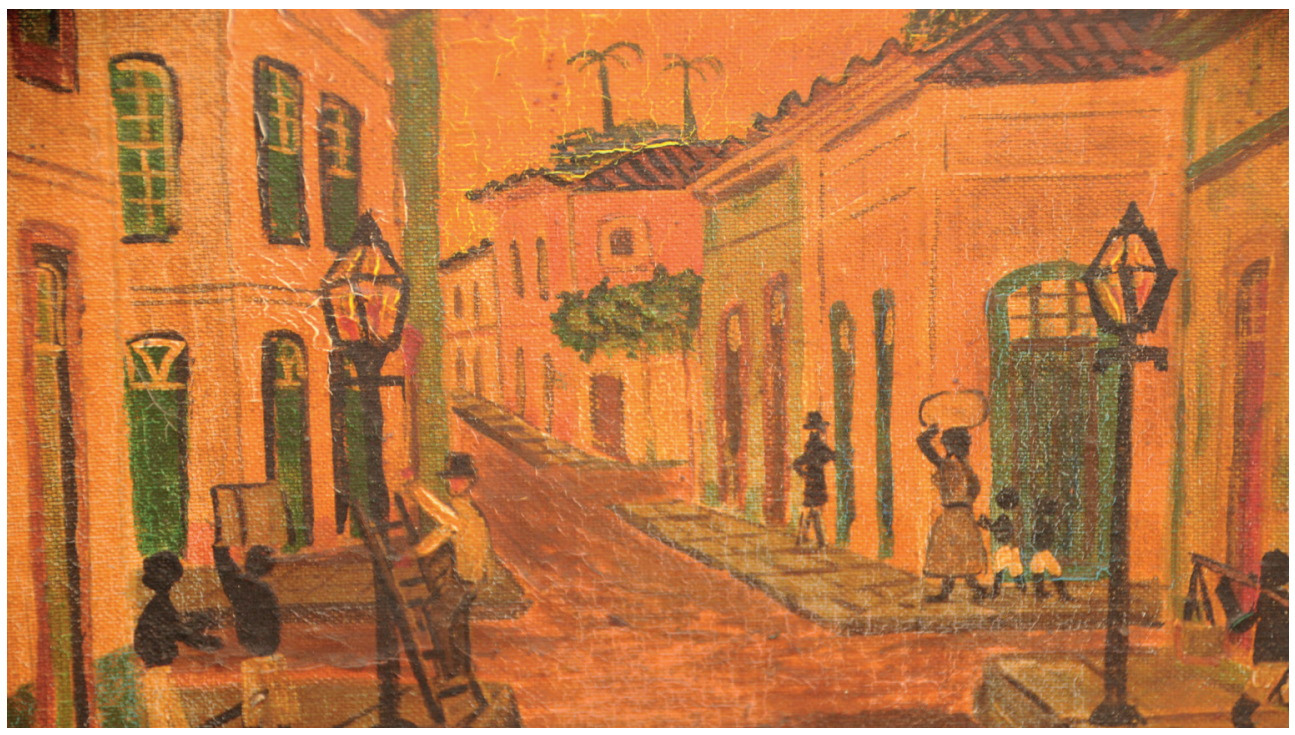

Figura 24C - Almir Tireli. Rua Felipe Schmidt. Detalhe do centro da composição, ao fundo. Óleo sobre tela. Dimensões: 1,33 m x 0,93 m. s.d. Coleção Marcello Collaço Paulo Fonte: Fotografia da autora.

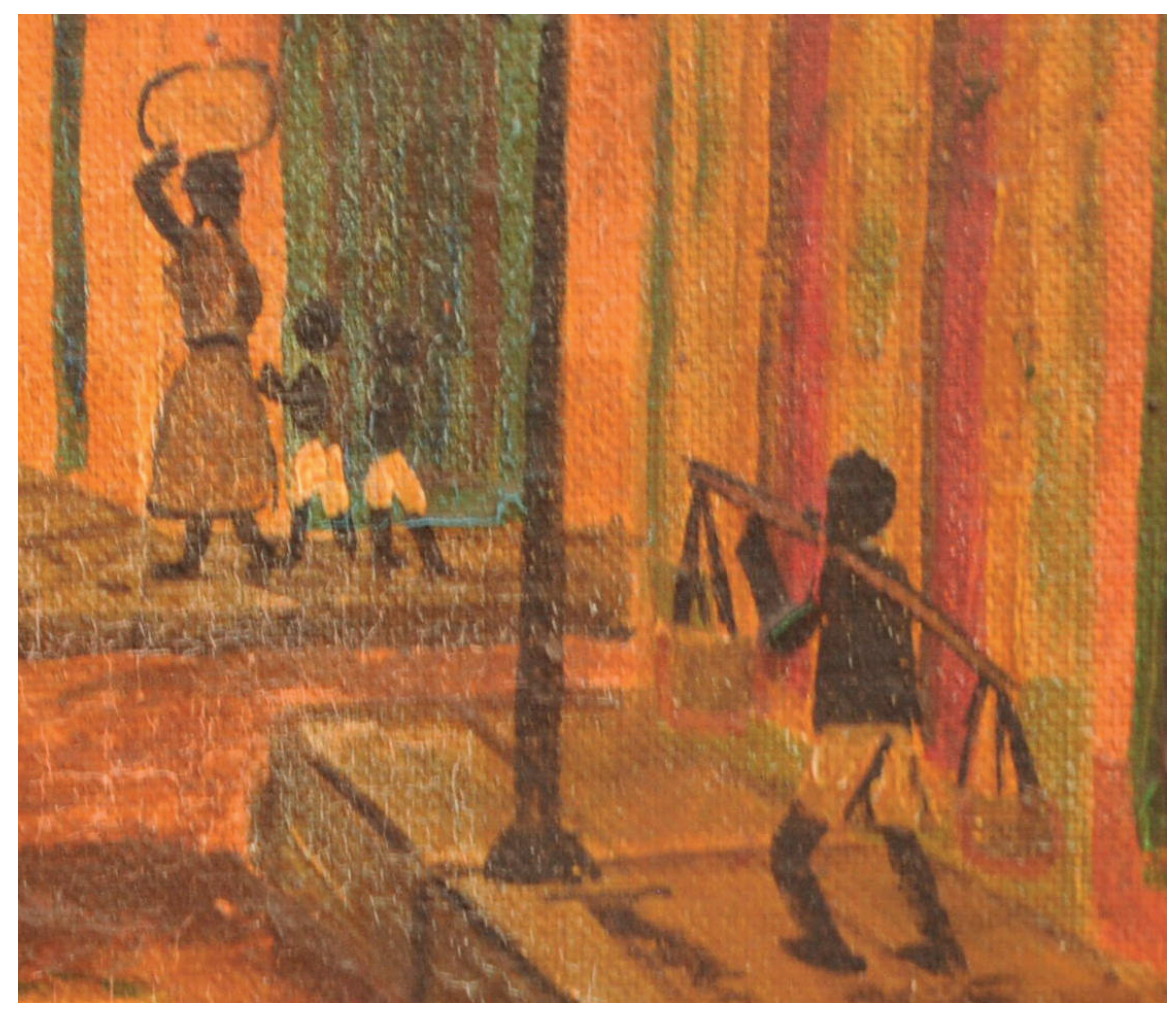

Figura 24D - Almir Tireli. Rua Felipe Schmidt. Detalhe do centro da composição, mulher com trouxa de roupa na cabeça e menino vendedor de amendoim torradinho. Óleo sobre tela. Dimensões: 1,33 m x 0,93 m. s.d. Coleção Marcello Collaço Paulo. Fonte: Fotografia da autora. 


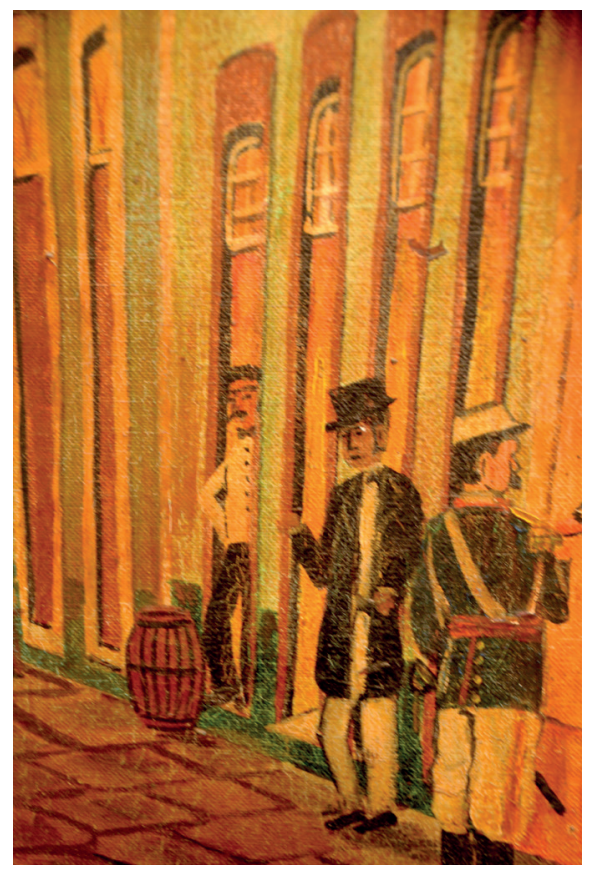

Figura 24E - Almir Tireli. Rua Felipe Schmidt. Detalhe do lado direito da composição.

Óleo sobre tela. Dimensões: 1,33 m x 0,93 m. s.d. Coleção Marcello Collaço Paulo Fonte: Fotografia da autora.

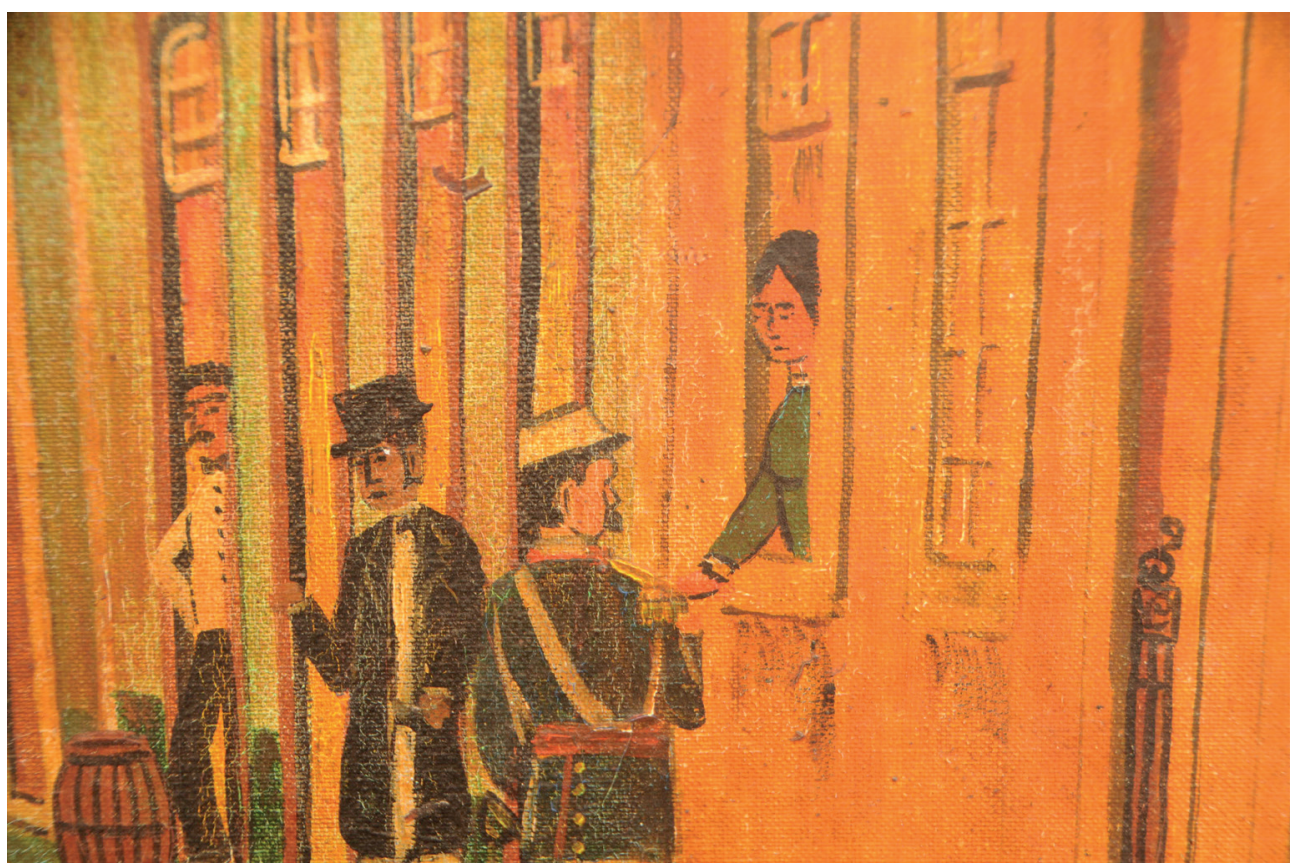

Figura 24F - Almir Tireli. Rua Felipe Schmidt. Detalhe do lado direito da composição. Óleo sobre tela. Dimensões: 1,33 m x 0,93 m. s.d. Coleção Marcello Collaço Paulo Fonte: Fotografia da autora. 


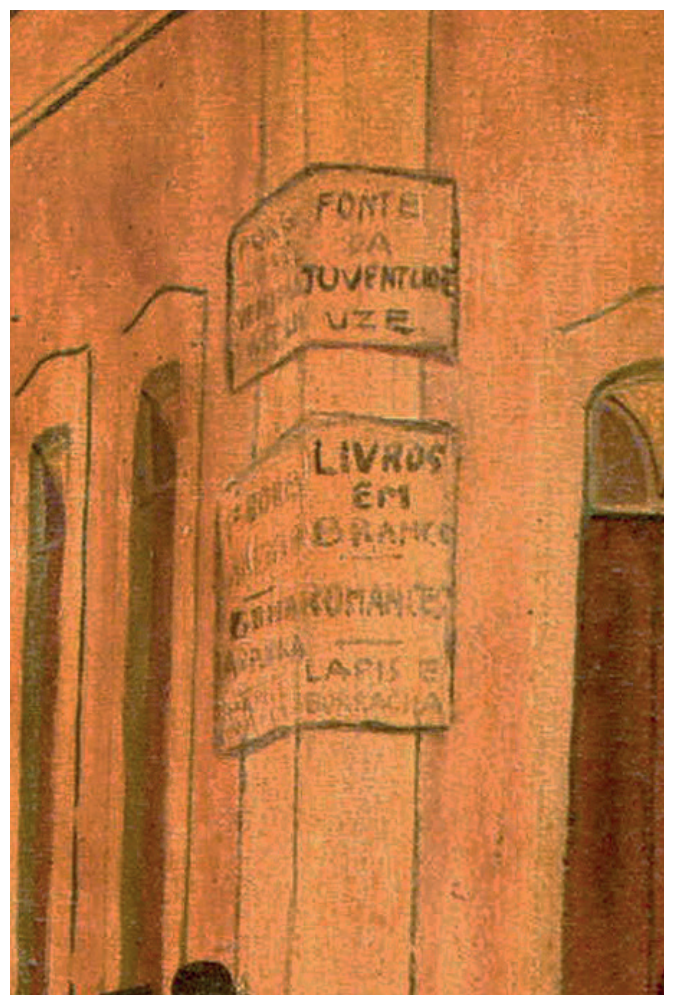

Figura 24G - Almir Tireli. Rua Felipe Schmidt. Detalhe do lado direito da composição, com identificação na parede. Óleo sobre tela. Dimensões: 1,33 m x 0,93 m. s.d. Coleção Marcello Collaço Paulo

Fonte: Fotografia da autora.

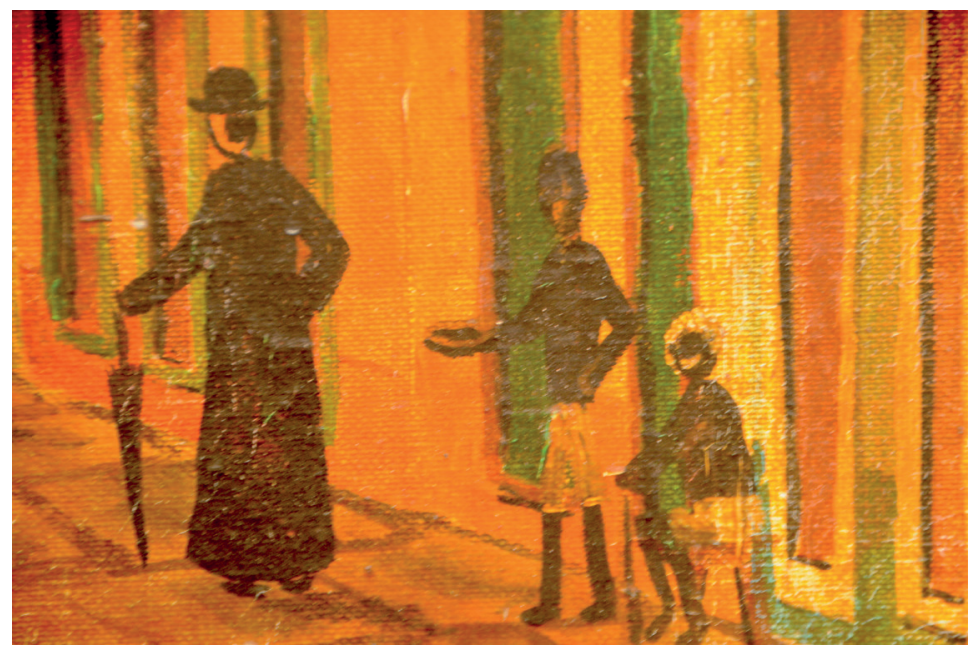

Figura 24H - Almir Tireli. Rua Felipe Schmidt. Detalhe do lado direito da composição. Padre passando e crianças pedindo esmola. Óleo sobre tela. Dimensões: 1,33 m x 0,93 m. s.d. Coleção Marcello Collaço Paulo. Fonte: Fotografia da autora. 


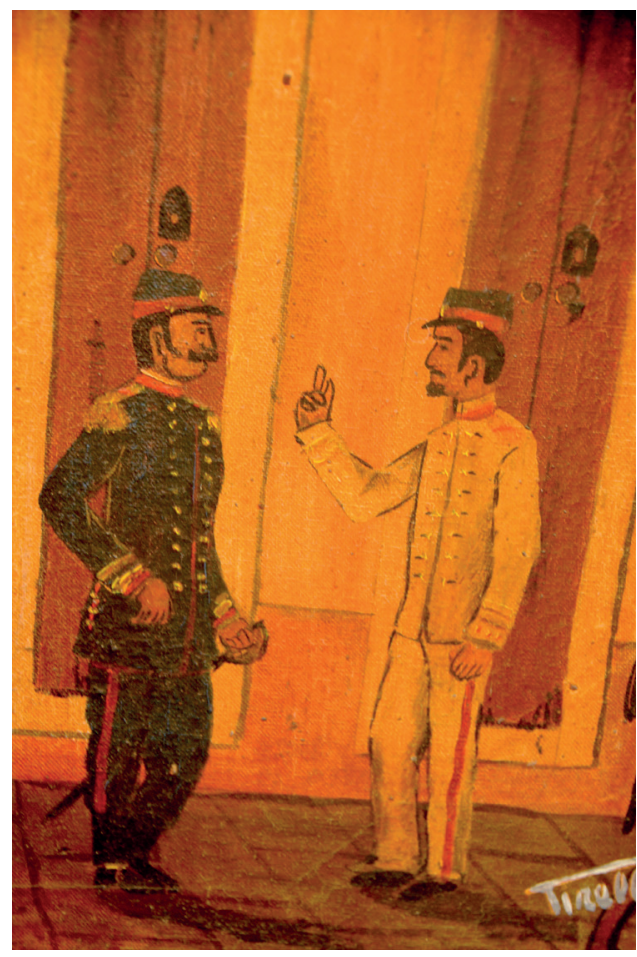

Figura 241 - Almir Tireli. Rua Felipe Schmidt. Detalhe do lado direito da composição. Soldados conversando. Óleo sobre tela. Dimensões: 1,33 m x 0,93 m. s.d. Coleção Marcello Collaço Paulo. Fonte: Fotografia da autora.

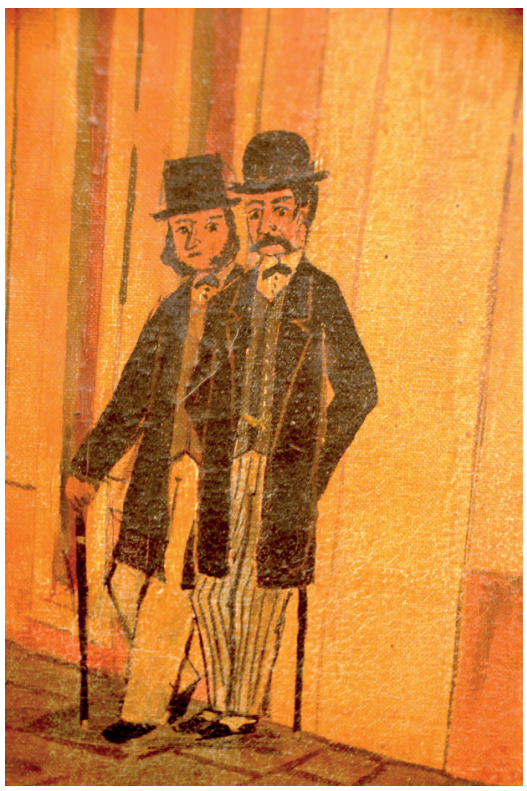

Figura 24J - Almir Tireli. Rua Felipe Schmidt. Detalhe do lado direito da composição. Óleo sobre tela. Dimensões: 1,33 m x 0,93 m. s.d. Coleção Marcello Collaço Paulo. Fonte: Fotografia da autora. 


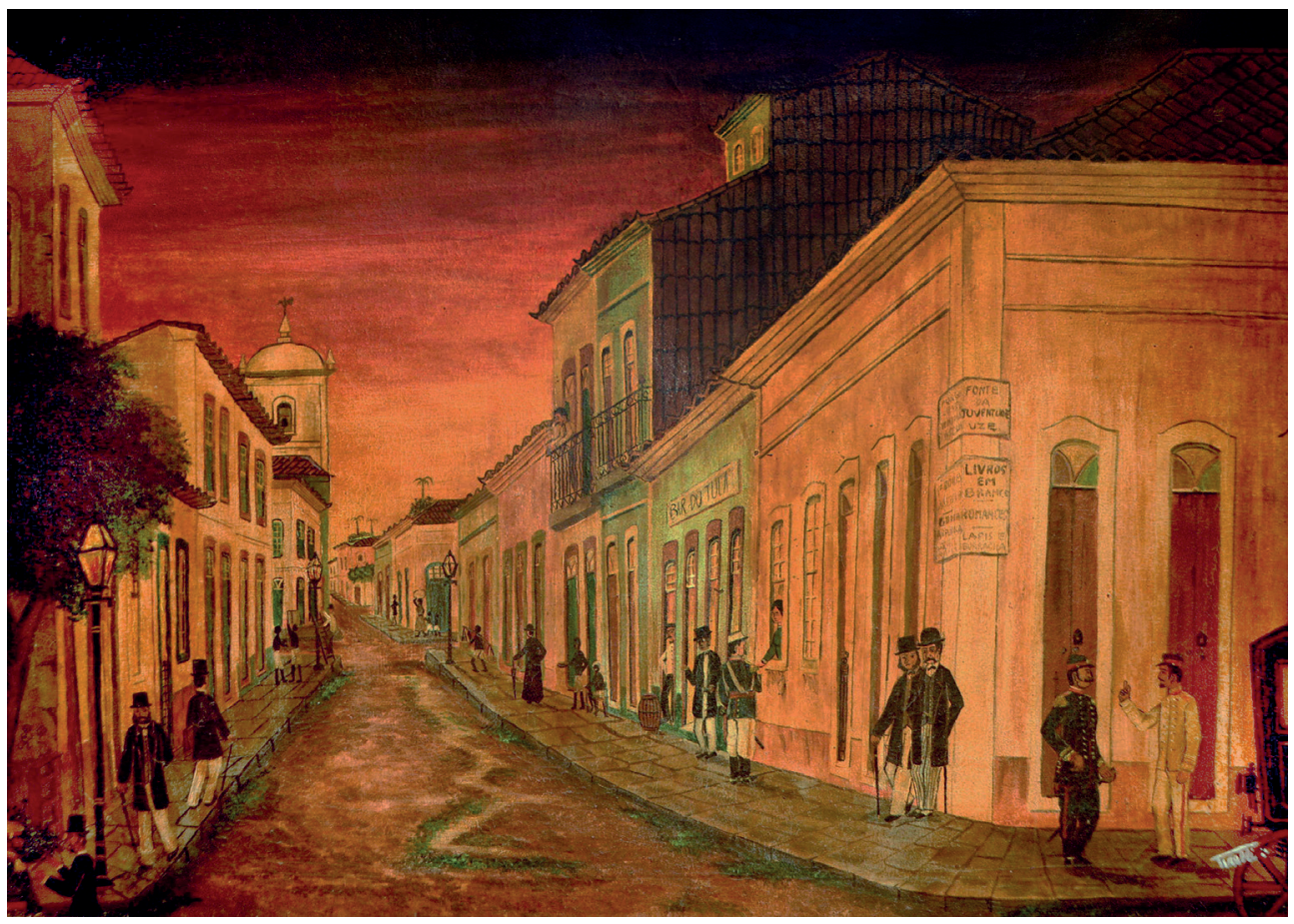

Figura 24K - Almir Tireli. Rua Felipe Schmidt. Óleo sobre tela. Dimensões: 1,33 m x 0,93 m. s.d. Coleção Marcello Collaço Paulo. Fonte: Fotografia da autora.

No quadro, vemos um artista que nos mostra a cidade de Florianópolis. Visto de nossa atual perspectiva, o primeiro impacto desse quadro é a constatação do quanto mudaram as coisas. E, por outro lado, é notável constatar que algumas coisas não são tão diferentes assim. A igreja de São Francisco de Assis da Penitência permanece com sua torre alta. Rafael Cardoso, ao analisar um outro quadro com essas mesmas características, escreveu: "Talvez resida aí uma lição importante para quem quer entender a alma do país. Por mais que mudem as aparências, permanecem os hábitos" (CARDOSO, 2008, p. 21). A obra mostra aspectos históricos da cidade de Florianópolis, tendo como mote uma obra plástica, que pode ter sido elaborada a partir de fotografias de época.

Vemos crianças passeando com uma mulher que leva trouxa de roupa na cabeça (Figuras 24C e 24D), o menino que vende amendoim torradinho, hábito comum à época (Figura 24D), um homem apoiado em uma escada no poste para mexer na luz (Figura 24C), dois homens com uniforme conversam Figura 24I), outros observam (Figura 24J), outros apenas caminham (Figura 24A). Vemos um padre caminhando e, perto dele, crianças pedindo esmola com chapéu em punho (Figura $24 \mathrm{H}$ ), os cartazes identificando a loja na esquina (Figura 24G), homens conversando e paredes com garatujas, que poderiam ser a versão da época dos pichadores 
atuais (Figuras 24A e 24B). Outro hábito bastante comum era a conversa através da janela com transeuntes (Figura 24F). Portanto, percebem-se costumes, estilos, leituras e também hábitos provincianos. Havia uma tentativa pessoal de documentação. Pode ser que algumas das figuras retratadas correspondam a personagens conhecidos na cidade, mas não dispomos de dados para afirmar. Se foi o caso, tal aspecto remete-nos ao gênero conhecido como costumbrismo, que é a interpretação literária ou pictórica da vida cotidiana, maneirismos e costumes locais, principalmente no cenário hispânico e, particularmente, no século XIX. As cenas são múltiplas e desdobram-se ao longo da tela, em simultaneidade: crianças caminham, cavalheiros conversam na rua, e, em suas janelas, pessoas observam. Nesse quadro, como em alguns de Eduardo Dias, percebese uma combinação entre a tentativa de aproximação com os preceitos clássicos e o efeito lírico e ingênuo. Nos quadros de casas açorianas e nas paisagens urbanas, há também uma aproximação ao olhar panorâmico dos cartões-postais, das fotografias ou das observações in loco. Essa obra torna-se valiosa como registro de uma época, de registro da cidade, de pessoas, hábitos, um documento histórico a ser analisado em símbolos e imagens. $O$ casarão da esquina à direita da imagem em Tirelli (Figura 24, p. 50-51) já foi retratado por Martinho de Haro (Figura 25) e Eduardo Dias (Figura 26), em obras magistrais, e serão incluídas como um registro também histórico, que é um dos grandes méritos das obras. No caso das telas citadas, a esquina seria a do meio da tela e no meio da praça. Em Martinho, perto dos cavalos e charrete, e em Eduardo Dias, bem na altura do cortejo. A obra de Eduardo Dias (Figura 26) foi doada ao Museu de Arte de Santa Catarina por Jeanine e Marcelo Collaço Paulo, em 25 de outubro de 2017, em outra ação de mecenato registrada neste trabalho, tal como aconteceu com as tapeçarias de Almir Tirelli que estavam no aeroporto Hercílio Luz. 


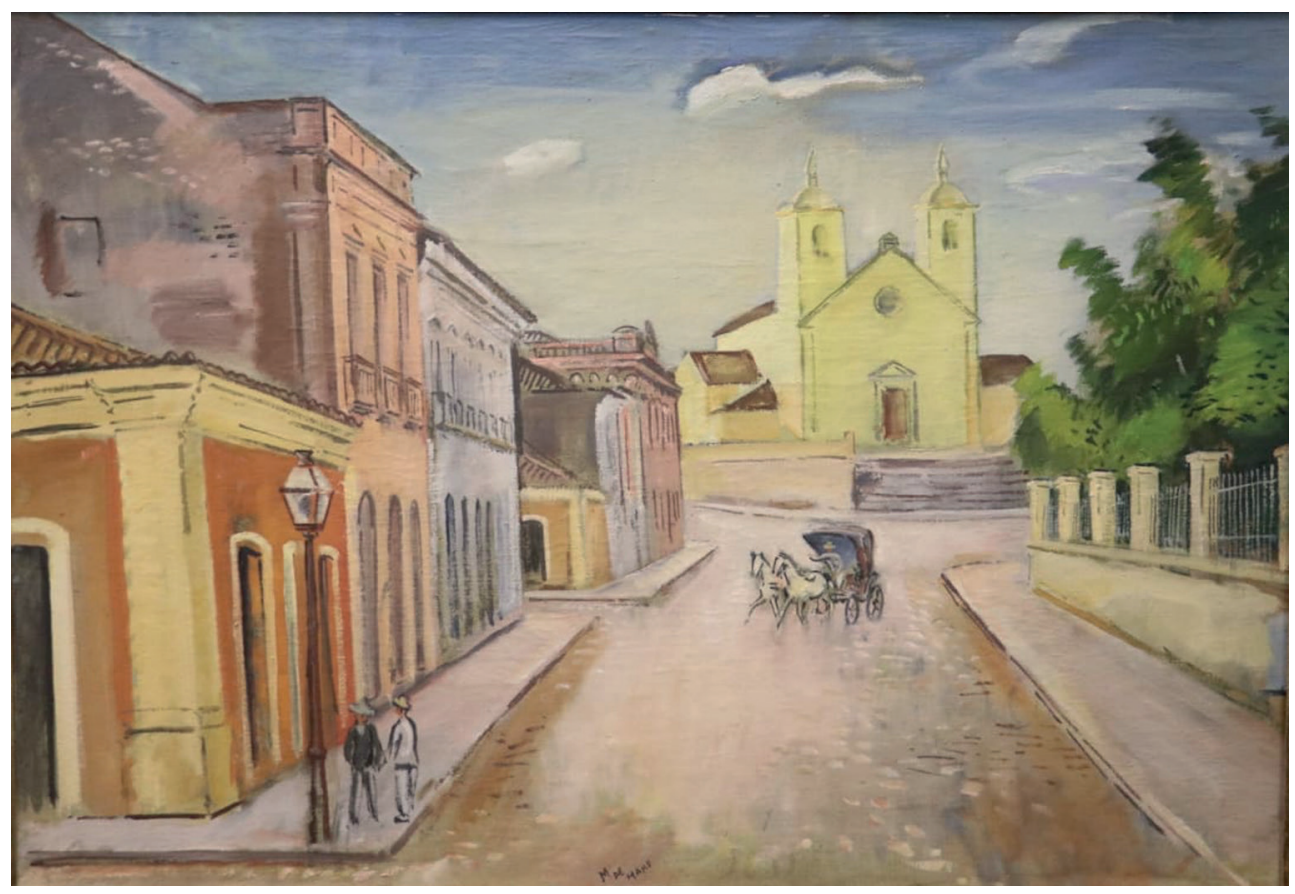

Figura 25 - Martinho de Haro. Sem título. S/d. Óleo sobre tela. $57 \times 75 \mathrm{~cm}$. Acervo da Assembleia Legislativa do Estado de Santa Catarina (ALESC)

Fonte: ALESC.

Em Martinho de Haro, nosso excepcional modernista, o silêncio é como uma saudade de pedra, em que o som reverbera em nossa mente, pelo barulho dos cascos dos cavalos no chão. Em Eduardo Dias, uma gama variada de pessoas: homens públicos, damas da sociedade, homens do povo, mendigos, animais e crianças. "Nas grandes cidades a rua passa a criar o seu tipo, a plasmar o moral dos seus habitantes, a inocular-lhes misteriosamente gostos, costumes, hábitos, opiniões políticas" (ANTELO, 1997, p. 67). O artista, nessa obra e em outras, transforma as ruas em cenários para conter a memória de um instante vivido (MAKOWIECKY, 2019). Os transeuntes são testemunhos do cotidiano urbano, assim como na obra de Almir Tirelli. 


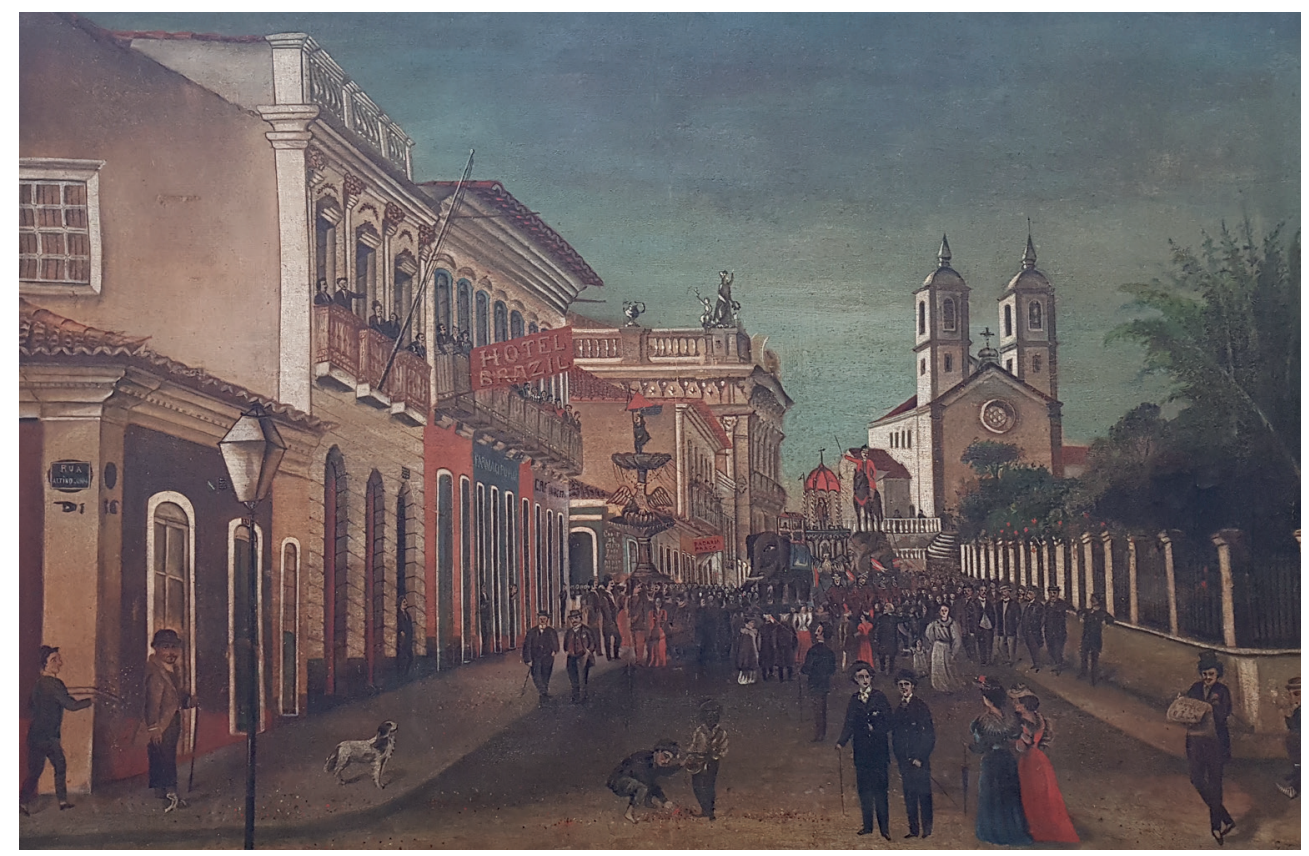

Figura 26 - Eduardo Dias. Netos do Diabo, também conhecida como Carnaval. s/d. Óleo sobre tela 115 × 75 cm. Acervo do Museu de Arte de Santa Catarina

Fonte: Fotografia da autora.

\section{EPISÓDIO NUMERO 6 - A MONTAGEM DA EXPOSIÇÃO EM 2021}

Este episódio trata de montagem da exposição no Museu Histórico de Santa Catarina (MHSC).

Como já dito, recebi convite para fazer um texto de apresentação da exposição que abrirá ao público, exibindo as tapeçarias que retornaram para Santa Catarina, por parte de Lena Peixer, diretora do Museu Histórico de Santa Catarina (MHSC). O MHSC está sob coordenação da Fundação Catarinense de Cultura (FCC), sob a presidência de Ana Lúcia Coutinho. A ambas, agradeço a confiança da pesquisa e da autonomia em redigir o texto.

No mês de fevereiro, iniciam-se os preparativos para a exposição ao público das tapeçarias de Almir Tirelli que estavam no aeroporto Hercílio Luz, agora de volta ao lar, sob os cuidados da FCC. 
O filho a casa tornou, finalmente.

Recebi de Lena Peixer umas fotografias do processo de embalagem, transporte, montagem. São imagens que não foram feitas para divulgação, mas, na ânsia de conseguir imagens e escrever esta história, eu as coloco no texto. Não posso esconder certo orgulho ao perceber o cuidado, o carinho e o respeito pelas obras. As fotos também são importantes para fornecer dimensão de escala (Figuras 27 a 37).

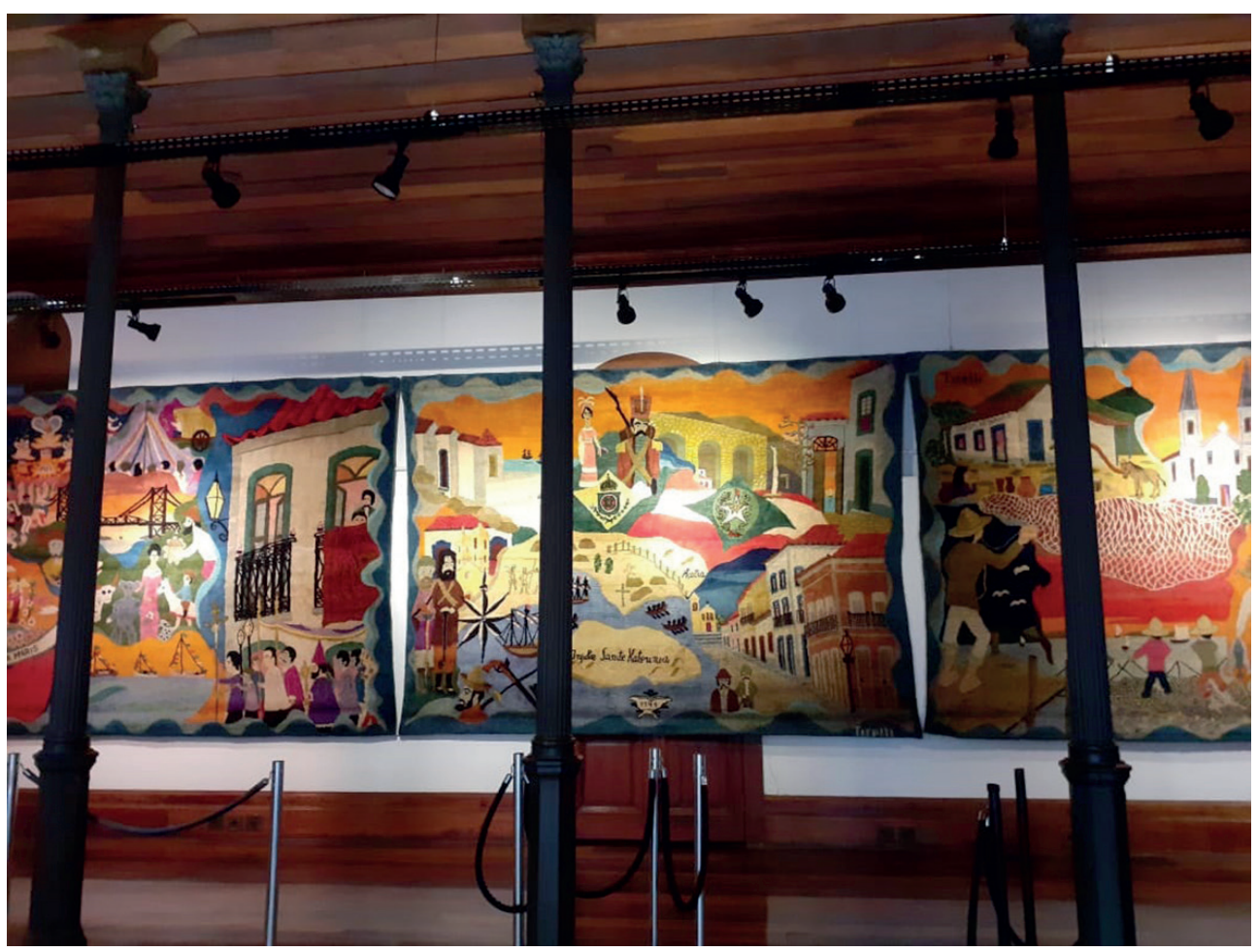

Figura 27 - Montagem no MHSC. Fevereiro/março de 2021. Visão frontal. Foto: Lena Peixer Fonte: Fotografia de Lena Peixer. 


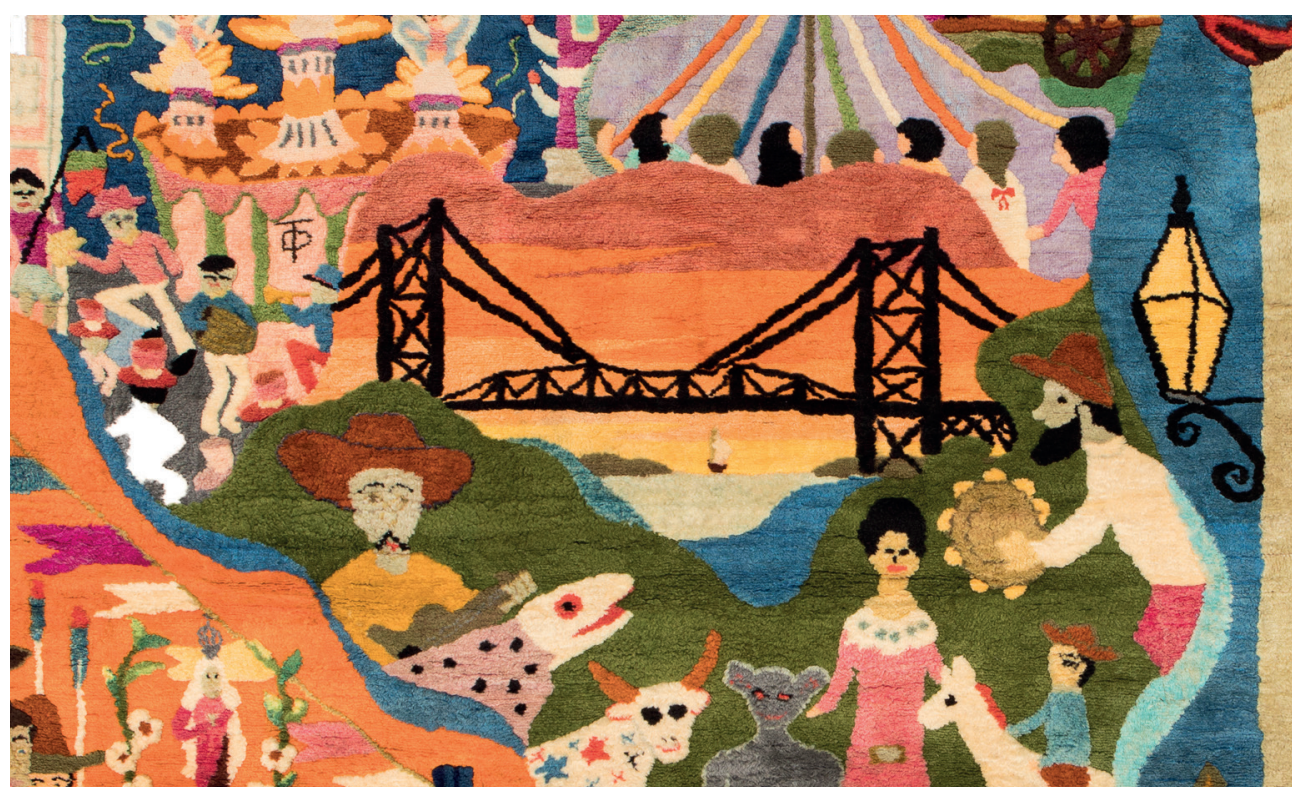

Figura 28 - Detalhe do painel 1. Almir Tirelli Dias. 1974. Tapeçaria em lã. Dimensões: 2,95 m x 4, $05 \mathrm{~m}$.

Proprietário: Fundação Catarinense de Cultura. Número de Tombo: 1-0064.7.62 Fonte: Fotografia de Carlos Pontalti.

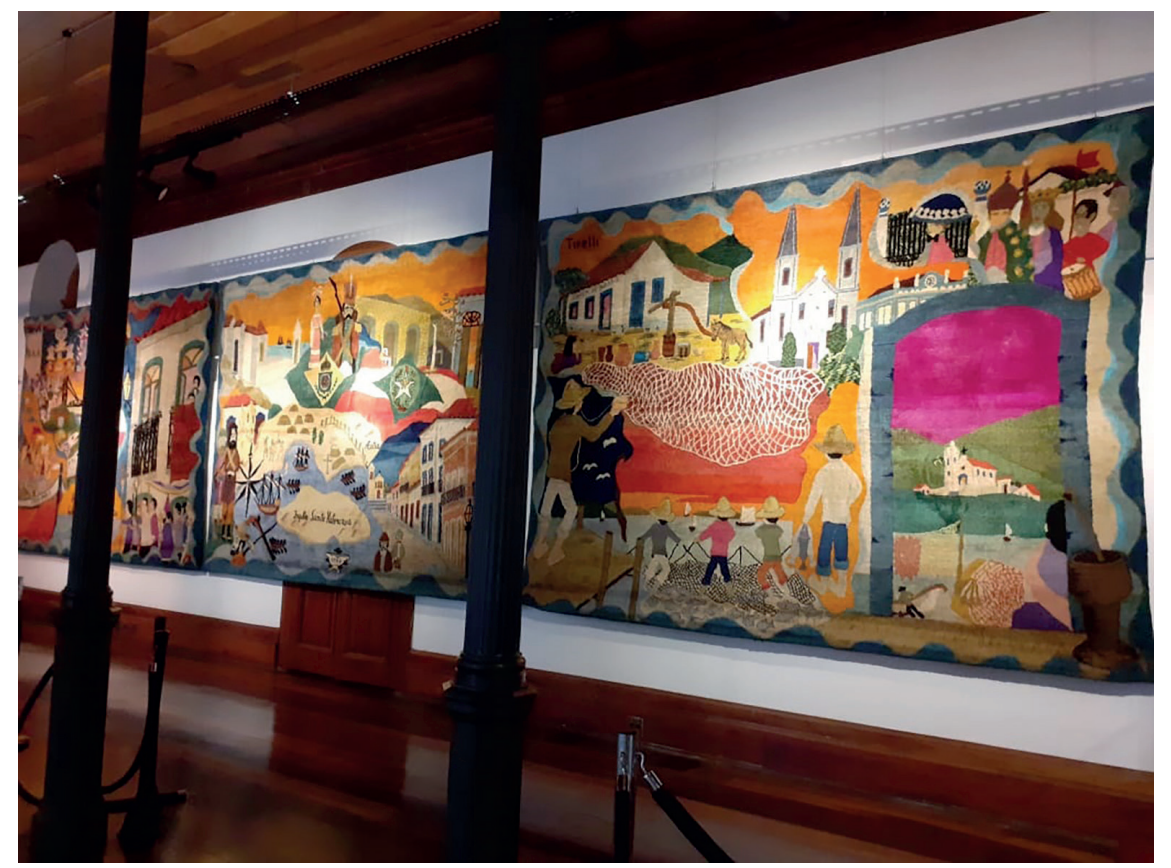

Figura 29 - Montagem no MHSC. Fevereiro/março de 2021. Foto: Lena Peixer Fonte: Fotografia de Lena Peixer. 


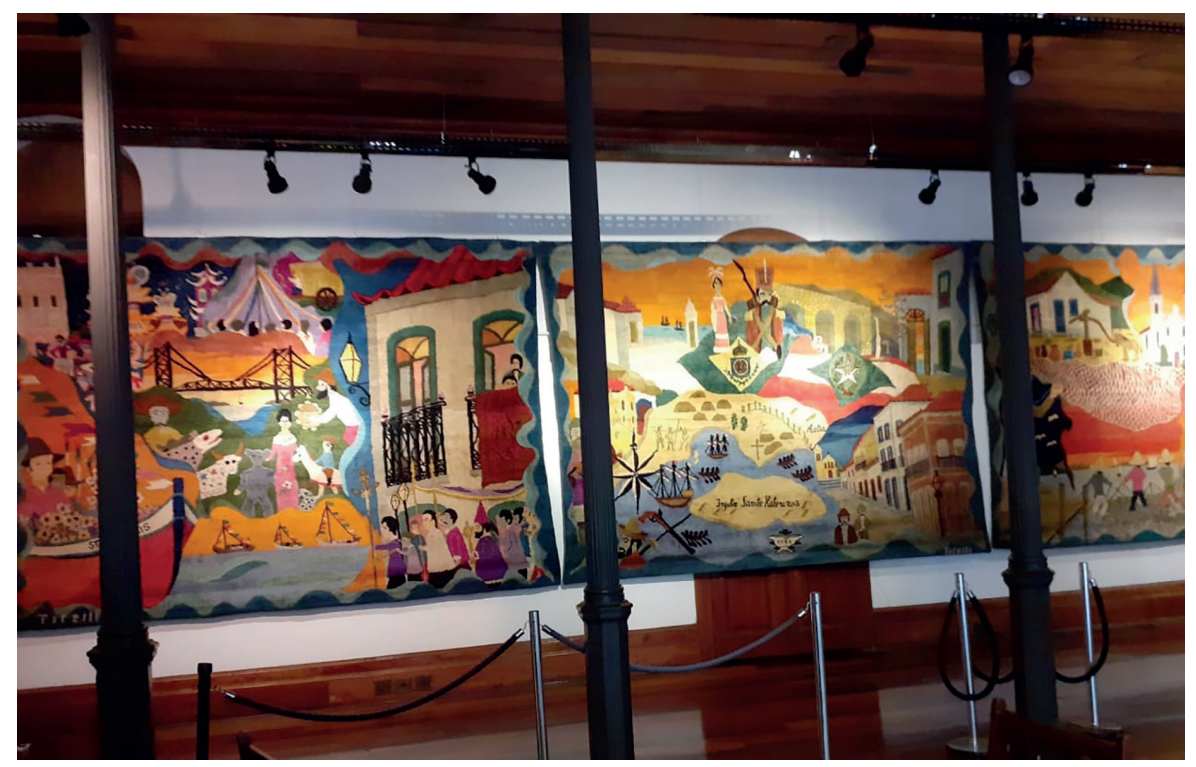

Figura 30 - Montagem no MHSC. Fevereiro/março de 2021. Foto: Lena Peixer Fonte: Fotografia de Lena Peixer.

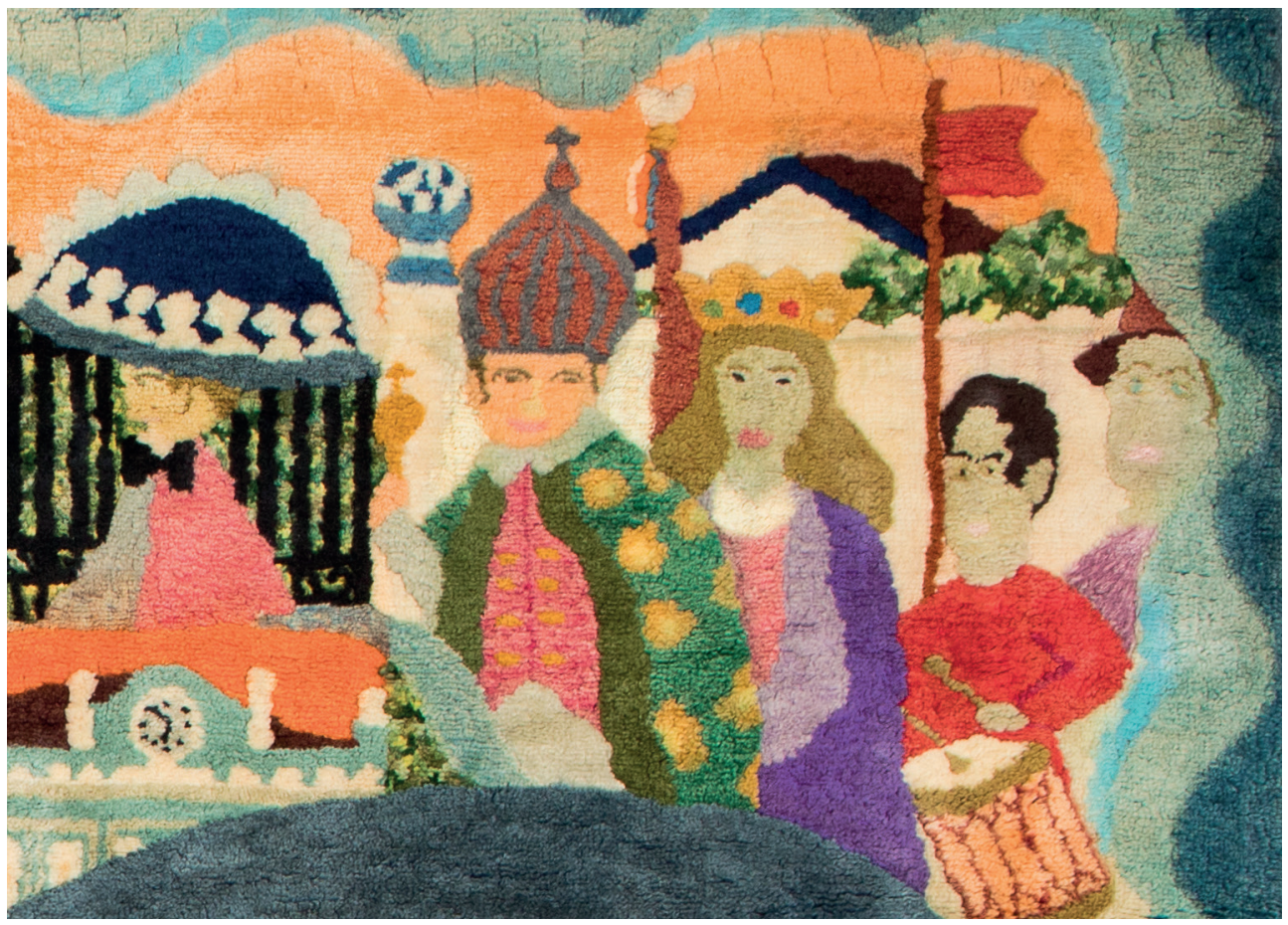

Figura 31 - Detalhe do painel 3. Almir Tirelli Dias. 1974. Tapeçaria em lã. Dimensões: 2,85 m x 3, 85 m. Proprietário: Fundação Catarinense de Cultura. Número de Tombo: 1-0064.7.61 Fonte: Fotografia de Carlos Pontalti. 


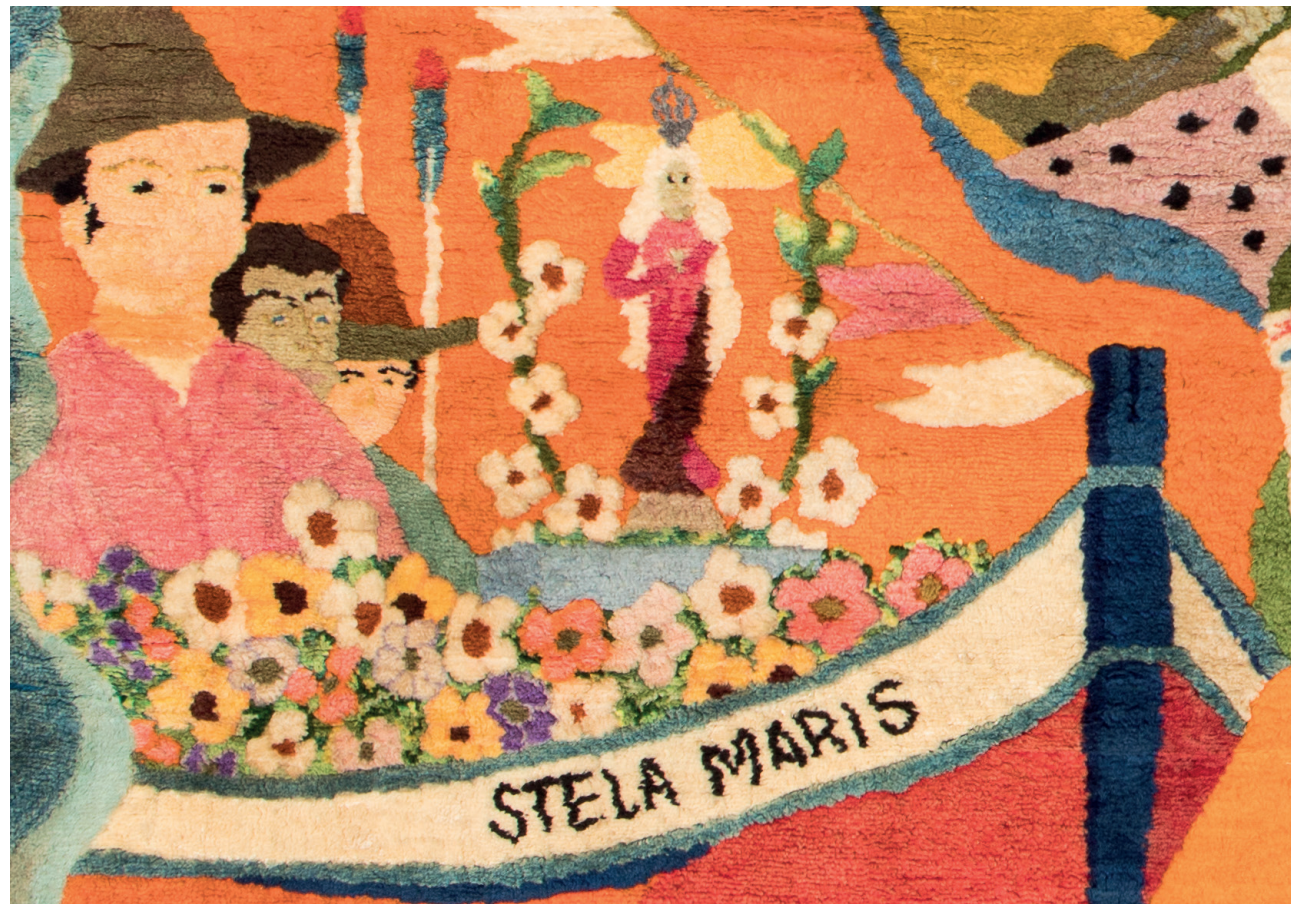

Figura 32 - Detalhe do painel 1. Almir Tirelli Dias. 1974. Tapeçaria em lã. Dimensões: 2,95 m x 4, 05 m. Proprietário: Fundação Catarinense de Cultura. Número de Tombo: 1-0064.7.62 (Patrimônio INFRAERO). Fonte: Fotografia de Carlos Pontalti.

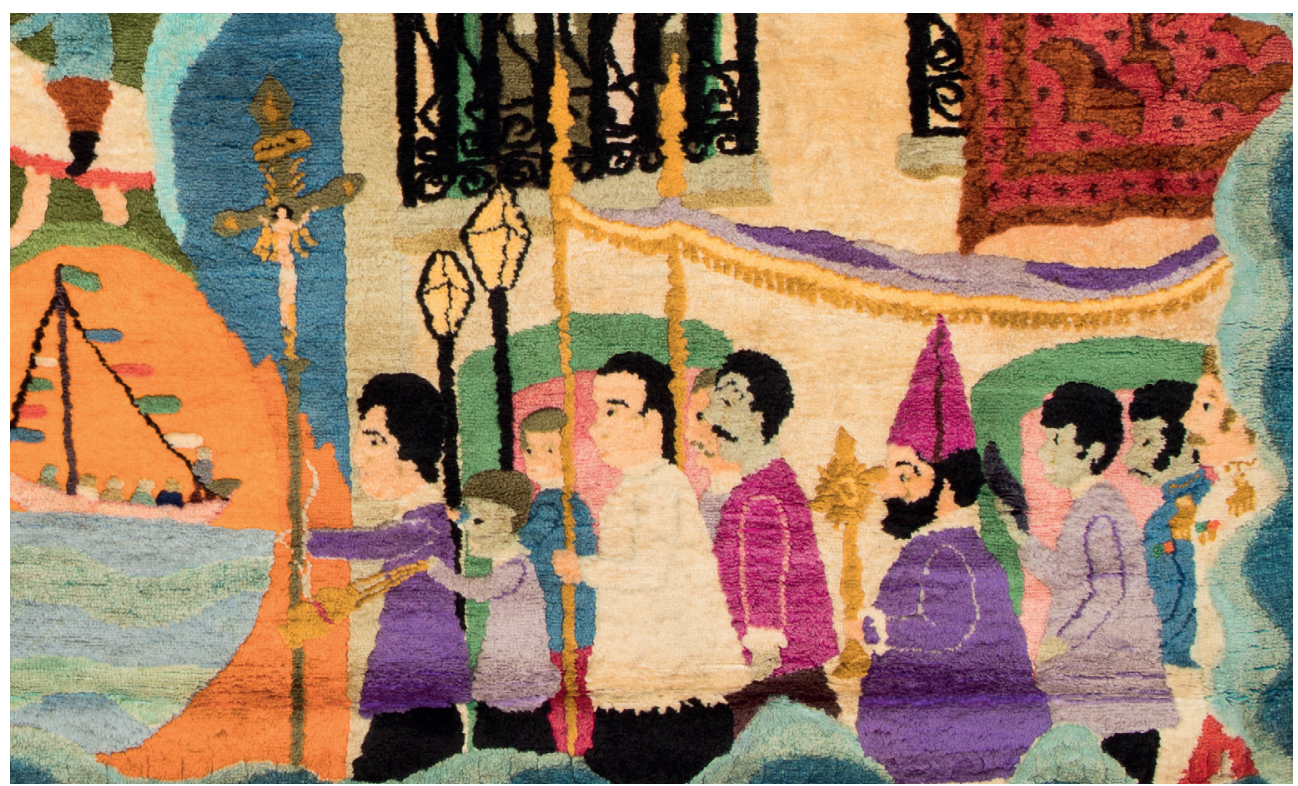

Figura 33 - Detalhe do painel 1. Almir Tirelli Dias. 1974. Tapeçaria em lã. Dimensões: 2,95 m x 4, 05 m. Proprietário: Fundação Catarinense de Cultura. Número de Tombo: 1-0064.7.62. Fonte: Fotografia de Carlos Pontalti. 


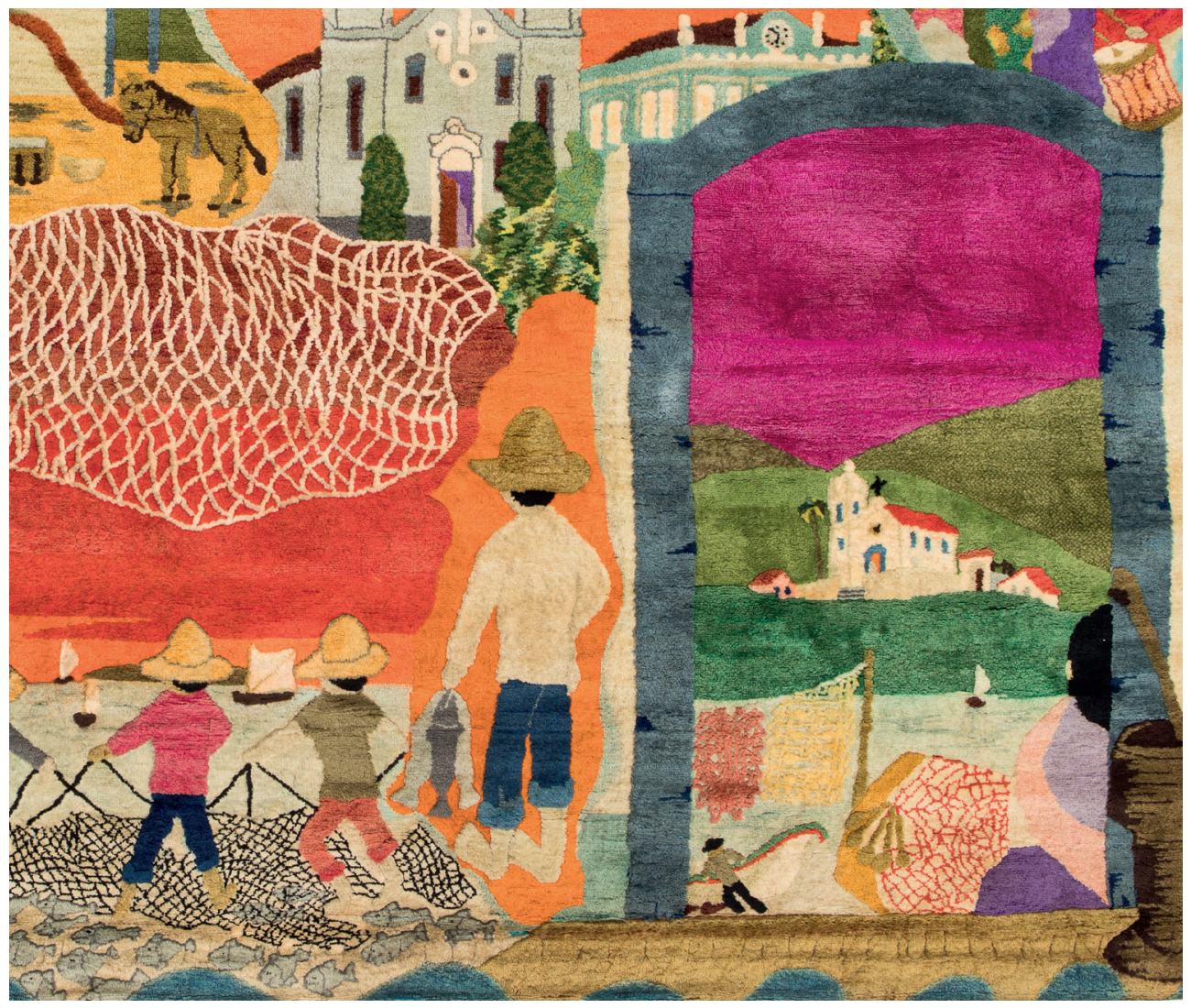

Figura 34 - Detalhe do painel 3. Almir Tirelli Dias. 1974. Tapeçaria em lã. Dimensões: $2,85 \mathrm{~m} \times 3,85 \mathrm{~m}$.

Proprietário: Fundação Catarinense de Cultura. Número de Tombo: 1-0064.7.61 Fonte: Fotografia de Carlos Pontalti. 


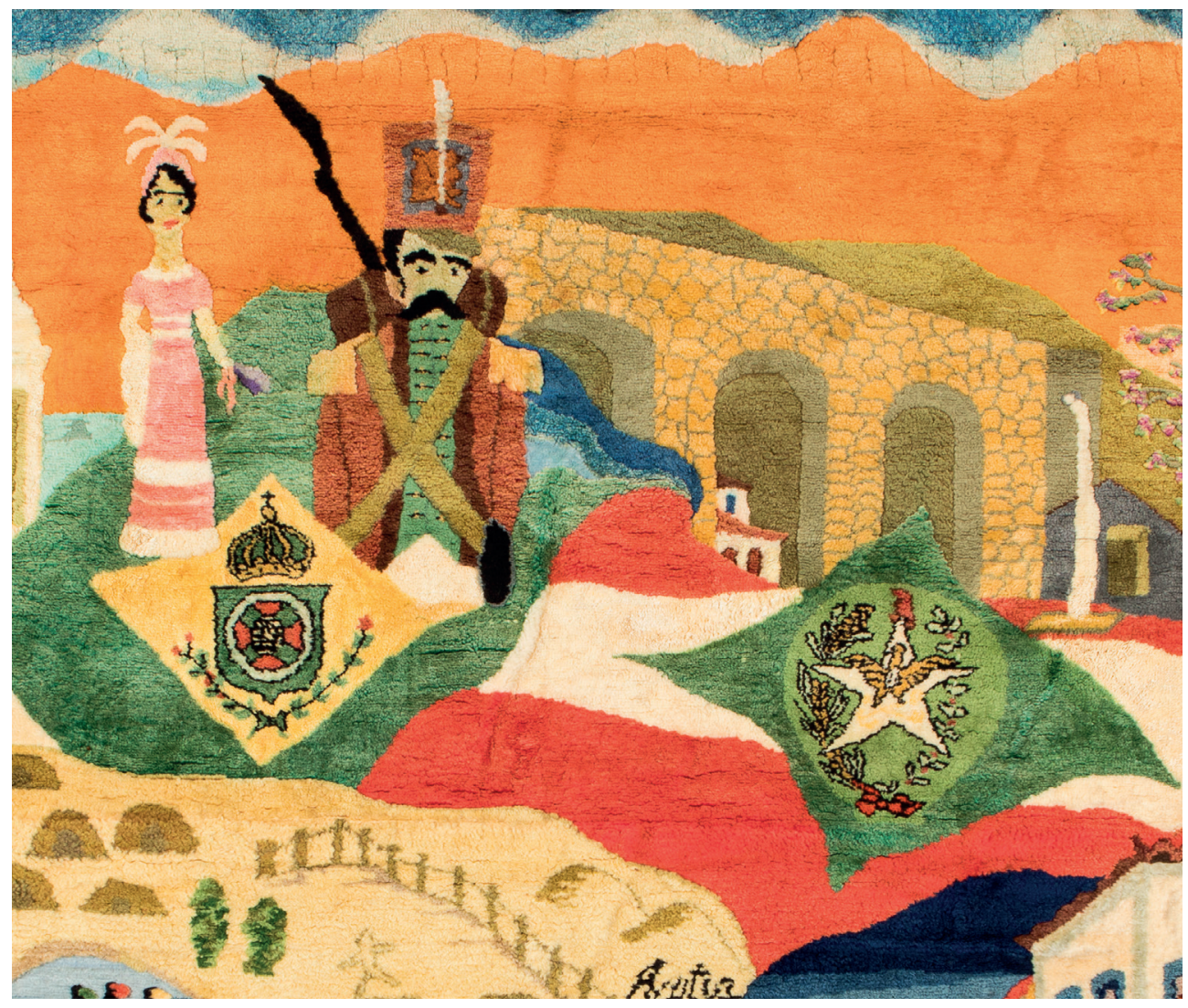

Figura 35 - Detalhe do painel 2 . Almir Tirelli Dias. 1974. Tapeçaria em lã. Dimensões: $2,855 \mathrm{~m} \times 3,85 \mathrm{~m}$.

Proprietário: Fundação Catarinense de Cultura. Número de Tombo: 1-0064.7.60. Fonte: Fotografia de Carlos Pontalti. 


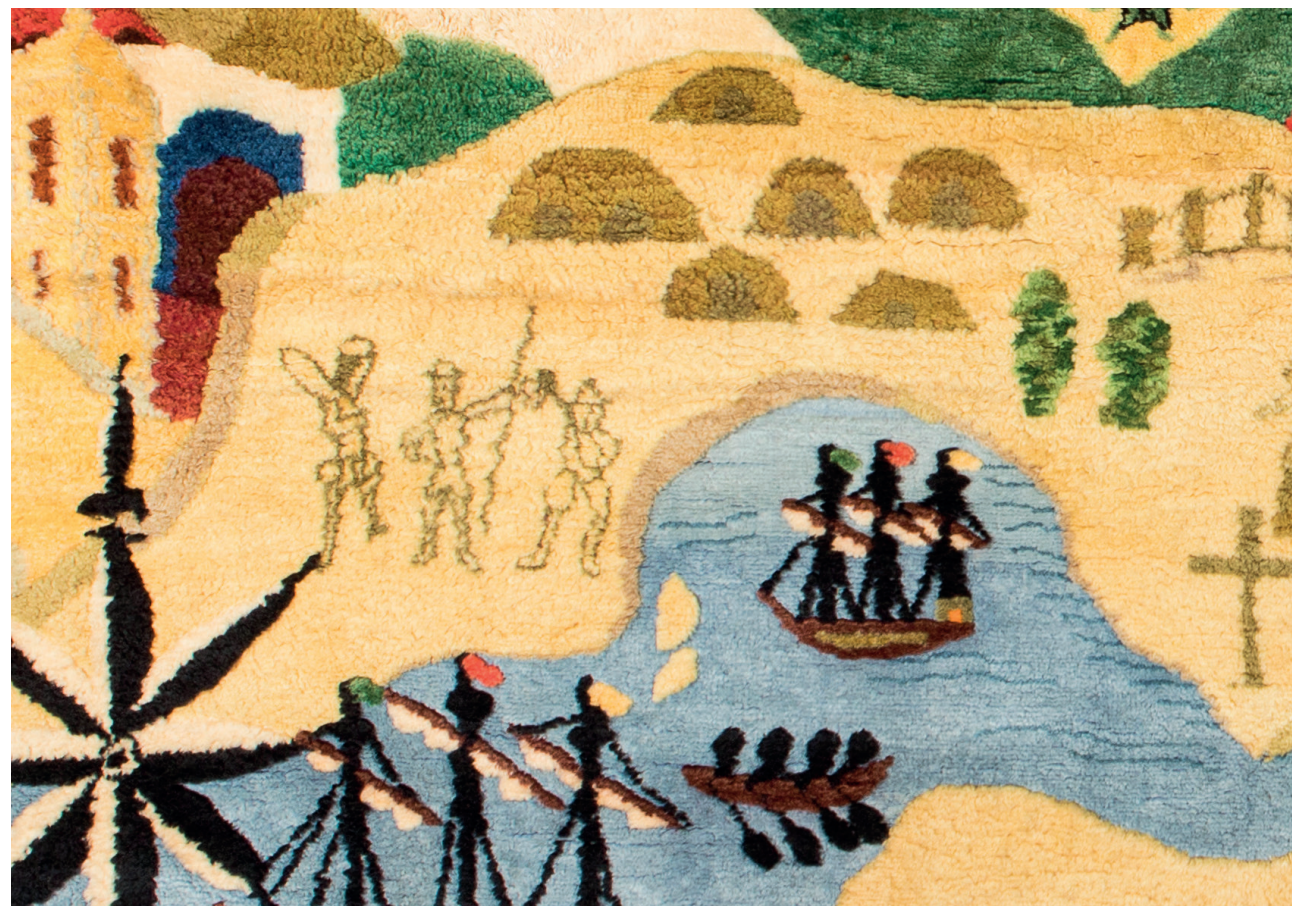

Figura 36 - Detalhe do painel 2. Almir Tirelli Dias. 1974. Tapeçaria em lã. Dimensões: 2,855 m × 3,85 m. Proprietário: Fundação Catarinense de Cultura. Número de Tombo: 1-0064.7.60. Fonte: Fotografia de Carlos Pontalti.

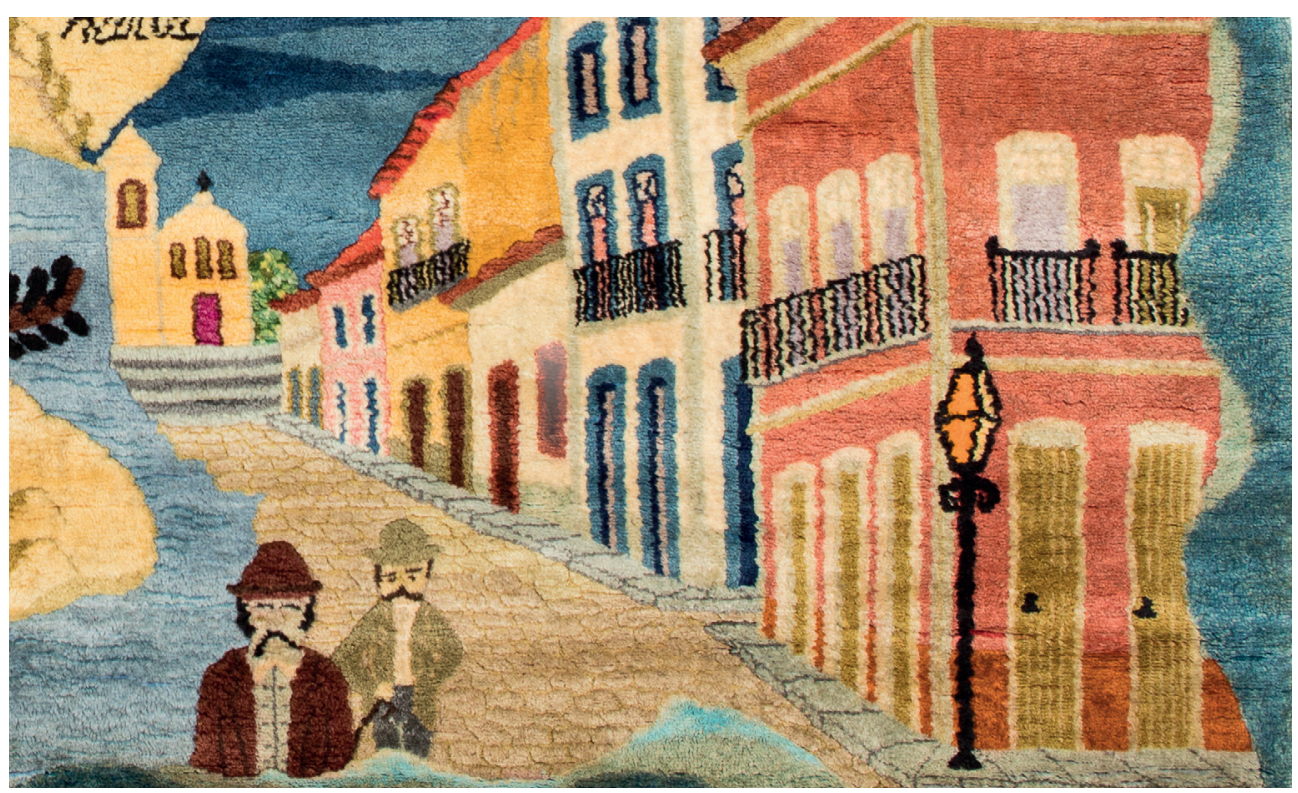

Figura 37 - Detalhe do painel 2. Almir Tirelli Dias. 1974. Tapeçaria em lã. Dimensões: 2,855 m x 3,85 m. Proprietário: Fundação Catarinense de Cultura. Número de Tombo: 1-0064.7.60. Fonte: Fotografia de Carlos Pontalti. 


\section{PARA CONCLUIR E TENTANDO PENSAR EM POSSÍVEIS NOVOS EPISÓDIOS}

Até este momento, o texto traduziu os caminhos de uma trajetória, dividida em episódios. A parte final de conclusão reflete unicamente pensamento da autora, formulada em seu escritório, na chamada "solidão acadêmica". Todavia, ao ler tudo que li, não poderia abster-me de formular possíveis questões, considerando que este é o papel de uma crítica de arte e historiadora da arte, com vasta produção sobre arte produzida em Santa Catarina.

Em arte contemporânea, o termo arte in situ designa um método artístico em que se concebe ou dedica uma obra de arte ao seu local de exposição, pelo que se assume uma característica não transportável dessa obra. In situ qualifica igualmente uma obra que toma em conta o local onde está instalada. No entanto, da mesma forma em que a arte transforma o espaço, o espaço também pode ser um agente transformador da arte. É com essa reflexão que emergem produções artísticas pensadas para um espaço específico, mais conhecidas como instalações site specific. Uma instalação site specific no Brasil é a do artista norte-americano Doug Aitken (2009), em Inhotim (Minas Gerais) (Figura 38). A obra fundamentase em um princípio bastante simples. Trata-se de um pavilhão circular em vidro no qual um furo de 200 metros de profundidade no solo capta o som da terra por meio de microfones. Esse som é transmitido em tempo real, por meio de um sofisticado sistema de equalização e amplificação, que busca uma equivalência entre a experiência auditiva e experiência espacial, no interior de um pavilhão de vidro, vazio e circular. Ou seja, a obra foi pensada para esse lugar (Figuras 38 e 39).

Mas podemos conjecturar que as tapeçarias de Almir Tirelli seriam também site specific? Ou seja, produções artísticas pensadas para um espaço específico? Estaria Almir Tirelli em posição de vanguarda? Vamos recordar o início desta história.

Essa obra, que é patrimônio de Florianópolis e considerada a maior tapeçaria já feita à mão, foi colocada, na década de 70, no saguão do Aeroporto Hercílio Luz, criada exclusivamente para recepcionar os viajantes que chegavam ao aeroporto da cidade, inaugurado em 1976. As peças da obra apresentam elementos do cotidiano ilhéu. E tiveram apoio de 


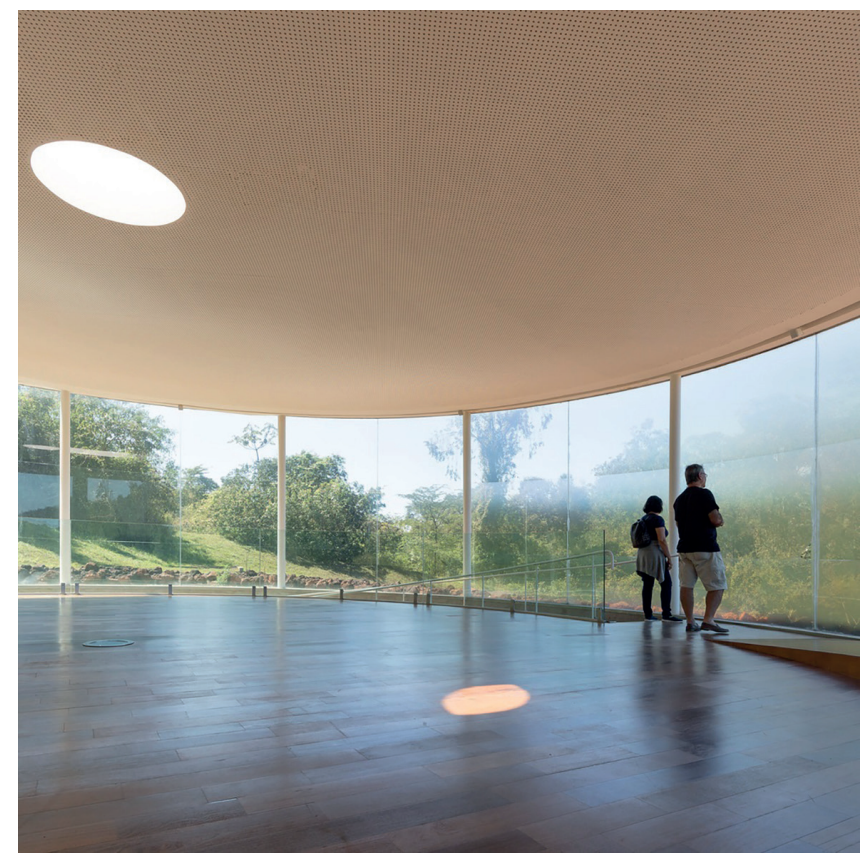

Figura 38 - Doug Aitken. Sonic Pavilion (2009), Inhotim, Minas Gerais, Brasil Fonte: Disponivel em: https://br.pinterest.com/pin/914862412187519/. Acesso em: 10 out. 2019.

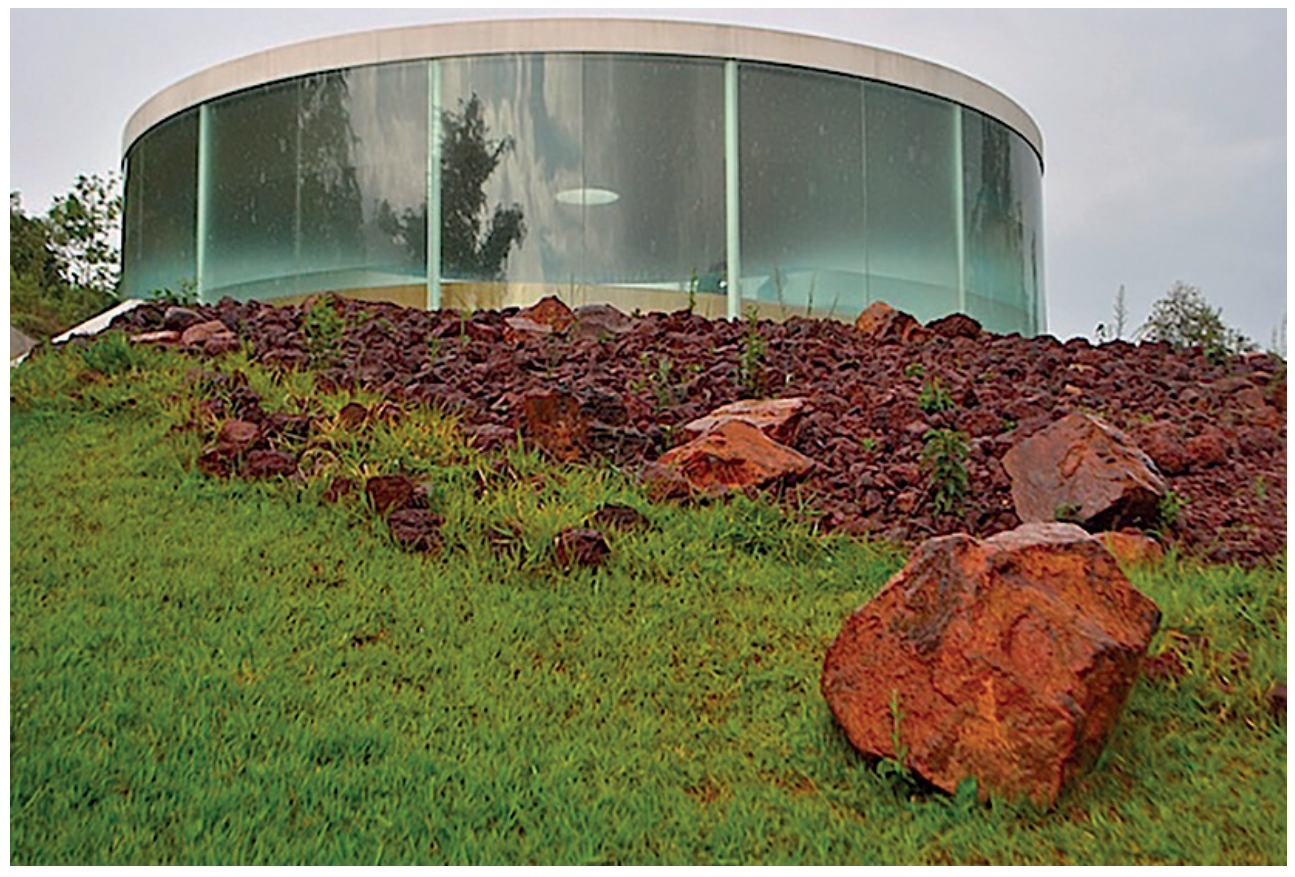

Figura 39 - Doug Aitken. Sonic Pavilion (2009), Inhotim, Minas Gerais, Brasil Fonte: Disponível em: https://br.pinterest.com/pin/914862412187519/. Acesso em: 10 out. 2019. 
mecenas. Elas foram concebidas para aquele local - e entendam, "criada exclusivamente para recepcionar os viajantes que chegavam ao aeroporto da cidade"!

A museologia atual também defende que as obras/objetos/patrimônios/ devem ser mantidos o mais próximo de seus locais de origem ou permanecer no local a que pertencem. Isso é o que faz sentido.

Em reportagem do Jornal Zero Hora de 4 de junho de 2019, Tulio Milman escreve um texto denominado: "Conheça o Lobo que estará no terminal do Salgado Filho", noticiando que a empresa alemã Fraiport prossegue o seu plano de investimentos no aeroporto de Porto Alegre (MILMAN, 2019).

Continuo a pesquisar e deparo-me com matéria sobre o novo aeroporto de Porto Alegre e ocorre-me que fizeram, em 2019, no nosso estado vizinho, o que aqui fizemos em 1976. Os textos consultados sobre o assunto não me permitem precisão sobre as datas de finalização dos sete murais, mas imagens que constam da matéria (sem data) - Aeroporto de Porto Alegre exibe murais de arte - Murais do Aeroporto de Porto Alegre retratam a riqueza da cultura gaúcha - mostram os painéis prontos e instalados (AEROPORTO..., [2019?a]) (Figuras 40 e 41).

Na página do artista Lobo no Wikipédia - chamada Lobo (Artista plastico) (2021), consta a informação de que em 2019, a Fraport, empresa alemã que venceu a licitação para administrar uma das principais portas de entrada do Rio Grande do Sul, Porto Alegre, convida o artista plástico Lobo para pintar sete murais retratando a cultura gaúcha. A primeira fase do novo Aeroporto Salgado Filho foi entregue em 2019. Por fim, uma aba de imagens nesse mesmo texto do Wikipédia (FILE..., 2019) mostra a Figura 39, dizendo que, em agosto do ano de 2019, esse mural já estava instalado no aeroporto. Os textos consultados não me permitem precisão na finalização dos sete murais, mas imagens que constam da matéria (sem data) Aeroporto de Porto Alegre exibe murais de arte - Murais do Aeroporto de Porto Alegre retratam a riqueza da cultura gaúcha - mostram os painéis, dando a entender que todos estão prontos e instalados (AEROPORTO..., [2019?a]).

Vou reproduzir a citada matéria que diz que os murais do Aeroporto de Porto Alegre retratam a riqueza da cultura gaúcha. Diz o texto que o Grupo Fraport opera o aeroporto de Frankfurt, um dos mais movimentados da Alemanha, e mais nove terminais na Europa, Ásia e América do Sul, onde é responsável pelo aeroporto de Lima, no Peru. Entre as novidades que a Fraport prepara para o novo Aeroporto de Porto Alegre, estão a 
maior coleção de pop art do Brasil, expostas permanentemente em um aeroporto brasileiro. São sete painéis encomendados pela empresa alemã ao artista brasileiro Lobo, que é uma referência em pop art.

\section{O artista Lobo no aeroporto de Porto}

As obras do artista Lobo para o aeroporto de Porto Alegre retratam diversos símbolos da cultura da Capital e do Estado.

Na fala do artista, destacamos:

Meu compromisso com esses murais de arte foi criar uma narrativa, um conceito que vai além de ser simplesmente bonito. A arte precisa superar as sensibilidades do espectador. Espero com a minha arte que os visitantes e viajantes possam experimentar informações sobre a riqueza da cultura gaúcha. (LOBO apud AEROPORTO de Porto Alegre..., [2019?b].

Diz ainda a matéria que os novos murais de arte instalados no Aeroporto de Porto Alegre servirão para distrair, divertir e informar sobre a cultura local. Os murais de arte foram todos pintados à mão pelo artista Lobo, com várias camadas de tinta, retratando o Rio Grande do Sul. Estão espalhados por diversas áreas do Aeroporto de Porto Alegre, contendo diversos símbolos juntos da Capital e do Estado. Os murais são interativos, a arquitetura, os hábitos, a fauna, danças típicas, gastronomia, esporte são alguns elementos cujos símbolos estão nos murais. 


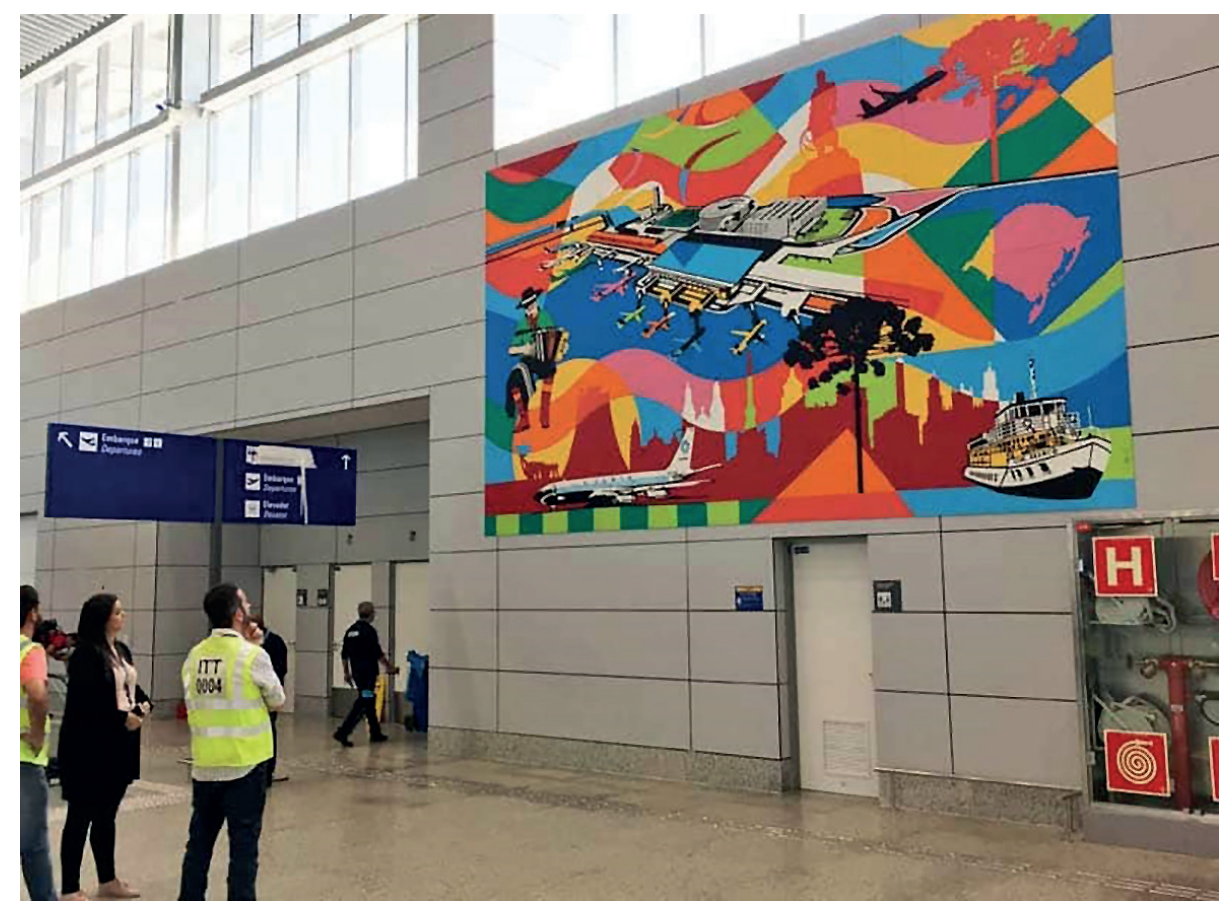

Figura 40 - Obras do artista Lobo, no aeroporto de Porto Alegre Fonte: Disponível em: https://lobopopart.com.br/portfolio/aeroporto-de-porto-alegre/. Acesso em: 22 mar. 2021.

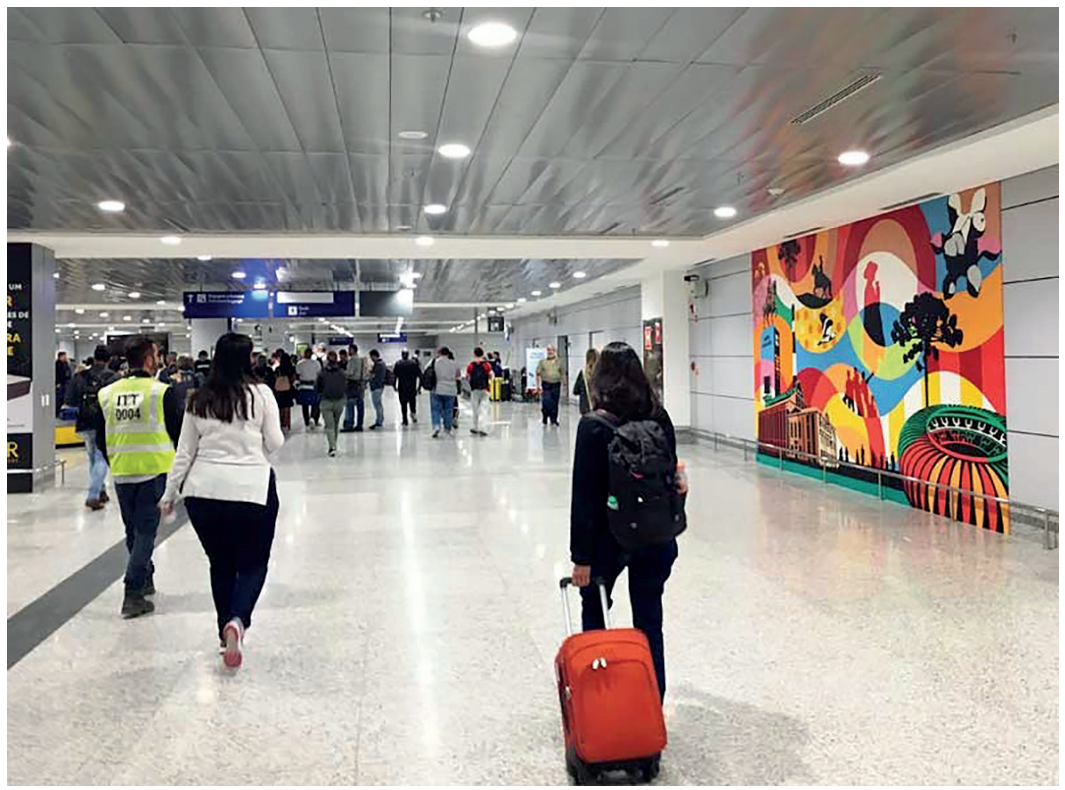

Figura 41 - Obras do artista Lobo, no aeroporto de Porto Alegre.

Fonte: Disponível em: https://lobopopart.com.br/portfolio/aeroporto-de-porto-alegre/. Acesso em: 22 mar. 2021. 
Após ler esse material, eu pergunto. Já não ouvimos essa história antes? Não foi isso que Almir Tirelli fez em 1976? Ou seja, praticamente há 40 anos? O que muda? A técnica? Devo lembrar que a arte expressa-se a cada tempo, no seu tempo, mas as obras de arte são atemporais. São os artistas de uma época que concebem de forma nova a imagem do passado.

Todo presente é infinito e encerra todo o passado que se manteve vivo. A missão da história da arte, se assim podemos dizer, é manter vivo o passado em cada momento, e de descobri-lo com os olhos de cada época. A história da história da arte deve ser entendida como uma evolução, sujeita às condições da época e às diferentes necessidades dos homens, bem como da arte à própria arte.

Para Hegel (2001), se alguma coisa somos no domínio da ciência e da filosofia, devemo-lo à tradição, a qual, através do que perdeu força, e por isso mesmo passado, forma uma corrente sagrada que conserva e transmite tudo quanto o mundo produziu antes de nós. Mas essa tradição não é apenas uma ama que conserva fielmente o patrimônio recebido para mantê-lo e transmitir invariável o que conhece, mas é viva, e continuamente se vai enriquecendo com novas contribuições. Desse modo, aquilo que todas as gerações produziram como ciência, como patrimônio espiritual, constitui uma herança acumulada pelo trabalho de todos os homens que nos precederam. A recepção dessa herança equivale ao exercício da posse dela. Ela forma a alma das sucessivas gerações. Dessa maneira, vai modificando-se o patrimônio herdado, e simultaneamente se enriquece e conserva o material elaborado. Compreender devidamente essa relação permite alcançar como, pelo estudo da história dessa ciência, somos iniciados no conhecimento da própria ciência. No caso, o estudo da história da arte permite alcançar o estudo da arte. Mas a "ditadura do contemporâneo" tem nos afastado demasiado desse pensamento. Pois há certa tendência a exaltar alguns mitos da arte contemporânea, como "a roda acabou de ser inventada", como se a arte contemporânea fosse o que de mais novo existisse, sem ligar para o fato de que tudo o que já foi visto renasce com outra roupagem.

Os painéis do artista Lobo são, em 2021, o que os painéis de Almir Tirelli foram nos anos de 1970. Povo que não compreende isto está fadado à miséria histórica, e viver sem peso do passado é um fardo muito pesado.

O que defendo, finalmente? Que as tapeçarias de Almir Tirelli, patrimônio material do estado de Santa Catarina, de posse da Fundação Catarinense de Cultura, sejam colocadas em contrato de comodato entre a FCC e o Floripa Airport, no novo aeroporto de Florianópolis, cumprindo 
sua vanguarda, sua ideia de um site specific, e siga recebendo os turistas ávidos por cultura, ou despedindo-se deles, com gostinho de saudade.

E que eu possa ainda passar por esse aeroporto, revendo Almir Tirelli, com destino a Paris, para rever as tapeçarias de A Dama e o Unicórnio, que estão no Museu de Cluny, perto da Notre Dame, tapeçarias imemoriais, atemporais, eternas, valorizadas, e que nos fazem lembrar de um país que valoriza sua cultura e entende, e bem, o que Hegel (2021) quis dizer. No Museu de Cluny, vemos parte da Idade Média preservada. Cluny incorpora muitos trabalhos em mármore e em marfim, vitrais medievais, pinturas de diferentes épocas da Idade Média e um grande conjunto de tapeçarias, com destaque para uma série de tapeçarias do século XV, A Dama e o Unicórnio. São seis tapeçarias com a representação de uma dama com um leão e um unicórnio, e uma aia em algumas das cenas. Cinco das tapeçarias representam os sentidos: o tato, o paladar, o olfato, a audição e a visão. Uma sexta tapeçaria tem a presença de todos os personagens e uma barraca com a inscrição Mon Seul Desir (Figura 42). Essa tapeçaria deu origem a uma vasta literatura interpretativa do significado da cena e da inscrição "Meu único desejo", numa tradução literal, esse último interpretado como o amor ou a compreensão, e pode-se dizer, sem qualquer dúvida, que as tapeçarias estão entre as mais famosas do mundo.

As tapeçarias de mais de três metros de altura por três metros de largura (dimensões como as de Tirelli) mostram, em seis cenas, uma nobre acompanhada de um unicórnio, animal mitológico que tem a forma de um cavalo, geralmente branco, com um único chifre em espiral. Estima-se que as tapeçarias tenham sido tecidas por volta de 1500, na transição entre a Idade Média e a Renascença, a pedido da influente família Le Viste, cujo brasão estaria representado. Os modelos teriam sido fornecidos por um artista parisiense. O caráter enigmático, atribuído às tapeçarias, deve-se às inúmeras interpretações dessa obra de arte, harmônica, de cores vibrantes, feita em lã e seda, e repleta de simbologia (POR QUE A DAMA ..., 2019). 


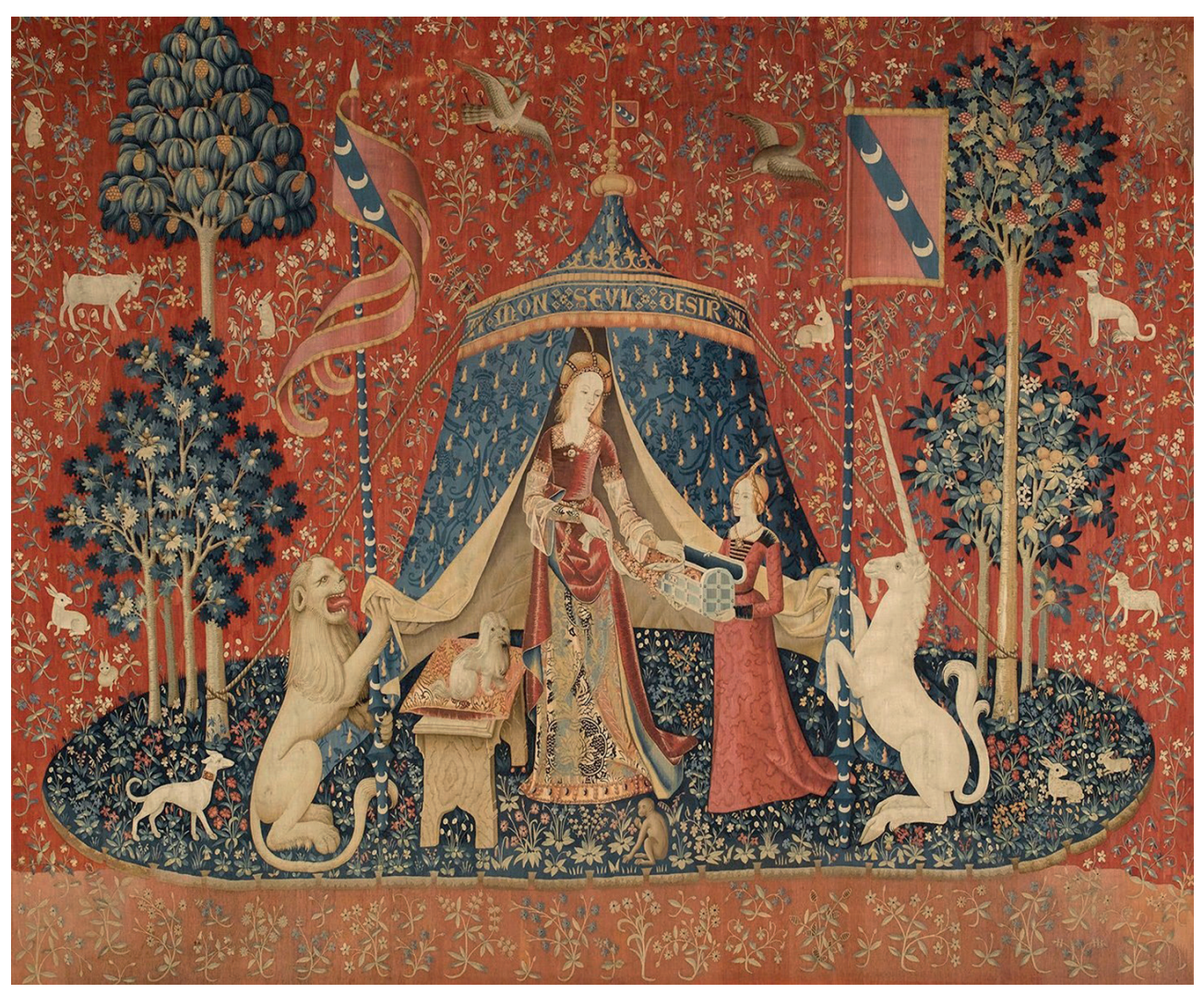

Figura 42 - Tapeçaria da série A dama e o unicórnio- Mon Seul Desir.

Dimensões: 3 × 3 m. Museu de Cluny, Paris, cerca de 1500

Fonte: Disponível em: https://parisdomeujeito.com/2019/07/05/por-que-a-dama-e-ounicornio-do-museu-cluny-despertam-ainda-tanto-misterio/. Acesso em: 22 mar. 2021.

Luiz Marques (2008), em A fábrica do antigo, defende que não é de nosso tempo reificar o "clássico", mas tampouco se trata de incensar o lugar comum, mais recente, de que a modernidade fabrica seus modelos e de que, assim, a Antiguidade não passaria de uma espécie de projeção tautológica de seus legatários. O que o autor ressalta é o fato de que a essência do legado antigo é a contínua problematização da própria noção de legado. Inúmeras são as formas pelas quais uma obra, texto ou pintura, subsiste em outra, fenômeno que se identifica com a própria natureza reticular da criação artística. Contra qualificativos como "novidade" ou "originalidade", o autor reivindica a seleção feliz de expressões de que os escritores antigos nos deixaram o modelo.

As tapeçarias de Almir Tirelli exigem espaços amplos que não possuímos em nossas instituições culturais. Guardar essas tapeçarias é um problema. Expor de forma permanente é outro. Pois elas foram concebidas para ficar no aeroporto, que é enorme e, certamente, dispõe de uma parede para 
recebê-la. As próprias fotos da exposição no MHSC demonstram que os painéis exigem vãos livres para serem observados, e não resta dúvida de que, qualquer que seja seu destino, as tapeçarias deverão ficar protegidas do público, da fumaça, da poeira, da fuligem. Hoje em dia, existem variadas formas de proteção com molduras e caixarias de vidro, acrílicos e outros materiais adequados, necessitando do auxílio de arquitetos para elaborar a melhor solução.

Outra perda significativa, se a obra ficar nas instituições da FCC, é que estará acessível a um público restrito. Que tal comparar com os números de pessoas que transitam nos aeroportos?

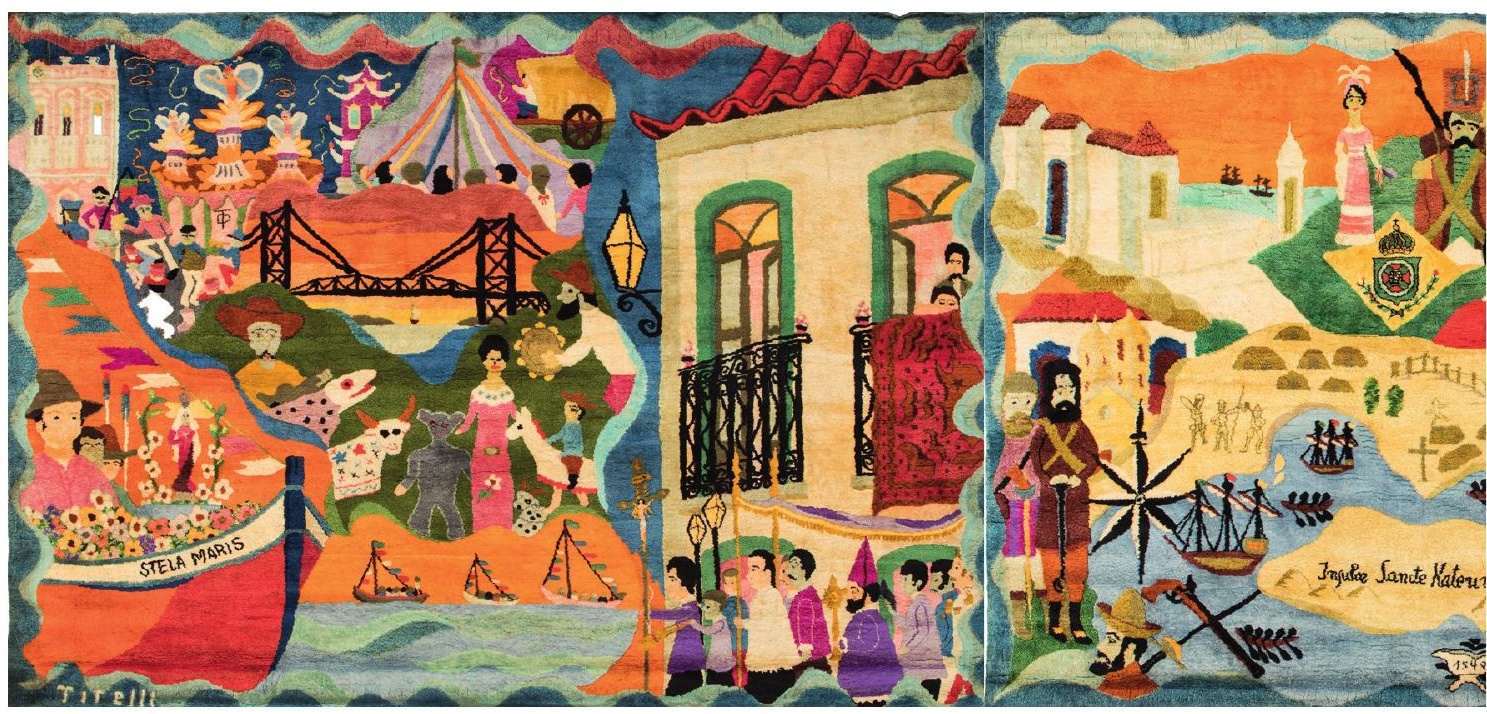

Figura 43 - Montagem dos painéis 1, 2 e 3 respeitando a posição que estavam no aeroporto Hercílio Luz, Almir Tirelli Dias. 1974. Tapeçaria em lã. Proprietário: Fundação Catarinense de Cultura. Número de Tombo: 1-0064.7.62

Fonte: Fotografia de Carlos Pontalti. 
Na sociedade atual, percebe-se uma constante e até avassaladora recusa ao passado, uma ânsia pelo novo, o desejo sem limites pelo contemporâneo, entendido como o aqui e agora. Defende-se, com este texto, a necessidade da compreensão de um sentido de herança e transmissão, considerando que existe um valor particularmente frágil, o da compreensão do mundo humano, que passa pela leitura das obras e de nossos legados e antepassados, incluindo o valor dos clássicos. Assim, pode-se dizer que é preciso legar uma exigência de transmissão e um valor essencial, que é a paixão de compreender. Como lidar com essa questão, entendendo que a obra de arte é uma obra de arte e não um objeto histórico qualquer, em um país vocacionalmente fadado ao moderno e com tantas resistências ao passado, que parece aspirar a um presente eterno e sem memória?

Somos pela volta das tapeçarias de Almir Tirelli (Figura 43) ao aeroporto Hercílio Luz, em sistema de comodato, porque nós sabemos o que significa transmissão e herança.

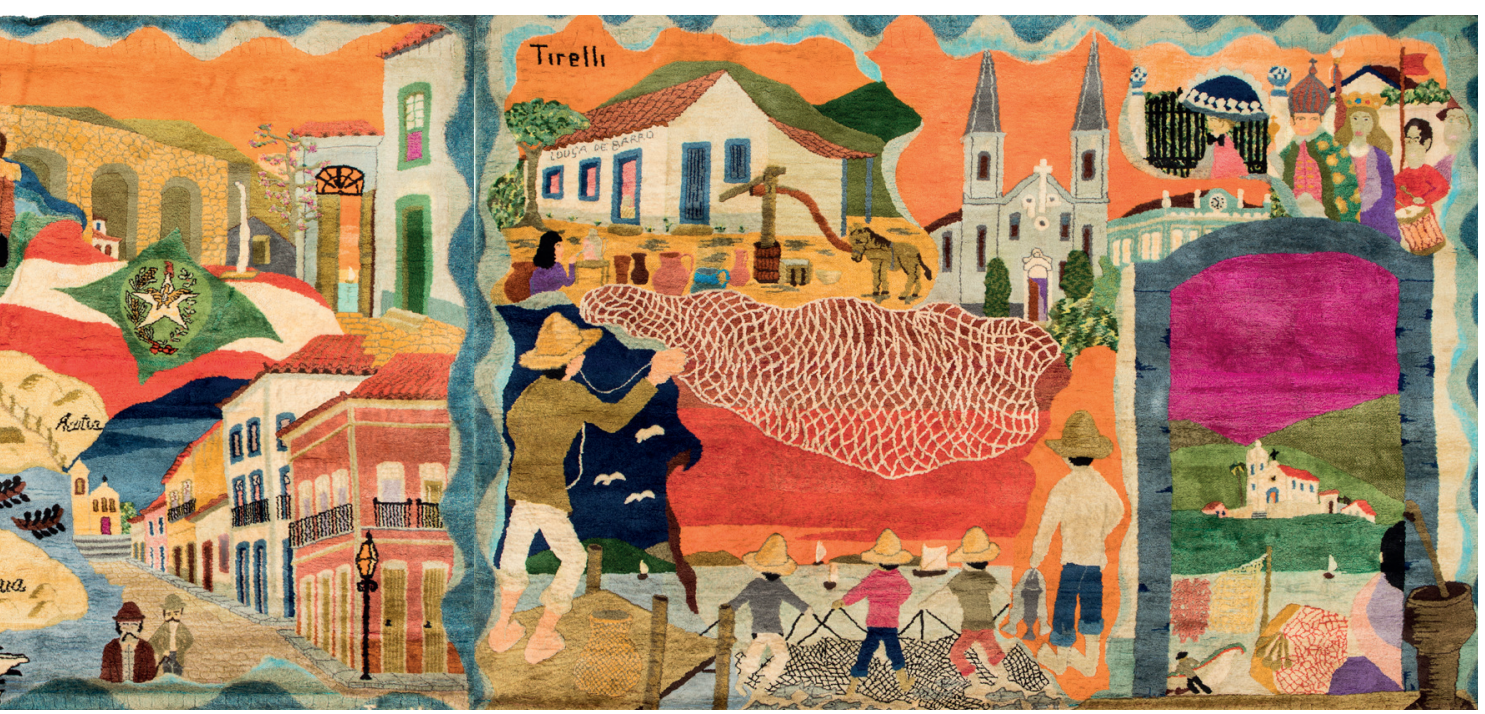




\section{ag}

20. (2)

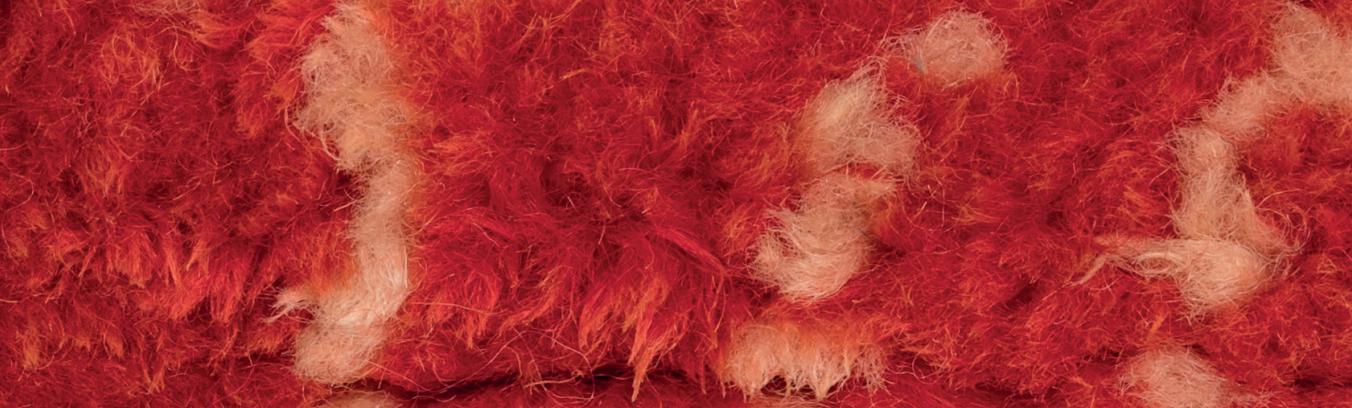

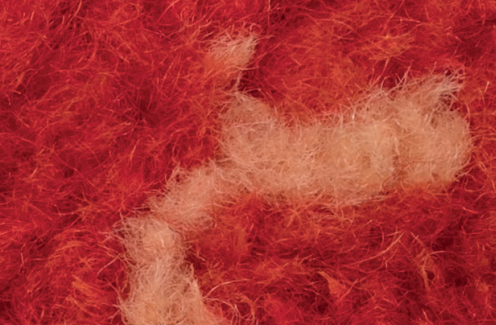





\section{REFERÊNCIAS}

AEROPORTO de Porto Alegre exibe murais de Arte | Lobo Pop Art.[2019?a]. Disponível em: https://lobopopart.com.br/portfolio/aeroporto-de-porto-alegre/. Acesso em: 22 mar. 2021.

AEROPORTO de Porto Alegre exibe murais de Arte | Lobo Pop Art. [2019?b] Disponível em: https://lobopopart.com.br/portfolio/aeroporto-de-porto-alegre/. Acesso em: 22 mar.2021

AEROPORTO INTERNACIONAL HERCÍLIO LUZ. Disponível em: http://www.pmf.sc.gov.br/ entidades/turismo/index.php?cms=aeroporto+internacional+hercilio+luz\&menu=9. Acesso em: 19 mar. 2021.

AITKEN, Doug. "Sonic Pavilion". Inhotim. Brasil, 2009. Disponivel em: https://br.pinterest.com/ pin/914862412187519/. Acesso em: 10 out. 2019.

ANTELO, Raul (org.). João do Rio: alma encantadora das ruas. São Paulo: Companhia das Letras, 1997.

ARENHART, Paulo de. Tirelli, 19 nov. 2019. Facebook Disponível em: https://www.facebook. com/permalink.php?story_fbid=2809751942424265\&id=100001684615119. Acesso em: 17 mar. 2021.

(O) ARTISTA da Concasa e da Rua Caetano Silveira de Mattos. Projeto Memória Palhocense, nov. 2018. Disponível em: https://www.facebook.com/1243554092361701/ posts/2248047825245651/. Acesso em: 10 mar. 2021.

BENJAMIN, WALTER. Passagens. Belo Horizonte: Editora UFMG; São Paulo: Imprensa Oficial do Estado de São Paulo, 2009.

BOTTON, Allain. Nos mínimos detalhes. Rio de Janeiro: Editora Rocco, 2000, p. 95.

CARDOSO. Rafael. A arte brasileira em 25 quadros. Rio de Janeiro Record, 2008.

(O) ESPAÇO para a bandeira. Bom dia. Floripa - São José- Palhoça - Biguaçu - Santo Amaro da Imperatriz, ago. 2018 p. 4. Disponível em: http://www.bomdiafloripa.com.br/Edi\%20050. pdf. Acesso em: 10 mar. 2021.

FLORIPA AIRPORT. Disponível em: https://floripa-airport.com/melhorias-no-terminal-antigo. html. Acesso em: 19 mar. 2021.

FLORIPA ganha novo aeroporto, mas tapeçarias de Tirelli continuam desaparecidas hora de devolver à cidade as tapeçarias de Tirelli. Bom dia. Floripa - São José- Palhoça - 
Biguaçu - Santo Amaro da Imperatriz, ano 6, n. 56, p. 4, set. 2019. Disponível em: http://www. bomdiafloripa.com.br/Edi\%20056.pdf. Acesso em: 10 mar. 2021.

FILE:Artista Lobo Pintura Porto Alegre.jpg. 2019. Disponível em: https://commons.wikimedia. org/wiki/File: Artista_Lobo_Pintura_Porto_Alegre.jpg. Acesso em: 22 mar. 2021.

GROESEN, Michael Van; TISE, Larry E. Theodore de Bry - America - The Complete Plates 1590-1602, editora Taschen, Plate 6, 2020.

HEGEL, Georg Wilhelm Friedrich. A razão na história: uma introdução geral à filosofia da história. São Paulo: Centauro, 2001.

LEVI, Giovanni. Usos da biografia. In: FERREIRA, Marieta de Moraes, AMADO, Janaína (org.). Usos e Abusos da História Oral. Rio de Janeiro: FGV. 2006, p. 167-182.

LOBO (artista plástico). Disponível em: https://pt.wikipedia.org/wiki/Lobo_(artista_plástico) com ultima edição em 9 de abril de 2021. Acesso em: 22 mar.2021.

MAKOWIECKY, SANDRA. Eduardo Dias: Praça XV e a história em símbolos e imagens. In: MAKOWIECKY, Sandra; CHEREM, Rosângela Miranda (org.). Passado-Presente em quadros: uma antologia da história da arte em Santa Catarina. Florianópolis: AAESC - Editora da Associação de Arte Educadores de Santa Catarina, 2019, p. 40-54.

MARQUES, Luiz (org.). A fábrica do antigo. Campinas, SP: Editora da Unicamp, 2008

MILMAN, Tulio. Conheça o Lobo que estará no terminal do Salgado Filho. Jornal Zero Hora, Porto Alegre, 4 jun. 2019. Disponível em: https:/gauchazh.clicrbs.com.br/colunistas/ tulio-milman/noticia/2019/06/conheca-o-lobo-que-estara-no-terminal-do-salgado-filhocjwgqqoc202h801oic3actlow.html. Acesso em: 22 mar. 2021.

NUNES, Lélia. [Onde está e quem se responsabiliza pelo retorno das belas tapeçarias do Tirelli...?]. 8 jul. 2020. Facebook. Disponivel em: https://www.facebook.com/lelia.nunes/ posts/10223872311779718. Acesso em: 18 mar. 2020.

POR QUE A Dama e o Unicórnio (ainda) despertam mistério? 5 jul. 2019 Disponível em: https://parisdomeujeito.com/2019/07/05/por-que-a-dama-e-o-unicornio-do-museu-clunydespertam-ainda-tanto-misterio/. Acesso em: 22 mar. 2021.

STADEN, Hans. Duas viagens ao Brasil. Manaus: Editora Valer, 2020.

SCHWOB, Marcel. Vidas imaginárias. São Paulo: Editora 34, 2004.

SILVEIRA, Nelson. Cortejo do Divino em Santo Antonio de Lisboa. 19 jan. 2021. Facebook. 
Disponível em: https://www.facebook.com/

photo?fbid=3636006366481244\&set=gm.2206192449524445. Acesso em: 20 mar. 2021.

(O) SURFISTA. Disponível em: http://www1.an.com.br/2004/out/24/Osar.htm. Acesso em: 14 out. 2016.

TAPEÇARIA de Almir Tirelli é recolocada na parede do Hercílio Luz. 18 mar. 2010a. Disponível em: http://allehgorie.blogspot.com/2010/03/. Acesso em: 10 mar. 2021.

TAPEÇARIA de Almir Tirelli é recolocada na parede do Aeroporto Hercílio Luz (SC), 17 mar. 2010b. Disponível em: http://desastresaereosnews.blogspot.com/2010/03/tapecaria-de-almirtirelli-e-recolocada.html. Acesso em: 17 mar. 2021.

TAPEÇARIA de Tirelli desapareceu do saguão do aeroporto. Bom dia. Florianópolis - São José- Palhoça - Biguaçu - Santo Amaro da Imperatriz, ano 5, n. 50, p. 3, ago. 2018. Fonte: Disponível em: http://www.bomdiafloripa.com.br/Edi\%20050.pdf. Acesso em: 10 mar. 2021

TAPEÇARIA de Tirelli volta a Santa Catarina após assinatura de termo de doação entre Fundação Catarinense de Cultura e Infraero. 23 out. 2020. Disponível em: https://www. cultura.sc.gov.br/noticias/22798-tapecaria-de-tirelli-volta-a-santa-catarina. Acesso em: 14 mar. 2021.

VIEIRA, Cris. Tapeçaria Tirelli. Destinatário: Sandra Makowiecky. Florianópolis, 18 mar. 2021. E-mail. 2027a.

VIEIRA, Cris. Tapeçaria Tirelli. Destinatário: Sandra Makowiecky. Florianópolis, 22 mar. 2021, e-mail. 2021b. 


\section{ANEXOS}

ANEXO A - Material que pertence aos documentos do MASC referentes à exposição de 1988 denominada "Almir Tirelli, 20 anos de Florianópolis"

ANEXO B - Lei número 9.095, de 20 de maio de 1993, que concede Título de Cidadão Catarinense ao Senhor "Almir Tirelli Dias"

ANEXO C - Ficha diagnóstico do estado de conservação das tapeçarias de Almir Tirelli. Fonte: Marcelo do Amaral - FCC. Ano 2020 


\section{“Almir Tirelli, 20 anos de Florianópolis" - ALMIR TIRELLI DIAS}

Nasceu em 11 de janeiro de 1926, em São Luís - Maranhão. Sendo autodidata iniciou sua carreira artística aos 15 anos desenhando e pintando, e a partir de 1970 iniciou seus trabalhos em tapeçaria no ponto smirna e desenvolveu a técnica em relêvo. Suatemática se baseia na arquitetura do Brasil Coloniale Imperial,folcloreecostumesbrasileiros.

Depois de residir em vários estados do Brasil, fixou-se em Tiradentes - MG, onde seu atellier residência e museu, permanece aberto ao público, com exposição permanente.

Suas tapeçarias decoram, entre outros locais, as Prefeituras de Sidegaura e Aomori, no Japão; Palácio de Queluz em Lisboa, os Palácios Alvorada (Brasília) e Solano Lopes (Paraguai); Palácio do Governo e Palácio da Justiça do Estado de Santa Catarina; Aeroporto da Pampulha, em Belo Horizonte - MG; Aeroporto Hercílio Luz com 36m2, em Florianópolis - SC; Santa SéVaticano - Itália; Banco Mundial de Washington; Universidade Federal de Santa Catarina.

No seu Livro de "Tombo" (registro de seus trabalhos numerados) constam cerca de 1.050 tapeçarias e 1.390 em pinturas-acervos particulares no Brasil e nos seguintes países: França, EUA, Israel (Tel Aviv e Jerusalém), Alemanha, Holanda, Nicarágua, Argentina, Paraguai, Uruguai, Inglaterra, Japão, África do Sul, Malásia e Costa do Marfim. Em viagem de estudos, percorreu Estados Unidos, América Central, e parte da América do Sul e vários países da Europa. Recebeu os seguintes Diplomas e Medalhas: Personalidade do Ano 1978 nas Artes; Troféu Radar; Troféu Cavalo Marinho-Artista da Lagoa; Diploma de Amigo da Marinha (oferecido pelo $5^{\circ}$ Distrito Naval); Diploma de Amigo da Força Aérea Brasileira; Diploma e Medalha no Grau de Cavaleiro das Forças Armadas do Brasil; Medalha de Mérito Santos-Dumont; Medalha e Diploma do Sesquicentenário da Polícia Militar de Santa Catarina; Título de Cidadão Honorário de Florianópolis; Medalha comemorativa da $1^{a}$ Expedição Brasileira à Antartida (oferecimento do Almirante de Esquadra Maximiano da Silva Fonseca); Diplomas dos Escoteiros e APAE de Florianópolis (por serviços prestados). Recebeu na Assembléia Legislativa de Santa Catarina, o título de "Cidadão Catarinense".

\footnotetext{
1 Acervo documental do Museu de Arte de Santa Catarina, MASC, em 9 de março de 2021. Enviado pelo historiador Rodrigo Rosa, da FCC. Mantida a grafia original . Os originais encontram-se no acervo do MASC - Florianópolis. Foram enviados por imagem (fotografia) à autora, a pedido do historiador Rodrigo Rosa, da Fundação Catarinense de Cultura. Foram aqui transcritos pela autora, mantendo-se a grafia original.
} 
Participou de inúmeras exposições:

1970 - Centro de Educação da Universidade Federal de Santa Catarina.

1970 - Clube Paineiras - Florianópolis - SC.

1971 - DEATUR - Departamento de Turismo de Florianópolis - SC.

1971 - Instituto de Educação de Florianópolis - Semana das Artes.

1971 - FAINCO - Feira de Artesanato, indústria e Comércio de Florianópolis - SC.

1971 - Primeiro Encontro regional dos Presidentes de Assembléia - Camburiú - SC.

1971 - Festa das Flores - Joinville - SC.

1972 - III Coletiva Barriga Verde - Blumenau - SC.

1973 - Individual - Assembléia Legislativa de Sta Catarina.

1974 - FEARTE - Feira Nacional de Gramado - RS.

1974 - Individual - Assembléia Legislativa do RS.

1978 - SERTE e DIRETUR - Florianópolis - SC.

1978 - Individual - 5 RM - Comando e $5^{\circ}$ Divisão do Exército - Curitiba - PR.

1981 - Círculo Social Israelita - Individual - Porto Alegra - RS.

1982 - Feirão de 82 - Camburiú - SC.

1986 - Individual - Embaixada do Brasil do Paraguai - Assunção.

1987 - Individual - Livraria Catarinense - Florianópolis - SC.

1987 - Individual - Galeria Eney Santana - São Luís - MA.

1988 - Retrospectiva - 20 anos - MASC - Florianópolis - SC.

1988 - Artistas Catarinenses - Florianópolis - SC.

1989 - Individual - Banco do Brasil - Lagoa - Florianópolis - SC.

1991 - Individual - Exposição e lançamento do Álbum Histórico das Fortalezas da Ilha -

Fortaleza de Santana - Florianópolis - SC.

1993 - Individual - Palácio Cruz e Souza - Florianópolis -SC.

1996 - Restaurante e Galeria Sinhá Moça - Tiradentes - MG.

1997 - Centro dos Artesões da Prefeitura de Tiradentes - MG.

Editou (texto e gravura_álbuns "Fortalezas da Ilha de Santa Catarina" e "História da Lagoa da Conceição" (treis mil volumes esgotados).

Projetou a estátua do "Surfista" na Praia Mole em Florianópolis.

No seu atellier-residência, na Lagoa da Conceição, teve o prazer e a honra de receber inúmeras personalidades nacionais e internacionais como Embaixadores da França, Nicarágua, Costa do Marfim e outras do Corpo Diplomático; D.Pedro Henrique de Orleans e Bragança; artistas como o barítono Jean-Philipp Lafont e Anne Marie Fontaine da Ópera de Paris.

Projeto em andamento para a realização da estátua em homenagem ao alferes Joaquim José da Silva Xavier, na cidade de Tiradentes.

\section{ATELLIÊ-RESIDÊNCIA E MUSEUS: QUINTA DO ALFERES ATELLIÊ TIRELLI.}

Rua Santíssima Trindade, 50 e 70 - Fone (032) 355-1417

Cep: 36.325-000 - Tiradentes MG. 


\section{Almir TIRELLI DIAS}

Dos 597 tapetes já elaborados até julho de 1980, eis alguns locais onde se encontram:

Banco Mundial de Washington - USA

Aeroporto da Pampulha - B. Horizonte

Palácio Queluz - Lisboa-Portugal

Palácio da Alvorada - Brasília-DF

Universidade Federal de Santa Catarina

Aseembléia Lesgislativa de Santa Catarina

Tourist Hotel de Laguna - SC

Hotel Marambaia - Camboriú-SC

Banco do Estado de Santa Catarina - Circiúma-SC

TV Catarinense

$5^{\circ}$ Distrito Naval - Residência do Almirante

Companhia Meditronica - São Paulo

Banco Sul Brasileiro - Ag. Tijucas-RJ

Prefeitura de Sidegaura - Japão

Palácio Solano Lopez - Assunção-Paraguai

Aeroporto Hercílio Luz - Florianópolis-SC

QG da Polícia Militar de Santa Catarina

Palácio da Justiça de Santa Catarina

Banco do Estado de Santa Catarina

Edifício sede da TELESC

Caixa Econômica de Araranguá-SC

Casa do Jornalista de Santa Catarina

Jornal o Estado de Santa Catarina

Edifício Belvedere - Florianópolis

Indústria TEKA - Blumenau-SC 


\section{Almir TIRELLI Dias}

\section{TAPETES EM ACERVOS NO EXTERIOR}

Floris Ansigh - Priss Miritslam, 89 - Haia - Holanda

Nilsen B. Muir - 43 Burten Ave. Montreal - Quebec - Canadá

Harold I. Nemuth - 2012 Monument Ave. - Richmond - Virginia - USA

Eduard Dorremberg - Hamenweb, 7 Hamburg - Alemanha

Elisabeth Fleischauman - Arn Seestern PQB 1133 Dussendorf - Alemanha

Wolf Boemer - 162 Lorind Ave. Murrayfield - Pretoria - África do Sul

Werner A. Golz - 3702 Munich - Alemanha

Antonio Luiz Cinque - Sarmiento, $7671^{\circ}$ Piso - B. Ayres - Argentina

W. Worderwincler - Mercedes Benz - Berlim - Alemanha

Roberto Belagamba - Villate 935 - Olivos - B. Ayres - Argentina

Michel Nadine - 7503 Rue Verginaud - Paris - França

Eduardo Prayones - 195 - Santo Gauto - Assunção - Paraguai

Ministro Saul Gonzales - Ministério da Justiça - Assunção - Paraguai

Carlos Marra Lagoas - Diário La Capital - Rosário - Argentina

Presidente Stsner - Assunção - Paraguai

Norberto Gasquet - Ave. De Los Incas, 3305-B. Ayres - Argentina

Roberto Mell - Calle Maure, 2824 - B. Ayres - Argentina

Construtora Roki S.A. - B. Ayres - Argentina

Alexandro Madero - Calle Paraguai, 946 - B. Ayres - Argentina 


\section{Almir TIRELLI Dias}

\section{TAPETES EM ACERVOS PARTICULARES NO BRASIL}

Presidente João Batista Figueiredo

Mário Henrique Simonsen

Angelo Calmon de Sá

Luci Geisel

Humberto Bastos

Roberto Carlos

Pelé

General Rui de Paula Couto

General Luís Torres Marques

Ayrton Rodrigues

Antonio Carlos Konder Reis

General Florimar Campello

Ministro Said Farah

Roberto Irineu Marinho

Diomício Freitas

Rialdo Guclielmi

Ministro Haroldo Correa de Matos

Lourdes Catão

Almirante Augusto Radmaker

Eduardo Maluf

Osvaldo L. Pires

Aderbal Ramos da Silva

Colombo Machado Salles

Vitor Konder Reis

Douglas Mesquita

Embaixador Pasqual de Carlos Magno

Bernardo Wollffgan Werner

Almirante Marcelo Ramos e Silva

Maurício Sirotsky

Anésio Urbano (S. Amaro Automóveis)

Ephfrain Pinheiro Cabral (Atlântica Boavista)

Wolfgang Andrich (Corpo Consular da Alemanha em S. Paulo)

Nelson Sirotsky 


\section{Retrospectiva - 20 anos de tapeçarias TIRELLI}

Proprietário - Acervo Tirelli

Nome da Obra - Victor Meirelles

Técnica - smirna com revelos

Ano - 1987

Proprietário - Acervo Tirelli

Nome da Obra - Procissão na Rua Felipe Schmidt

Dimensão - 2,88 × 2,00

Técnica - smirna com revelos

Ano - 1987

Proprietário - Acervo Tirelli

Nome da Obra - D. Pedro I

Dimensão - 1,35 × 0,80

Técnica - smirna

Ano- 1975

Proprietário - Acervo Tirelli

Nome da Obra - Grito do Ipiranga

Dimensão - 1,40 x 1,25

Técnica - smirna com revelos

Ano- 1987

Proprietário - Acervo Tirelli

Nome da Obra - Bumba-meu-boi (folclore do Maranhão)

Dimensão - 1,30 × 0,85

Técnica - mixta em pontos baixos

Ano -1977

Proprietário - Acervo Tirelli (Primeiro trabalho - Ano 1968)

Nome da Obra - Catedral de Florianópolis

Dimensão - 0,57 x 0,45

Técnica - meio ponto 


\section{ANEXO B - LEI NÚMERO 9.095, \\ DE 20 DE MAIO DE 1993, QUE CONCEDE TÍTULO DE CIDADÃO CATARINENSE AO SENHOR "ALMIR TIRELL니 DIAS" 2}

LEI № 9.095, de 20 de maio de 1993

Procedência: Julio Garcia
Natureza: PL 084/93
DO: 14.697 de 28/05/93
Fonte: ALESC/Div. Documentação

Concede título de Cidadão Catarinense.

O GOVERNADOR DO ESTADO DE SANTA CATARINA,

Faço saber a todos os habitantes deste Estado que a Assembléia Legislativa decreta e eu sanciono a seguinte Lei:

Art. 1ํ Fica concedido o Título de Cidadão Catarinense ao Senhor "Almir Tirelli

Dias".

Art. $2^{\circ}$ Esta Lei entra em vigor na data de sua publicação.

Art. 3ำ Revogam-se as disposições em contrário.

Florianópolis, 20 de maio de 1993.

\section{VILSON PEDRO KLEINUBING}

Governador do Estado

2 Leis da Assembleia Legislativa do Estado de Santa Catarina. Disponível em: http://leis.alesc.sc.gov.br/ html/1993/9095_1993_Lei.html. Acesso em: 8 mar. 2021. Diário da Assembleia. Disponível em: http://www. alesc.sc.gov.br/diarios/pdf/6886dia.pdf. Acesso em: 8 mar. 2021. 


\section{ANEXO C - FICHA DIAGNÓSTICO DO ESTADO DE CONSERVAÇÃO DAS TAPEÇARIAS DE ALMIR TIRELLI. FONTE: MARCELO DO AMARAL - FCC. ANO $2020^{3}$}

\section{Conteúdo dos anexos nas páginas seguintes.}

3 Enviado por e-mail em documento word por Marcelo do Amaral, da Fundação Catarinense de Cultura, no dia 8 de marco de 2021. AMARAL, Marcelo do. Ficha diagnóstico. Destinatário: Sandra Makowiecky.. Florianópolis, 8 mar. 2021. E-mail. 2021. O documento encontra-se na Fundação Catarinense de Cultura (FCC), DIRETORIA DE PATRIMÔNIO CULTURAL. 
ESTADO DE SANTA CATARINA

SECRETARIA DE ESTADO DE TURISMO CULTURA E ESPORTE

FUNDACÃO CATARINENSE DE CULTURA

DIRETORIA DE PATRIMÔNIO CULTURAL

ATELIÊ DE CONSERVAÇÃO - RESTAURAÇÃO DE BENS CULTURAIS MÓVEIS

Avenida Governador Irineu Bornhausen, 5.600 - CIC- CEP 88025 - 202 - Agronômica -Florianópolis - SC

CGCMF 83.722.462/0001-40 -Fone: (048) 3664-2616 - (48) 3664-2617 - www.fcc.sc.gov.br - atecor@ffcc.sc.gov.br

\section{FICHA DIAGNÓSTICO DO ESTADO DE CONSERVAÇÃO}

\section{IDENTIFICAÇÃO:}

Número de Tombo: 1-0064.0.69 ( Patrimônio INFRAERO )

Termo de doação em andamento.

Título (ou descrição da imagem): Casarios e ruas transversais da Praça XV de novembro ( cercada) Florianópolis.

Autor: Almir Tirelli Dias

Ano: 1975

Técnica:Tapeçaria em lã

Dimensões: $1370 \mathrm{~mm}$ x $1950 \mathrm{~mm}$

Proprietário: Fundação Catarinense de Cultura

\section{FRENTE:}

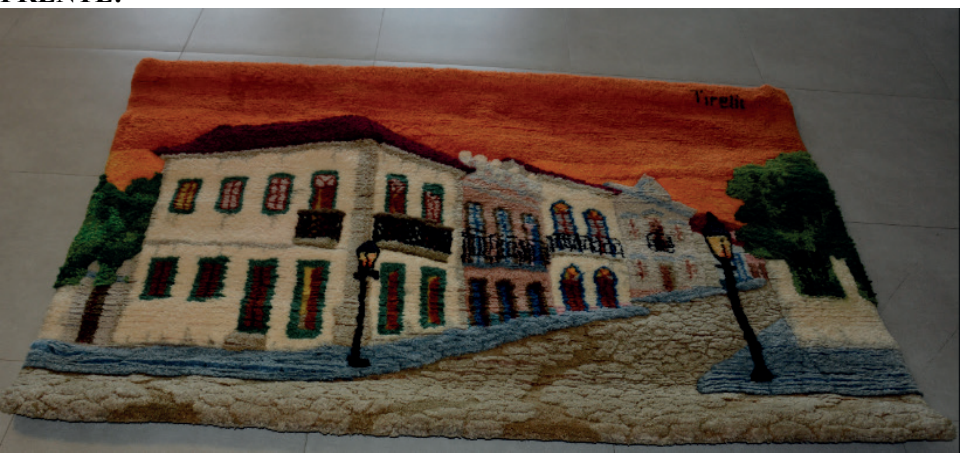

VERSO:

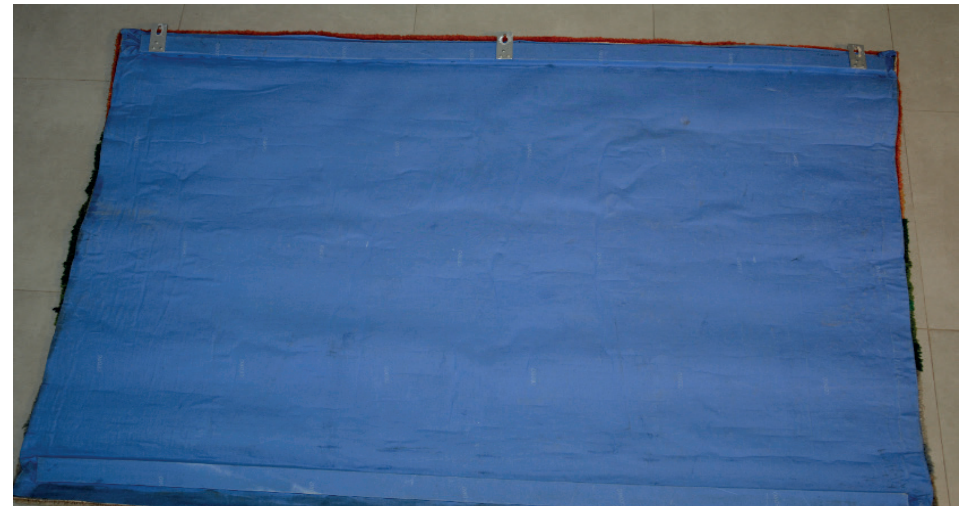


ESTADO DE SANTA CATARINA

SECRETARIA DE ESTADO DE TURISMO CULTURA E ESPORTE

FUNDAÇÃO CATARINENSE DE CULTURA

DIRETORIA DE PATRIMÔNIO CULTURAL

ATELIÊ DE CONSERVAÇÃO - RESTAURAÇÃO DE BENS CULTURAIS MÓVEIS

Avenida Governador Irineu Bornhausen, 5.600 - CIC- CEP 88 025 - 202 - Agronômica -Florianópolis - SC

Número de Tombo: 1-0064.0.71 ( Patrimônio INFRAERO )

Termo de doação em andamento.

Título (ou descrição da imagem): Praça XV- Rio de janeiro - séc. XVIII.

Autor: Almir Tirelli Dias

Ano: 1975

Técnica:Tapeçaria em lã

Dimensões: $1370 \mathrm{~mm}$ x $1950 \mathrm{~mm}$

Proprietário: Fundação Catarinense de Cultura

\section{FRENTE:}

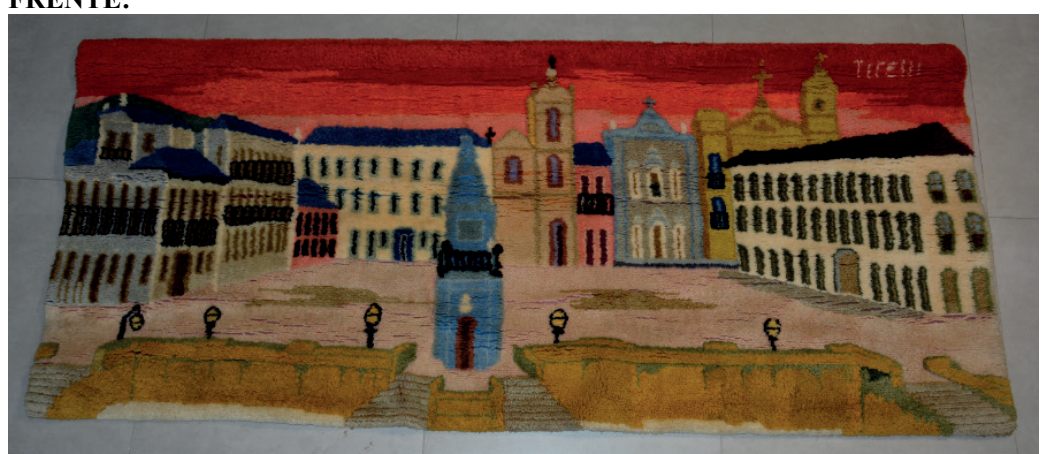

\section{VERSO:}

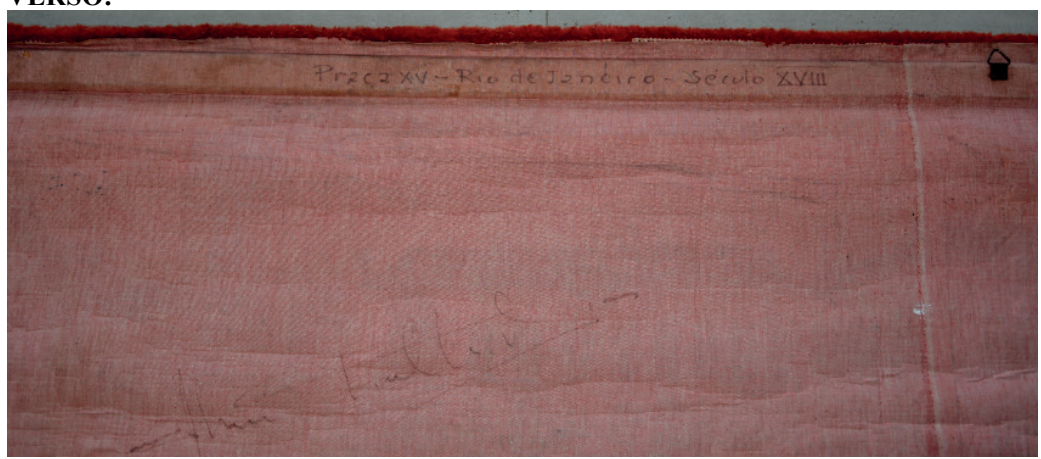


ESTADO DE SANTA CATARINA

SECRETARIA DE ESTADO DE TURISMO CULTURA E ESPORTE

FUNDAÇÃO CATARINENSE DE CULTURA

DIRETORIA DE PATRIMÔNIO CULTURAL

ATELIÊ DE CONSERVAÇÃO - RESTAURAÇÃO DE BENS CULTURAIS MÓVEIS

Avenida Governador Irineu Bornhausen, 5.600 - CIC- CEP 88 025 - 202 - Agronômica -Florianópolis - SC
CGCMF 83.722.462/0001-40 -Fone: (048) 3664-2616- (48) 3664-2617 - www.fcc.sc.gov.br - atecor@fcc.sc.gov.br

Número de Tombo: 1-0064.7.60 ( Patrimônio INFRAERO )

Termo de doação em andamento.

Título (ou descrição da imagem): elementos históricos e arquitetônicos da Ilha de Santa Catarina: Fortaleza de São José da Ponta Grossa, representação do mapa da "Injulce Sancte Katerinia - 1549", com embarcações dos primeiros habitantes e incursões de navegantes colonizadores, Francisco Dias Velho; Bandeiras do Brasil Imperial e de Santa Catarina, Imperatriz Leopoldina, D. Pedro , casarios luso-brasileiros, aqueduto de São Miguel e Casa do Açores

Autor: Almir Tirelli Dias

Ano: 1974

Técnica:Tapeçaria em lã

Dimensões: $2855 \mathrm{~mm}$ x $3850 \mathrm{~mm}$

Proprietário: Fundação Catarinense de Cultura

\section{FRENTE:}

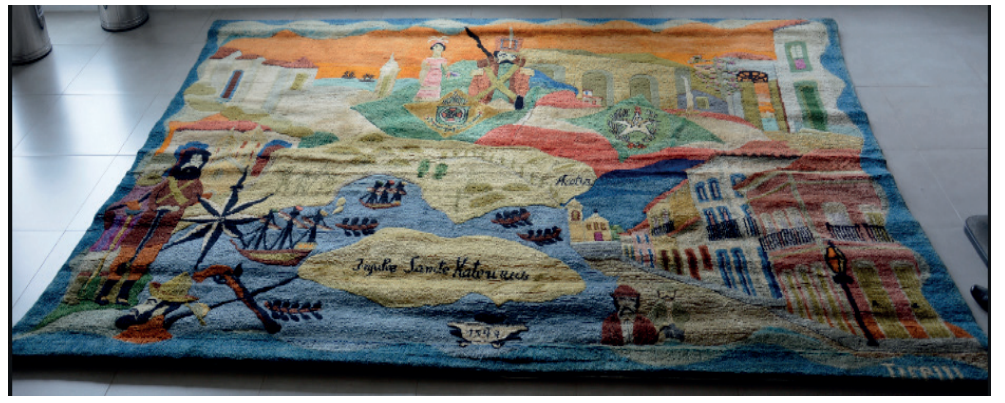

\section{VERSO:}

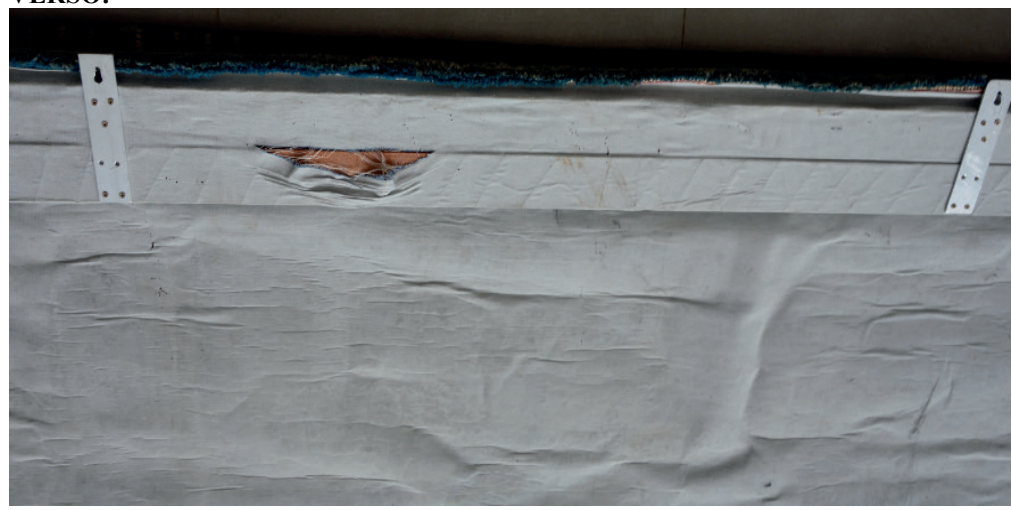


ESTADO DE SANTA CATARINA

SECRETARIA DE ESTADO DE TURISMO CULTURA E ESPORTE

FUNDAÇÃO CATARINENSE DE CULTURA

DIRETORIA DE PATRIMÔNIO CULTURAL

ATELIÊ DE CONSERVAÇÃO - RESTAURAÇ̃̃O DE BENS CULTURAIS MÓVEIS

Avenida Governador Irineu Bornhausen, 5.600 - CIC- CEP 88025 - 202 - Agronômica -Florianópolis - SC

Número de Tombo: 1-0064.7.61 ( Patrimônio INFRAERO )

Termo de doação em andamento.

Título (ou descrição da imagem): arquitetura, elementos do cotidiano e do saber fazer: casa "Louça de Barro" com potes de cerâmica para pegar água no poço-cacimba, pescador jogando tarrafa do trapiche, arrastão da rede na pesca da tainha, Igreja na praça Sete de Setembro - centro de Palhoça, cortejo Imperial da festa do Divino, Igreja de Nossa Senhora da Imaculada Conceição com a vista da rendeira para lagoa da conceição, com suas rendas de bilro.

Autor: Almir Tirelli Dias

Ano: 1974

Técnica: Tapeçaria em lã

Dimensões: $2850 \mathrm{~mm}$ x $3850 \mathrm{~mm}$

Proprietário: Fundação Catarinense de Cultura

\section{FRENTE:}

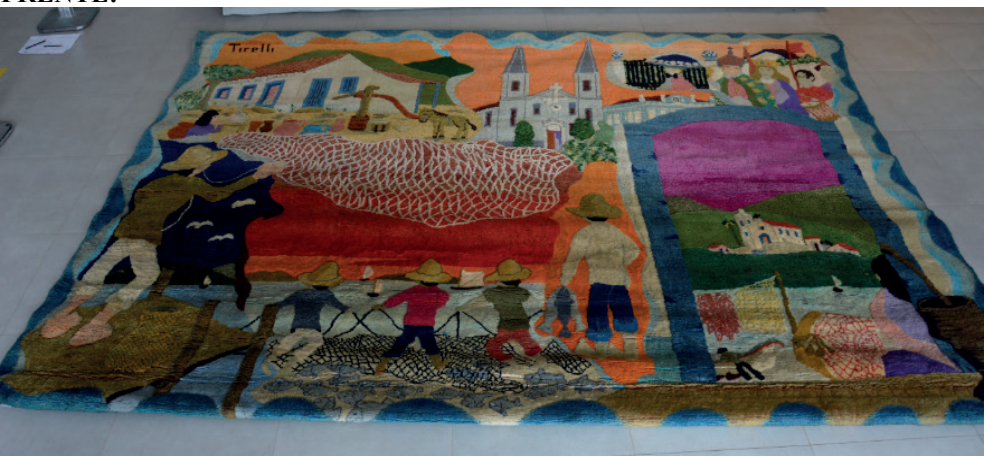

\section{VERSO:}

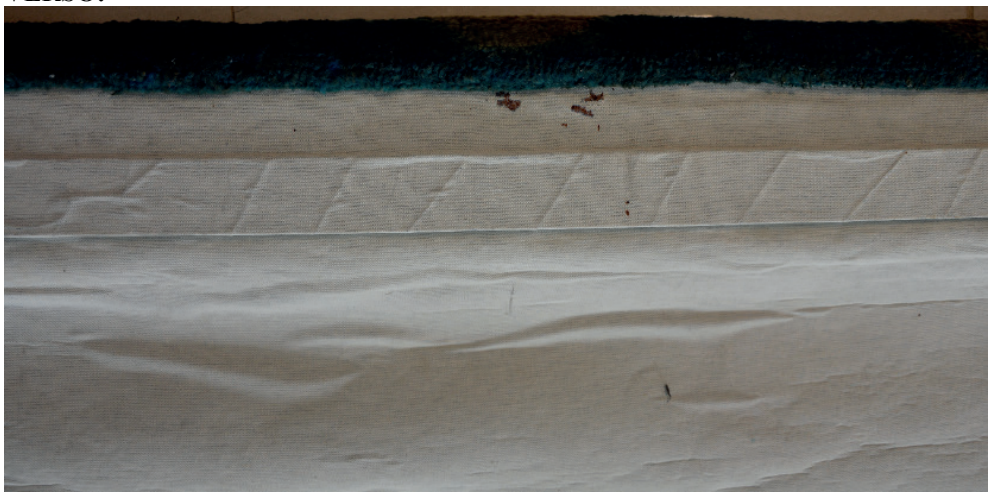




\section{ESTADO DE SANTA CATARINA}

SECRETARIA DE ESTADO DE TURISMO CULTURA E ESPORTE

FUNDAÇÃO CATARINENSE DE CULTURA

DIRETORIA DE PATRIMÔNIO CULTURAL

ATELIÊ DE CONSERVAÇÃO - RESTAURAÇÃO DE BENS CULTURAIS MÓVEIS

Avenida Governador Irineu Bornhausen, 5.600 - CIC- CEP 88025 - 202 - Agronômica -Florianópolis - SC

Número de Tombo: 1-0064.7.62 ( Patrimônio INFRAERO )

Termo de doação em andamento.

Título (ou descrição da imagem): arquitetura, celebrações e tradições relacionadas à cultura da Ilha de Santa Catarina: ponte Hercílio Luz, carnaval de rua, carro alegórico da sociedade carnavalesca Tenentes do Diabo, procissão de Nossa Senhora dos Navegantes na embarcação “Stela Maris", procissão Nosso Senhor dos Passos, Boi de mamão e Pau-de-Fita.

Autor: Almir Tirelli Dias

Ano: 1974

Técnica:Tapeçaria em lã

Dimensões: $2950 \mathrm{~mm}$ x $4050 \mathrm{~mm}$

Proprietário: Fundação Catarinense de Cultura

\section{FRENTE:}

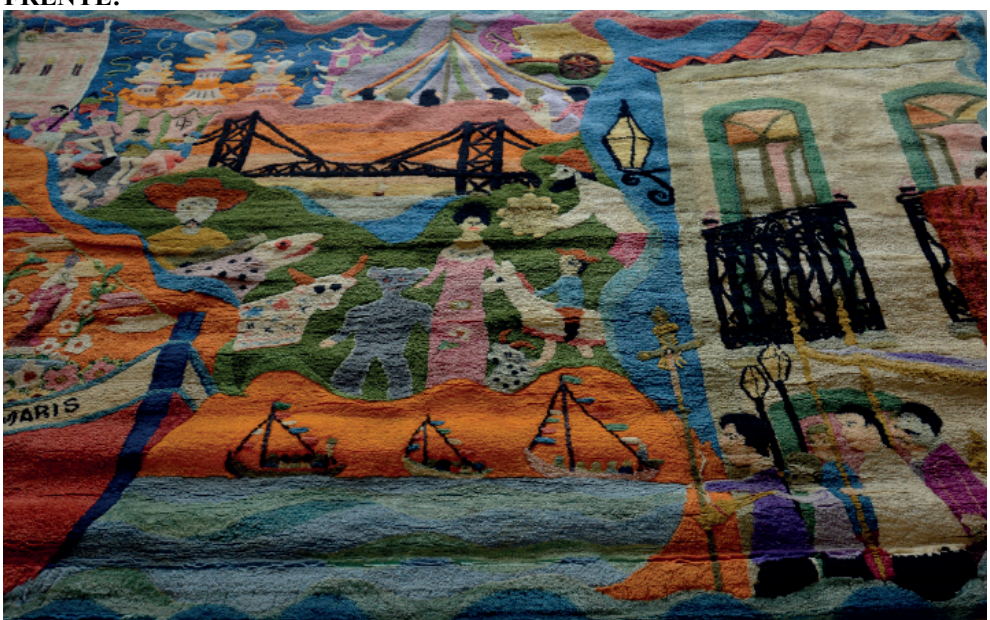

VERSO:

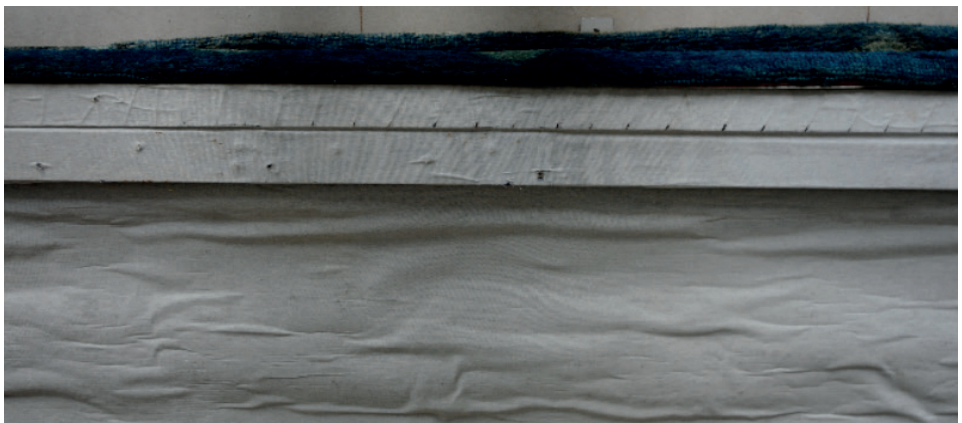



O ocaso e o acaso da vida e obra de Tirelli em Santa Catarina Sandra Makowiecky

Florianópolis, Santa Catarina, 2021. 


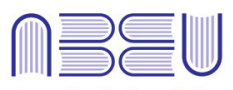

EDITORA

Associação Brasileira 


왕

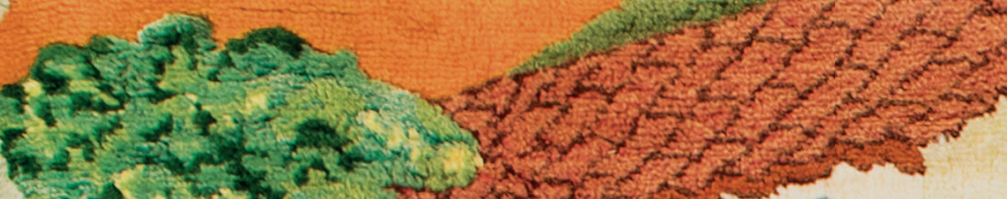

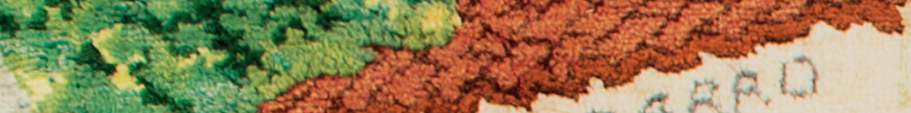

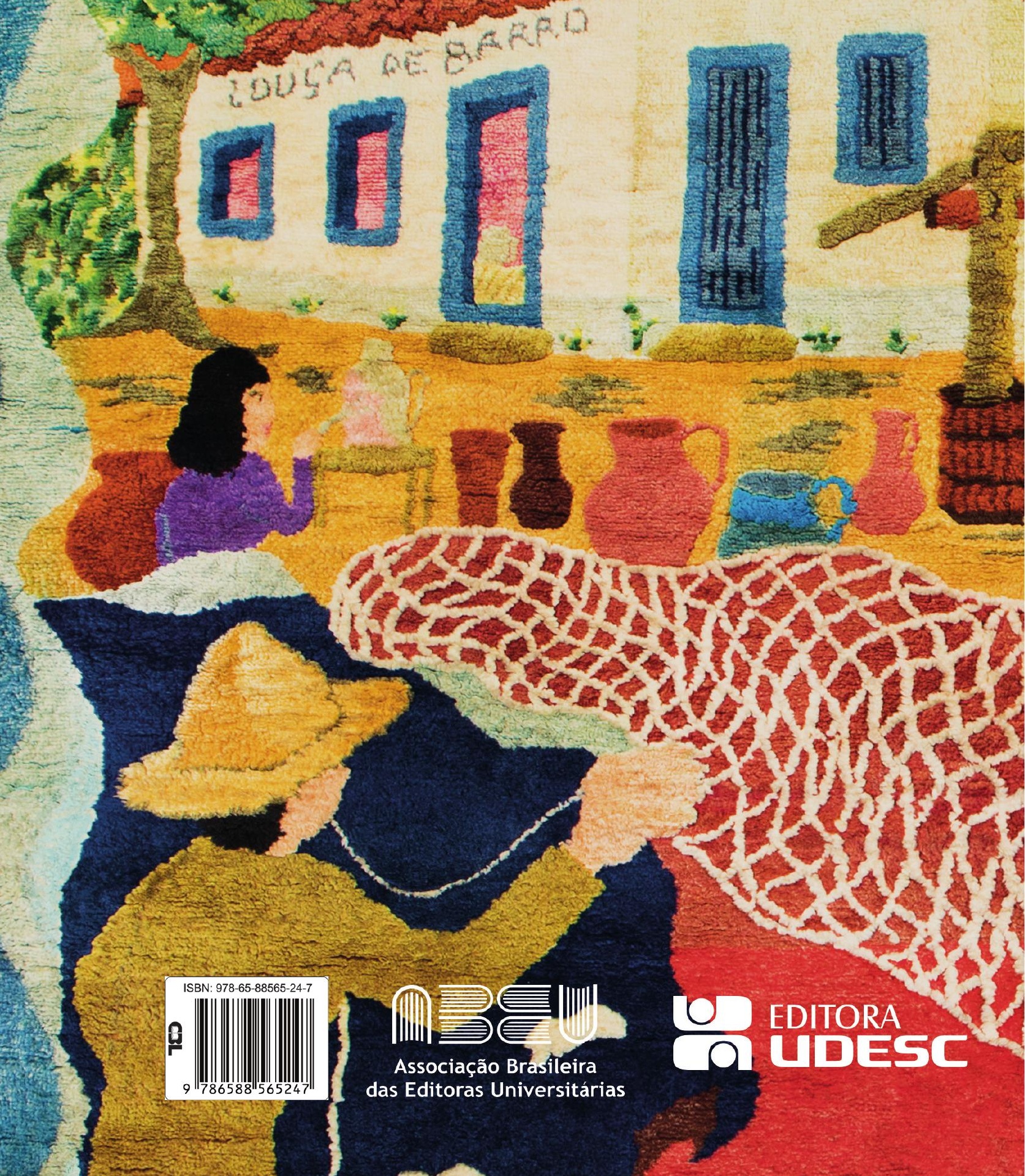

